\title{
SOME ISSUES ON THE EDITIONS OF HORQIN'S EPIC
}

Abstract. The Horqin area in eastern Inner Mongolia is one of the important centers for the formation and development of Mongolian heroic epics. The Kerqin epics not only have the traditional characteristics of all Mongolian epics, but also have local characteristics. In China, the collection and publication of Korqin's epics began in the 1950s. The earliest recorded and edited epic poem "The Story of Suppression of Manggusi" performed by Aozhgrad was published by Inner Mongolia Literature in 1956 Issues 1 and 2. So far, a total of 32 printed copies of 14 "Korqin Epic" have been compiled and published. Most of these printed texts were published in the 1980s and have been published multiple times in the same epic. After 1994, the collection and publication of Horqin's epics was almost stagnant. Until the collection and publication of Horqin's epics in the 21 st century, there were 3 printed texts.

The advent of these achievements has provided abundant basic materials and convenient conditions for the literary and academic circles to understand and study the Horqin epic. However, most of these "Korqin Epic" printed editions are literary works for readers to read through the artificial reduction and adaptation of record organizers and publishers.

Keywords: Horqin epos, publication of an epic, epic edition, traditional and local characteristics
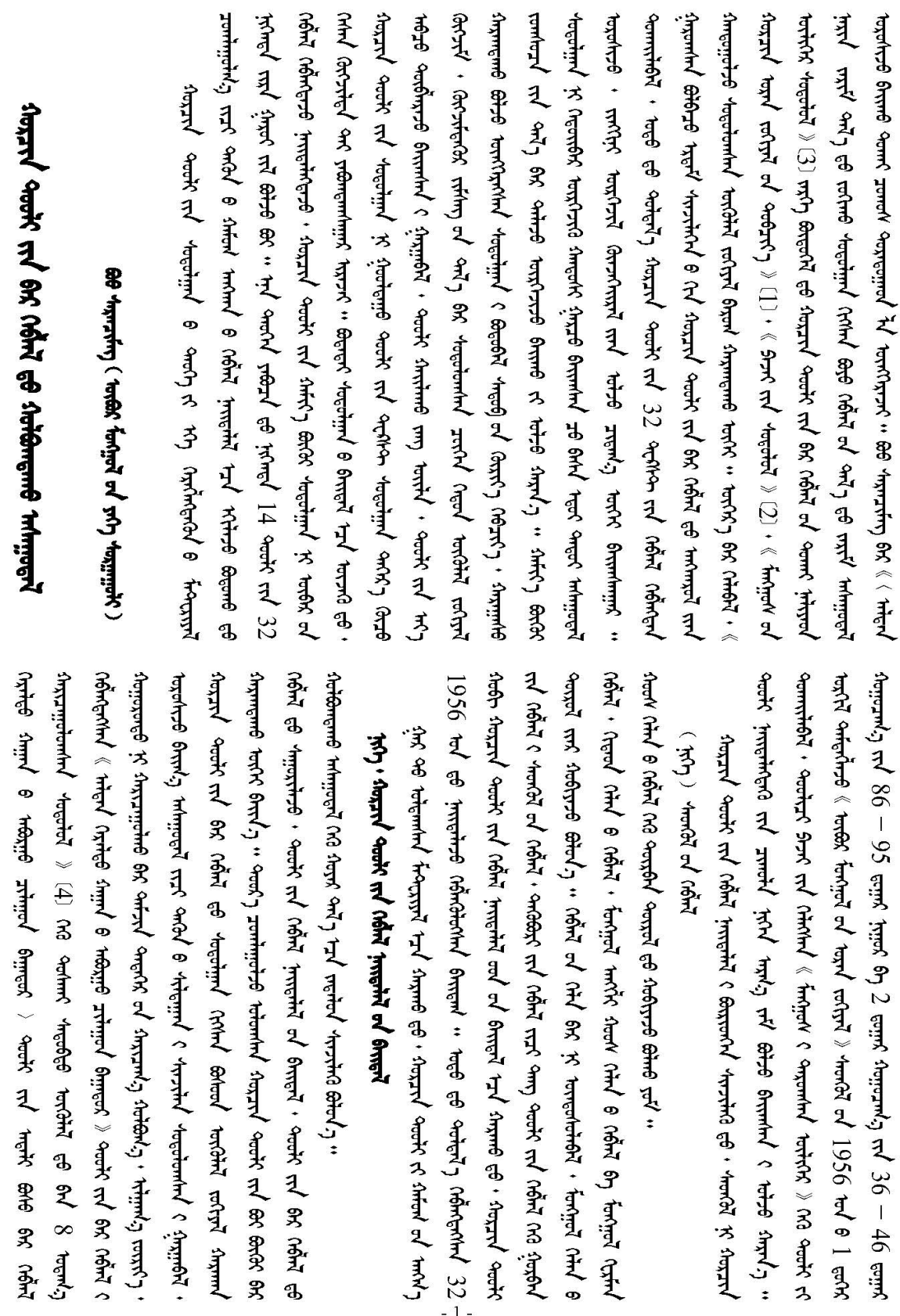


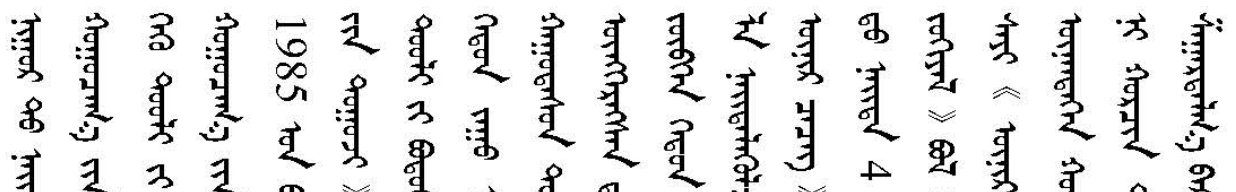

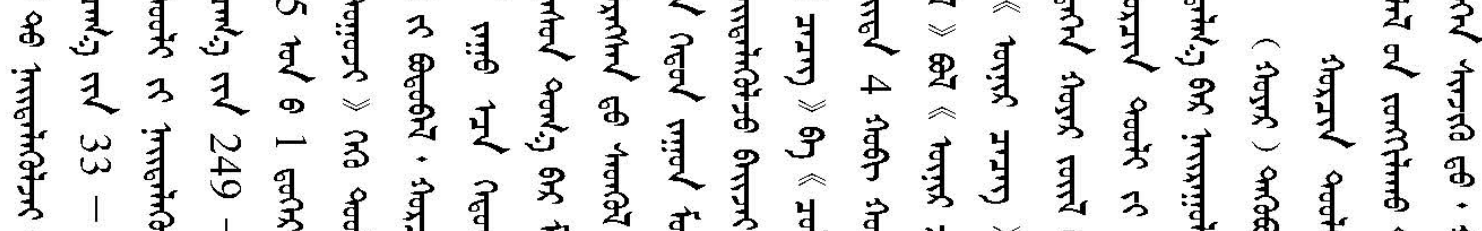

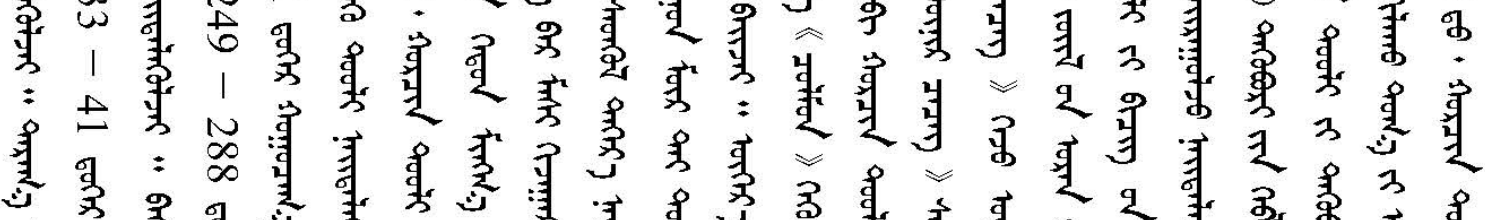

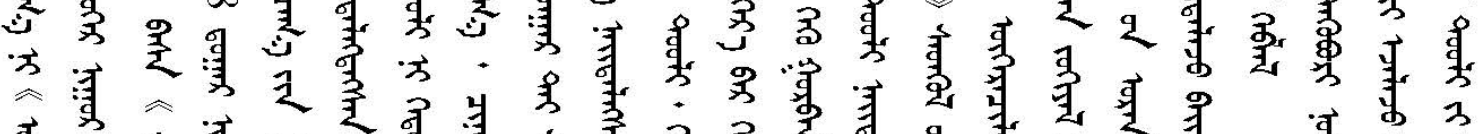

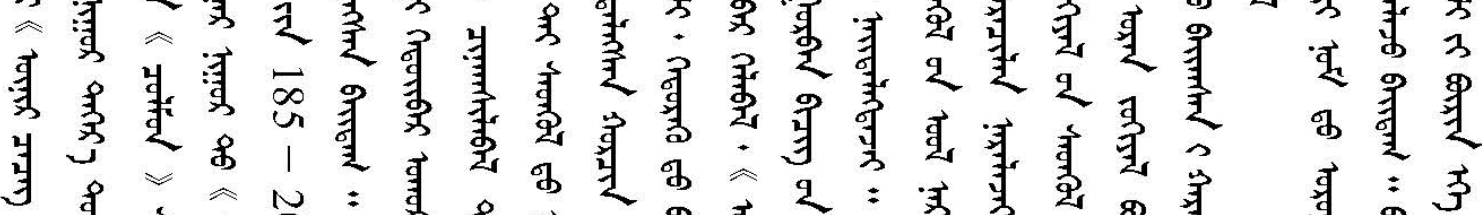

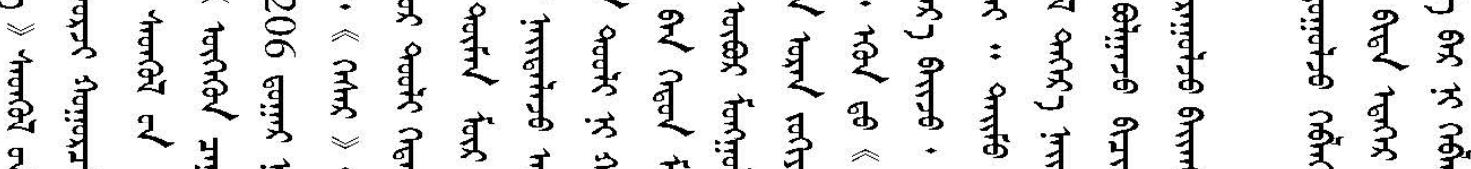

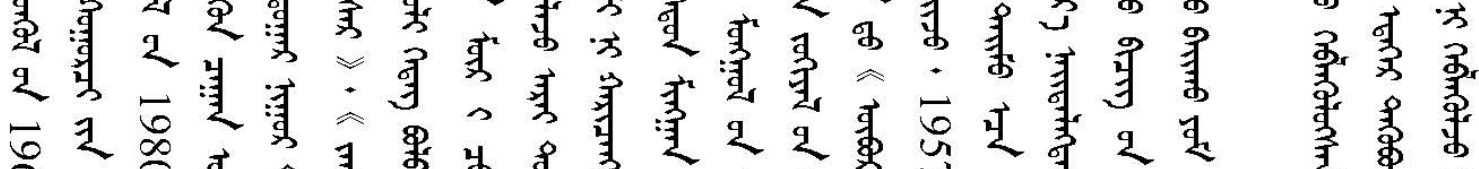

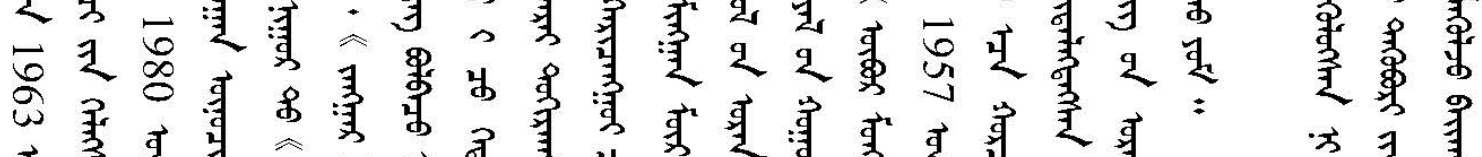

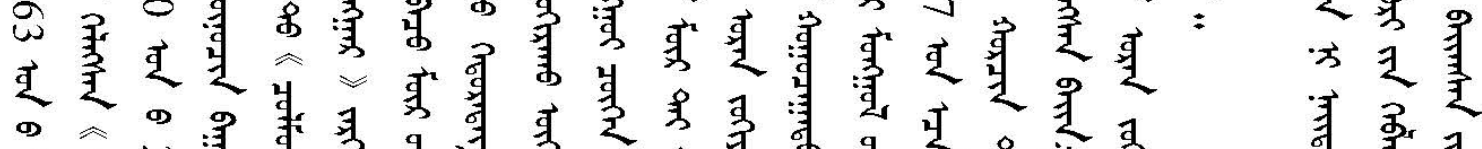

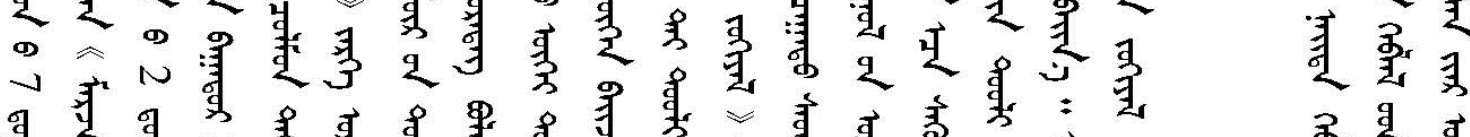

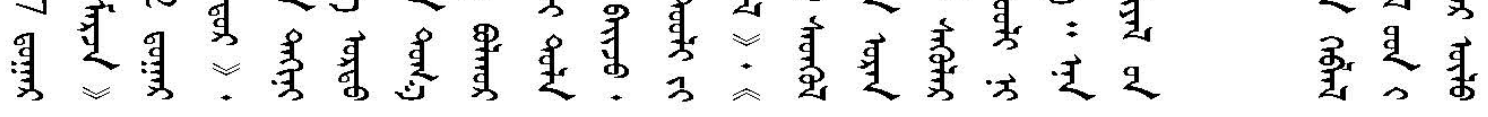

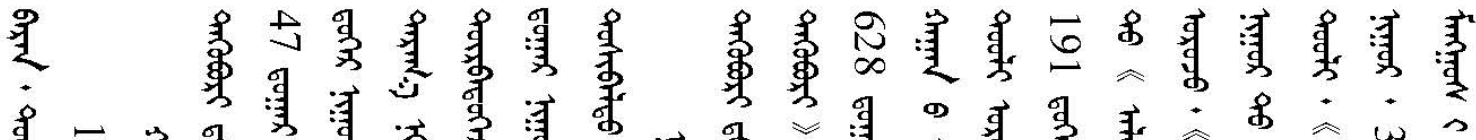

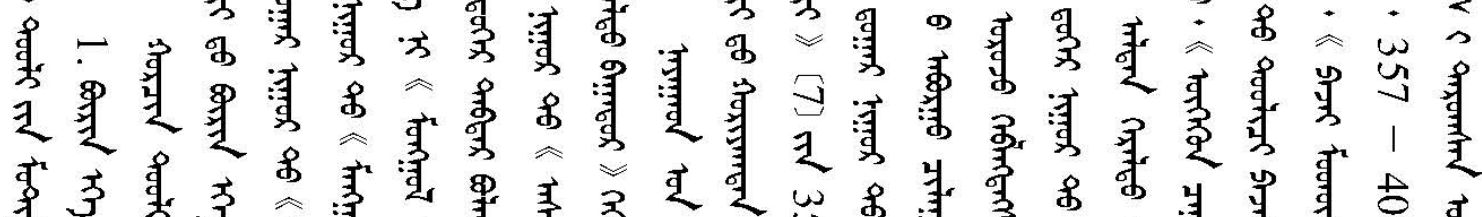

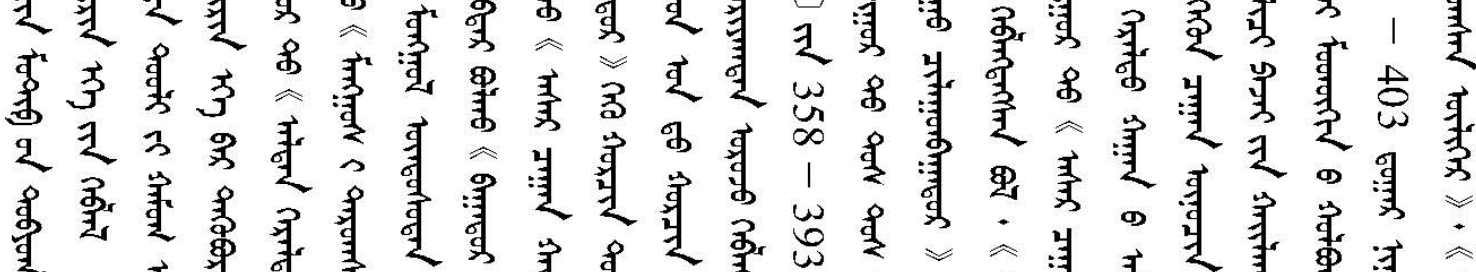

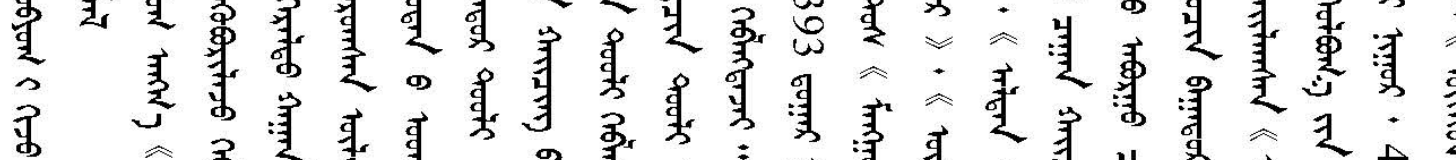

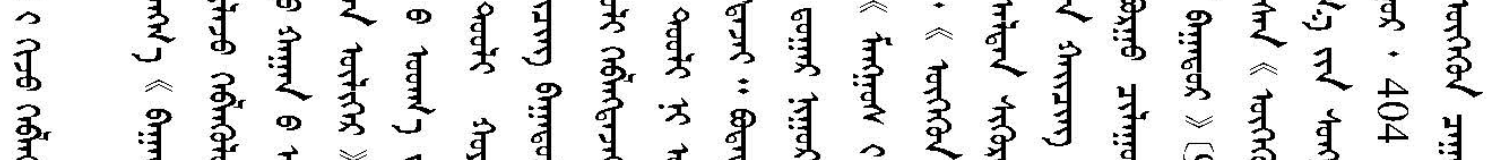

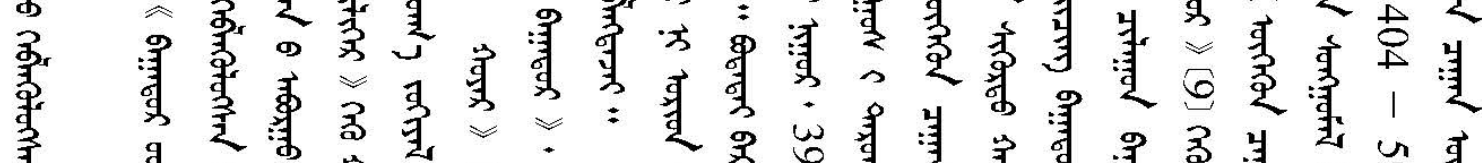

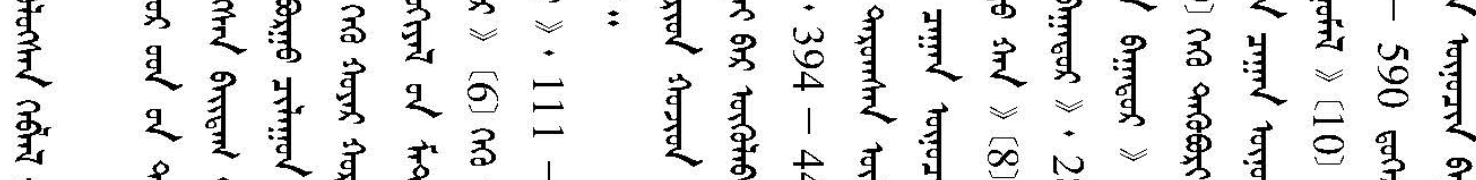
等

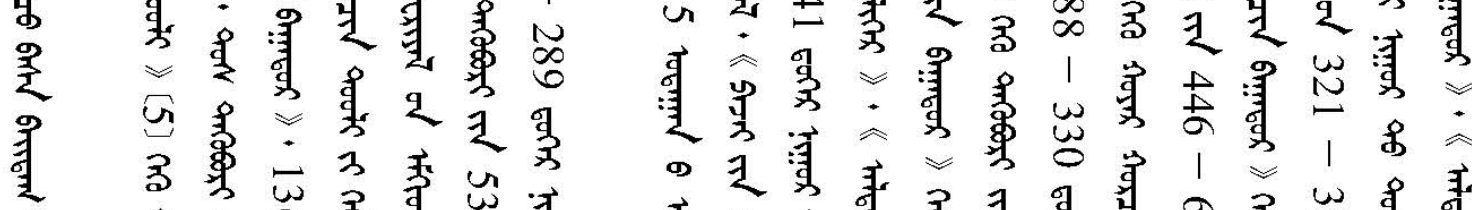

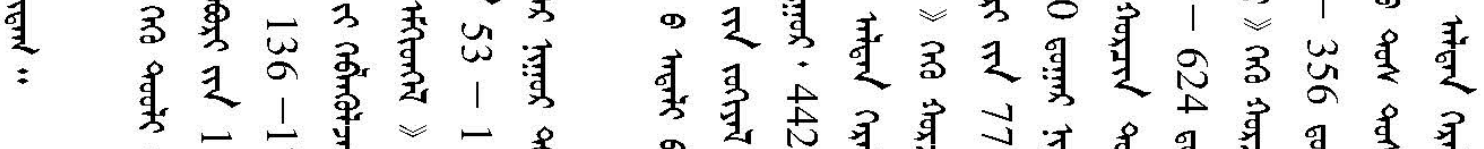

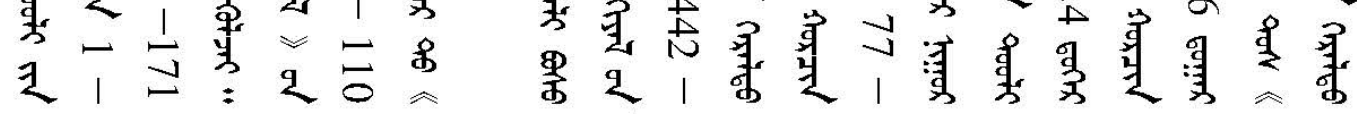




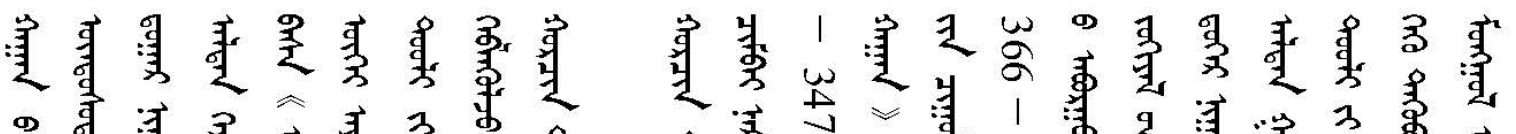

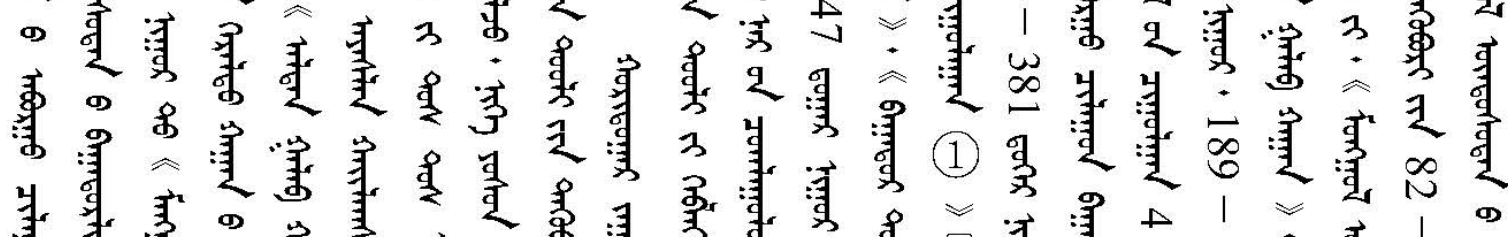

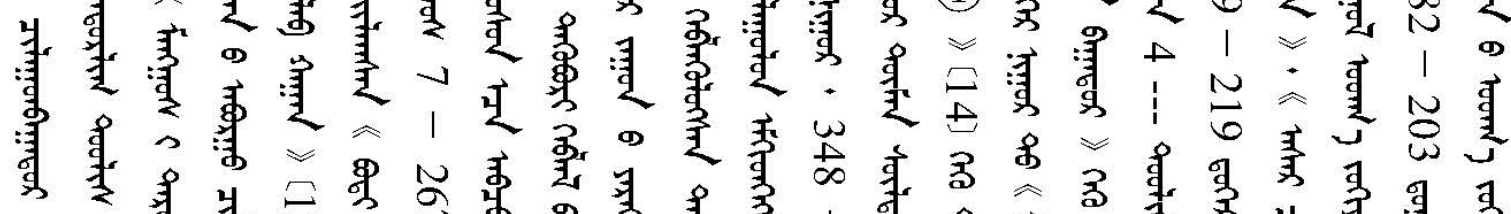

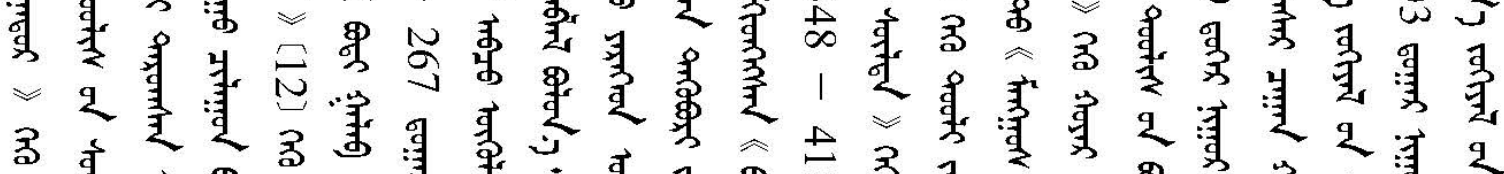

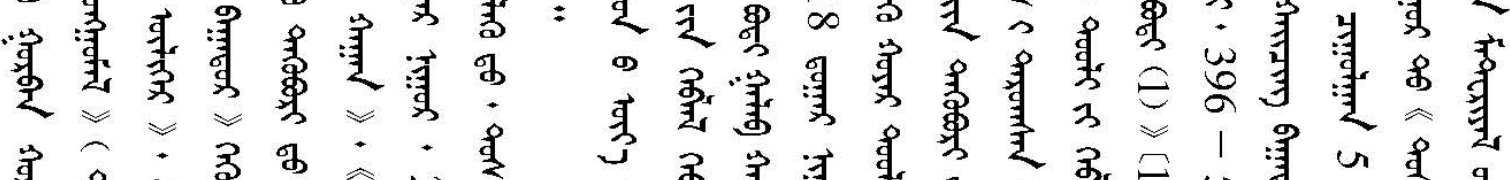

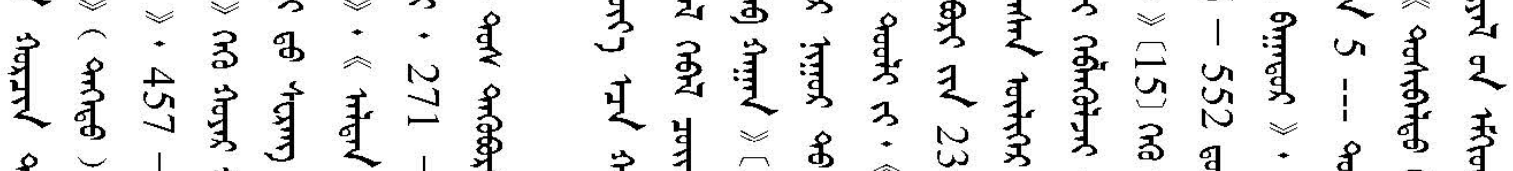

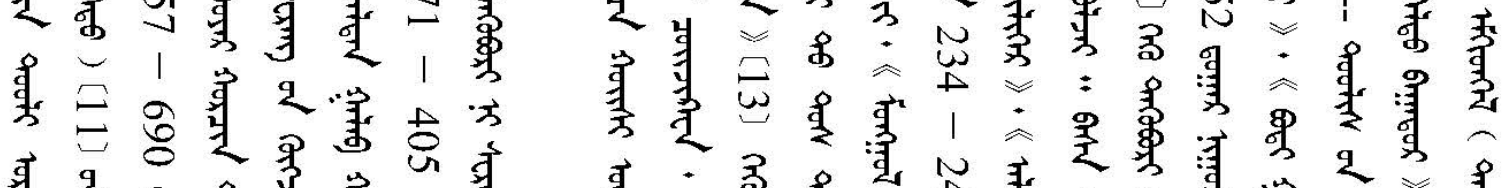

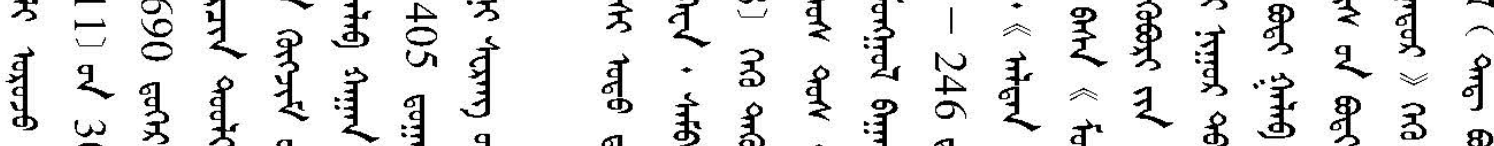

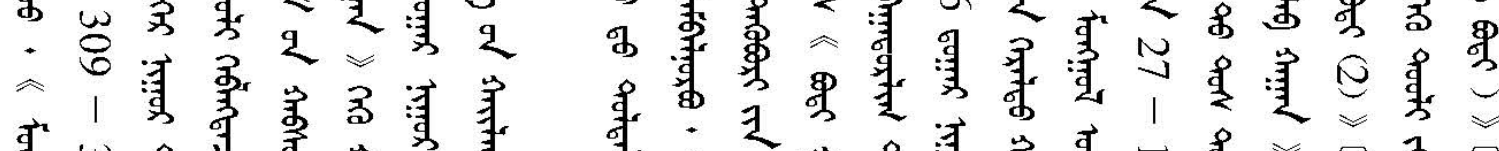

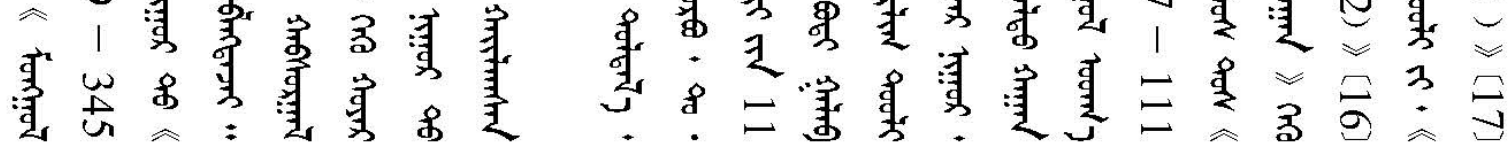

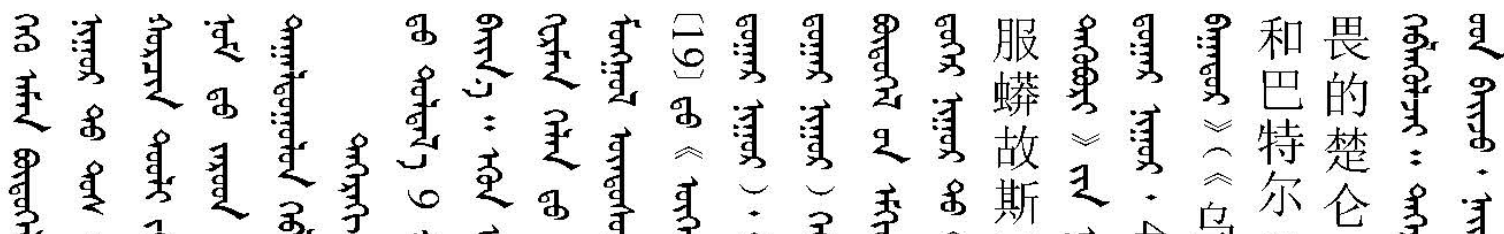

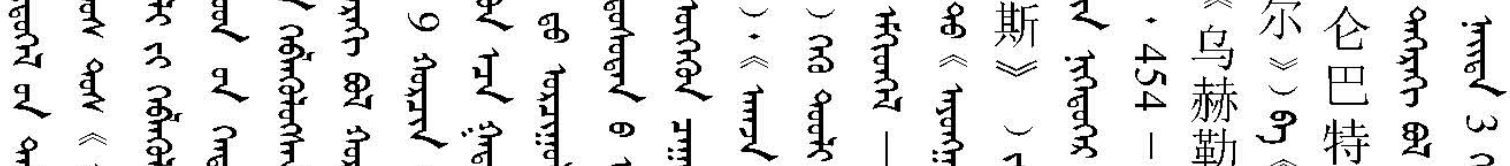

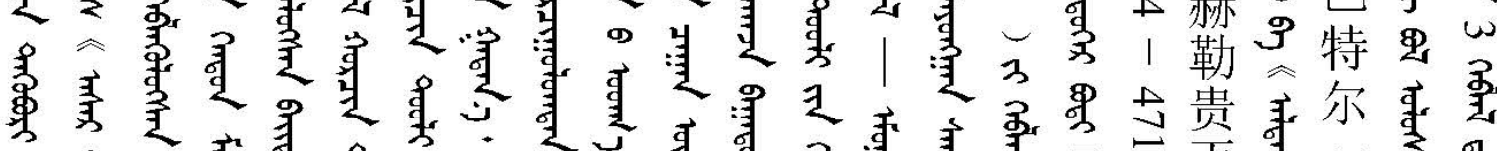

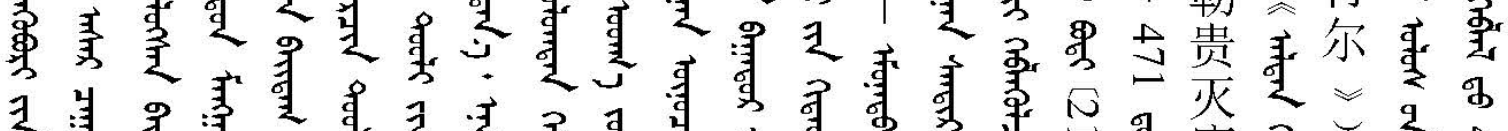

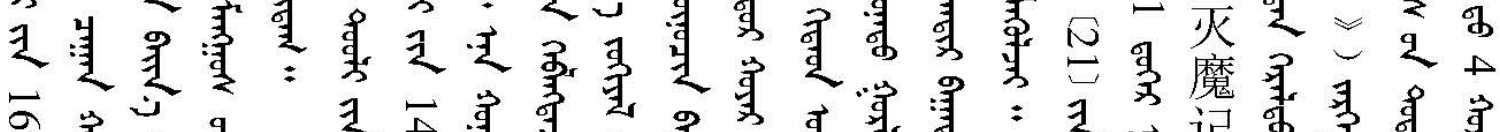

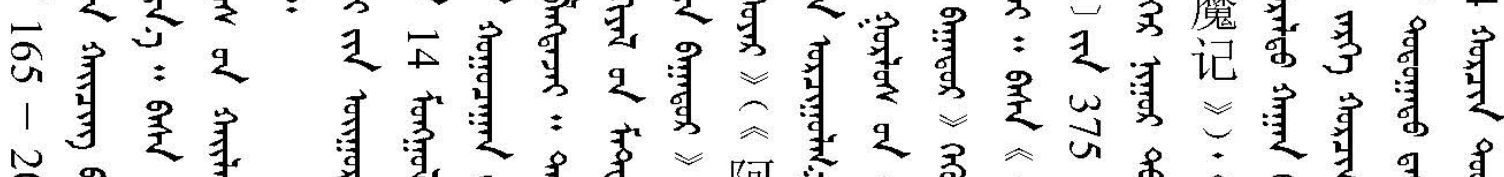

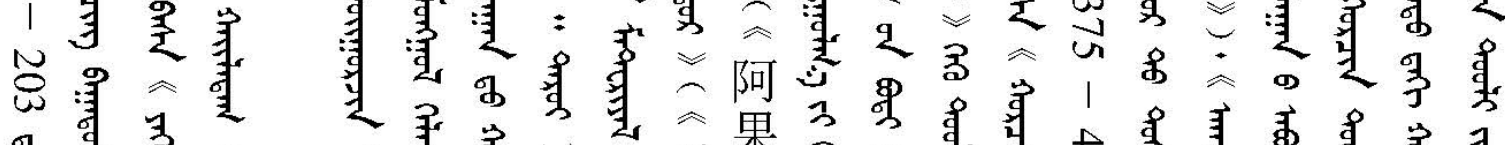

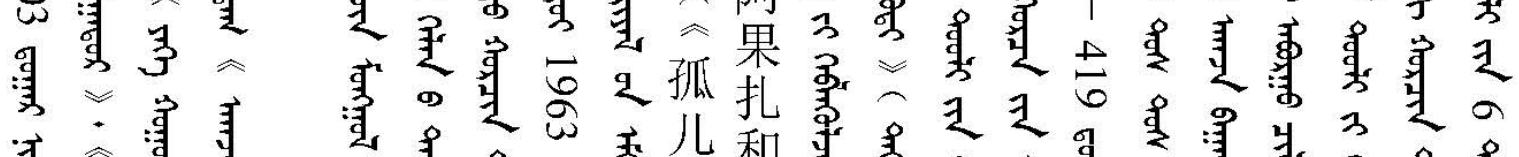

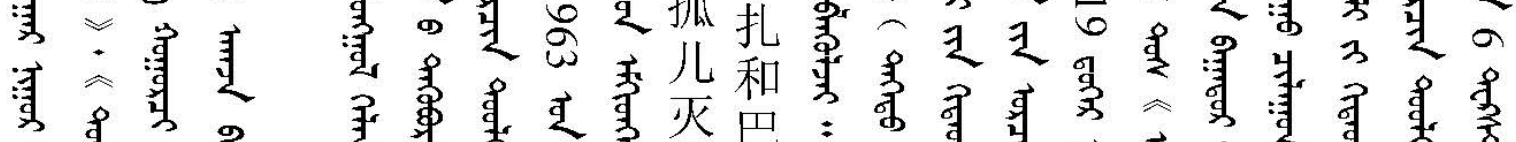

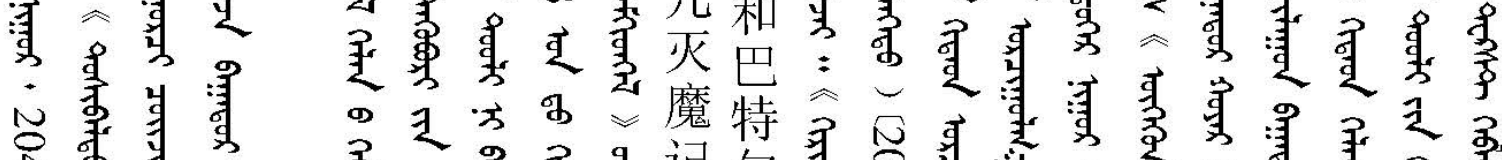

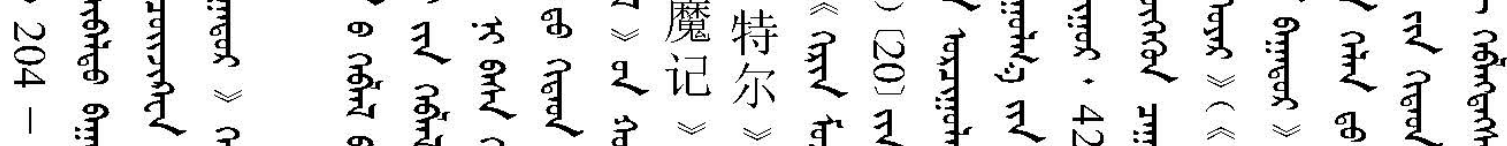

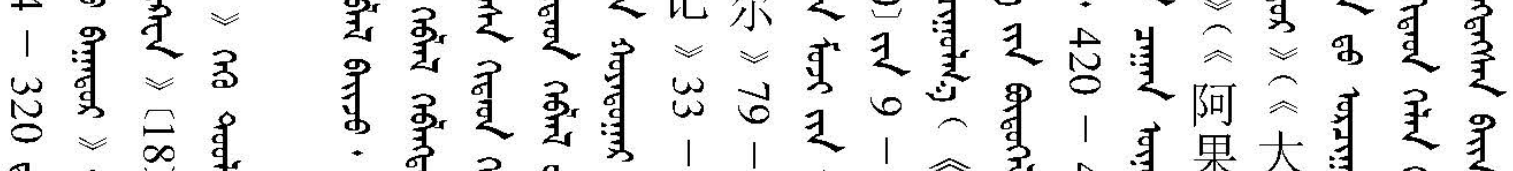

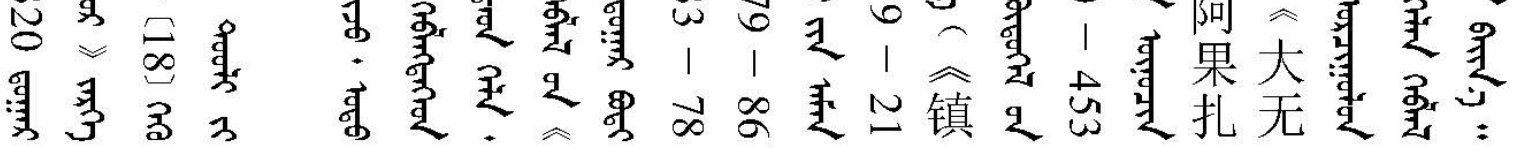




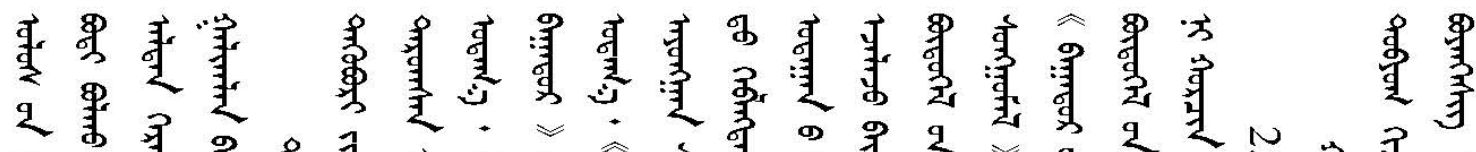

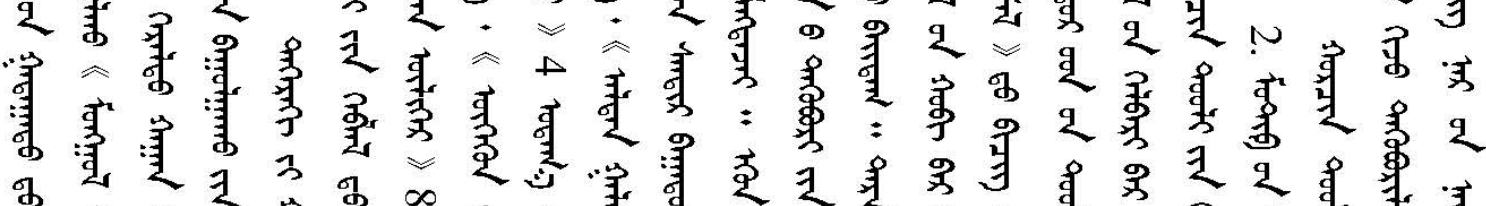

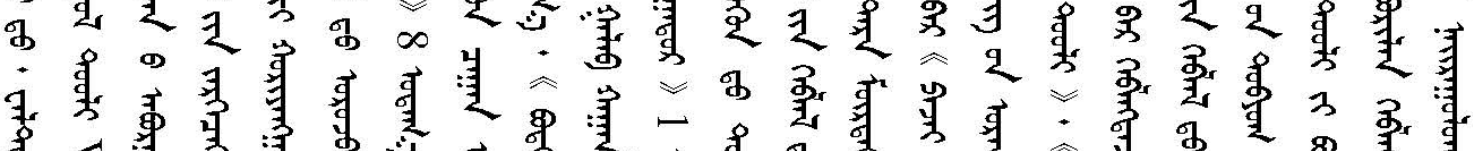

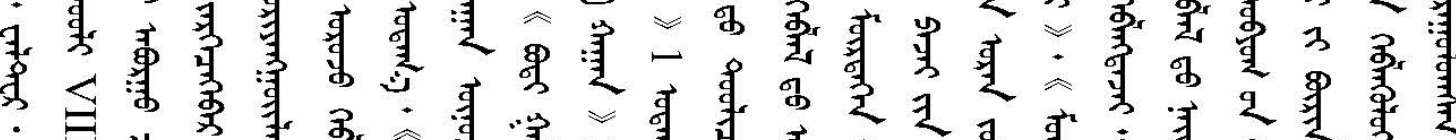

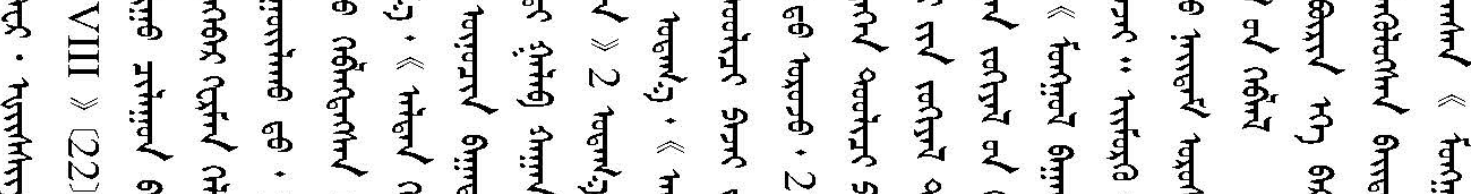

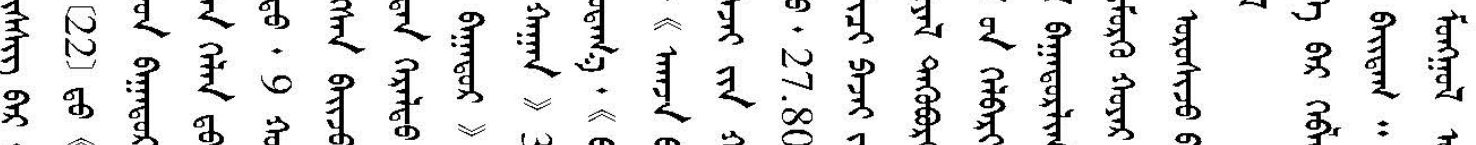

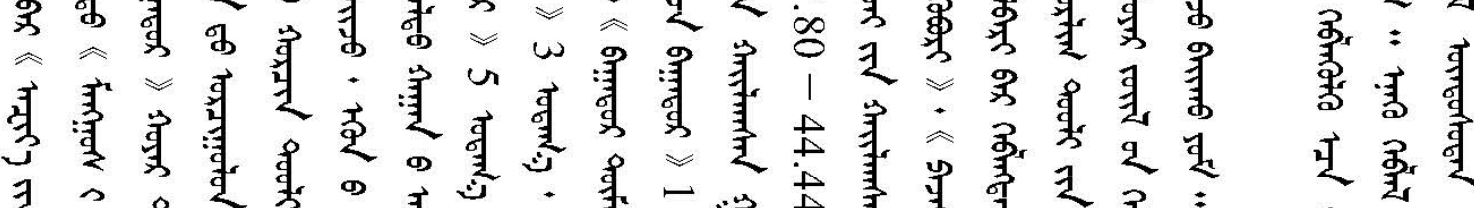

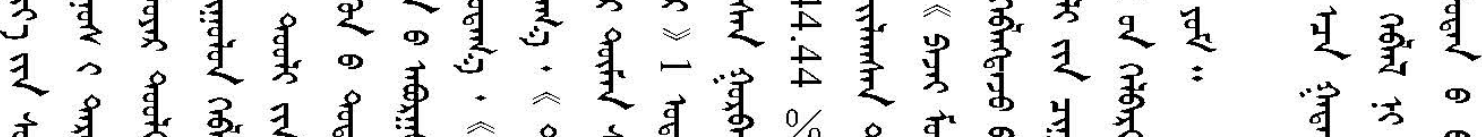

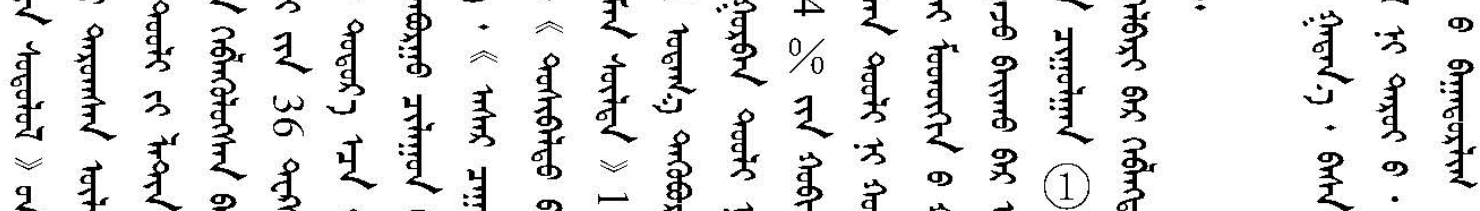

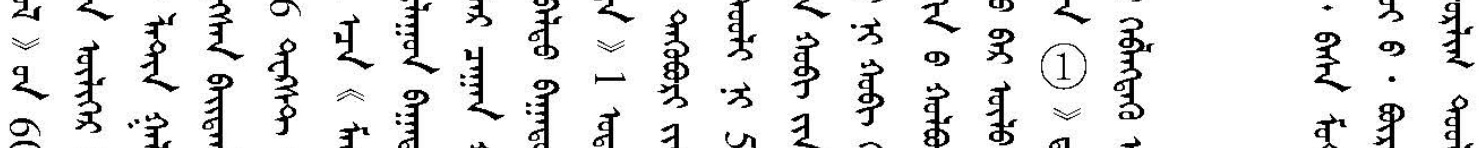

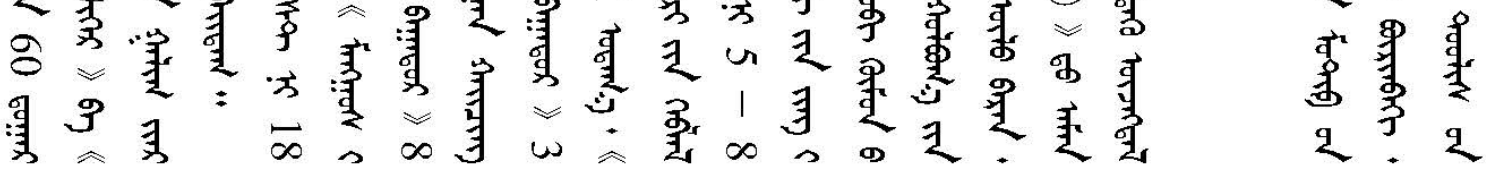

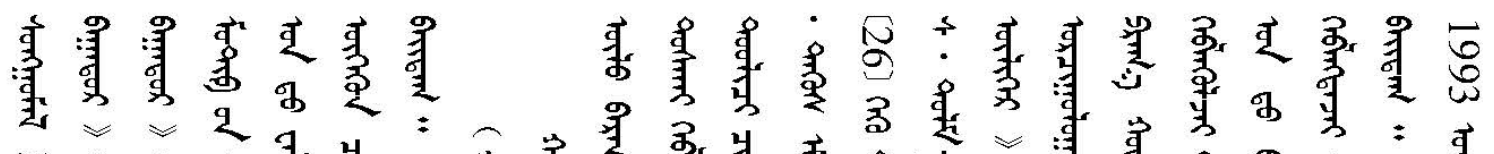

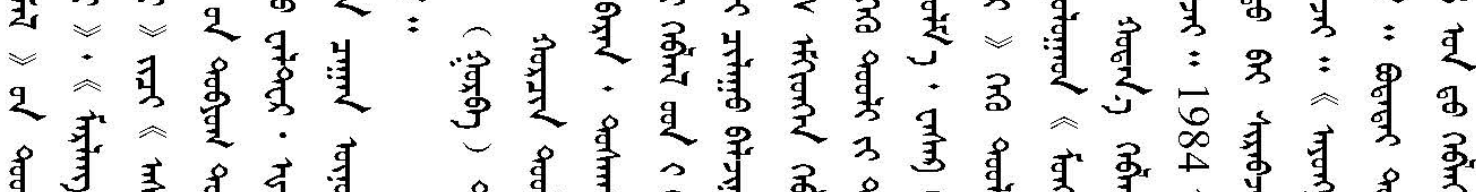

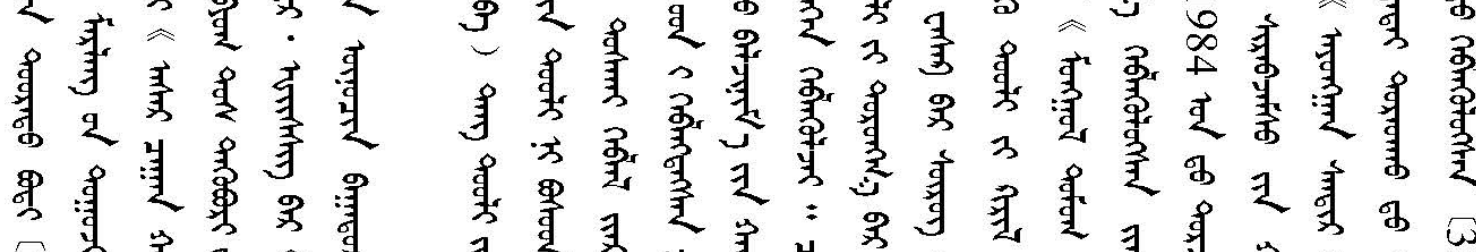

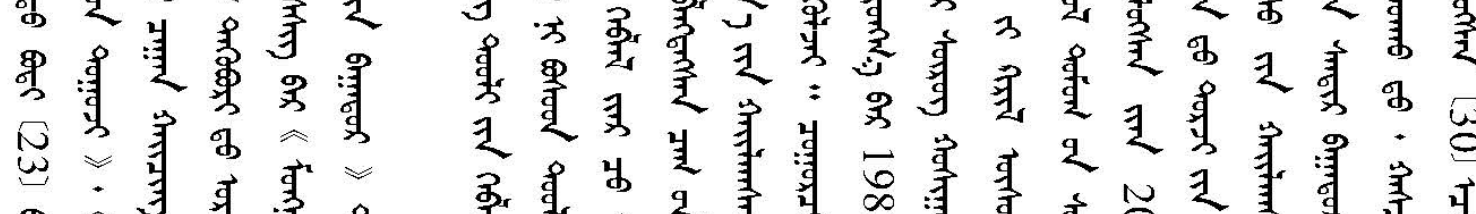

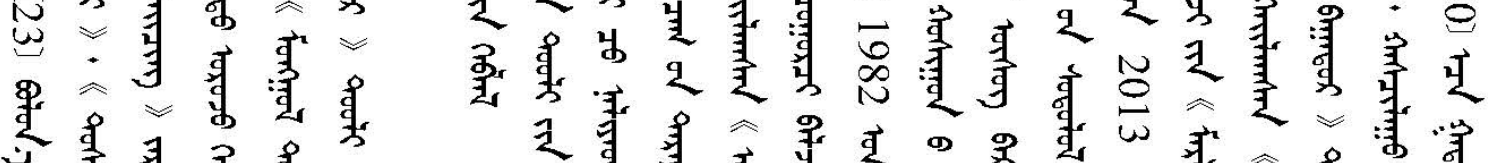

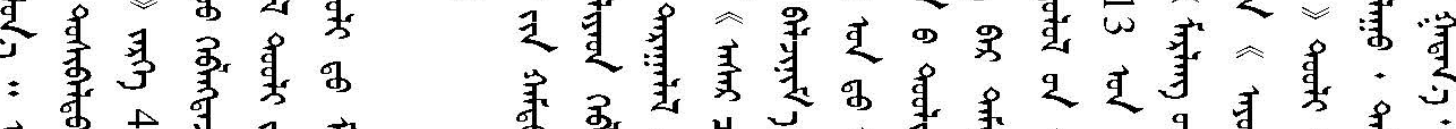

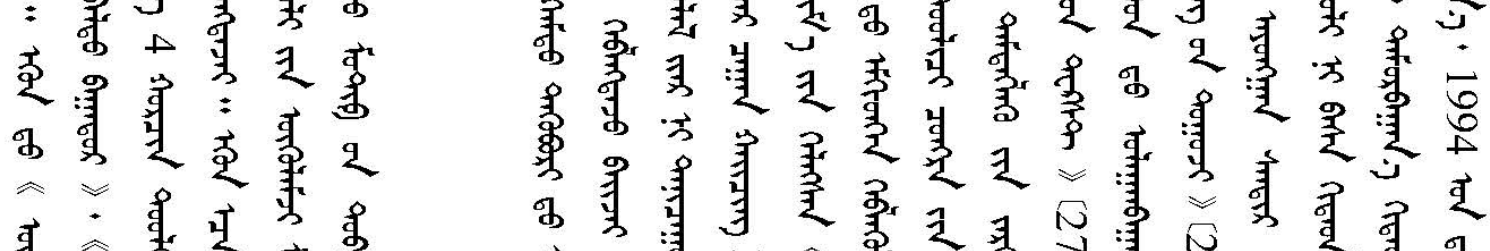

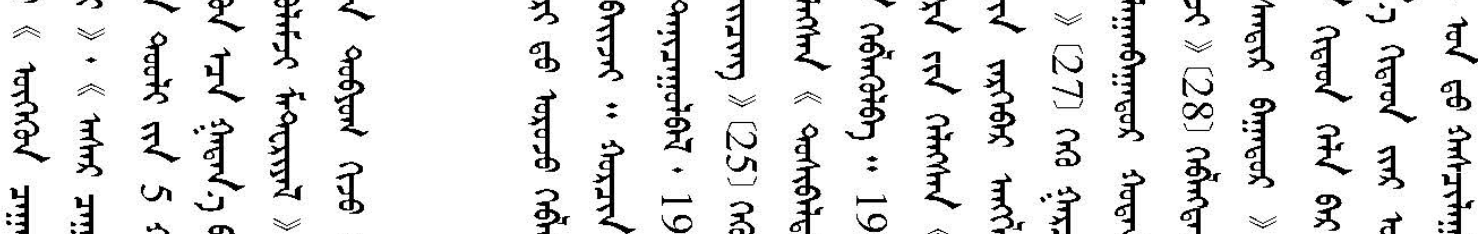

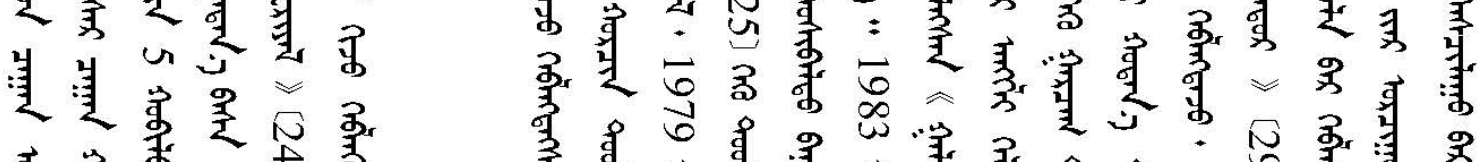

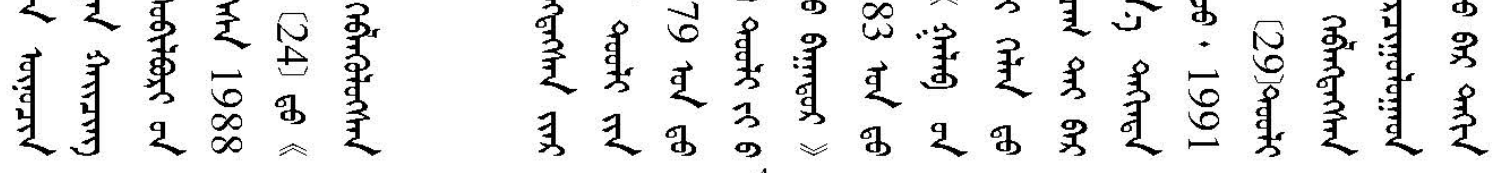




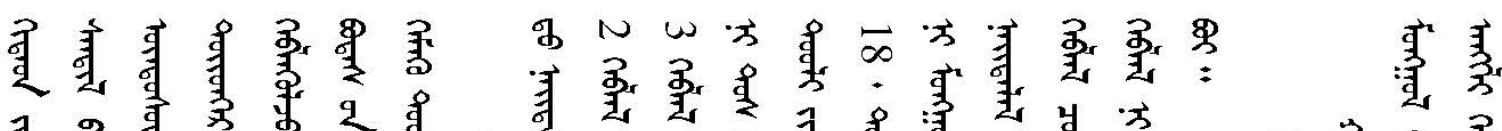

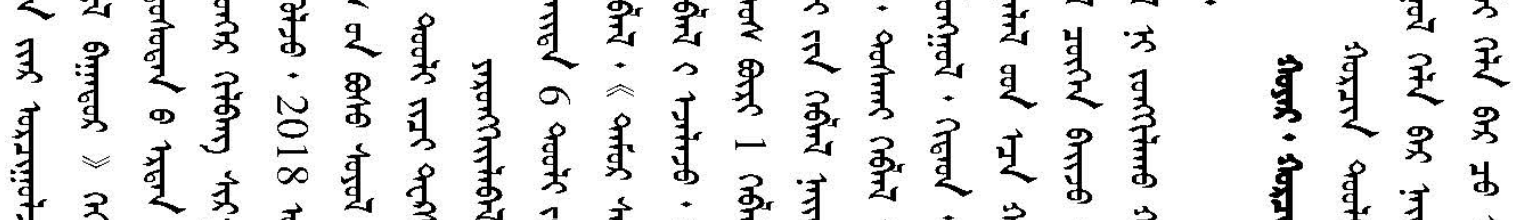

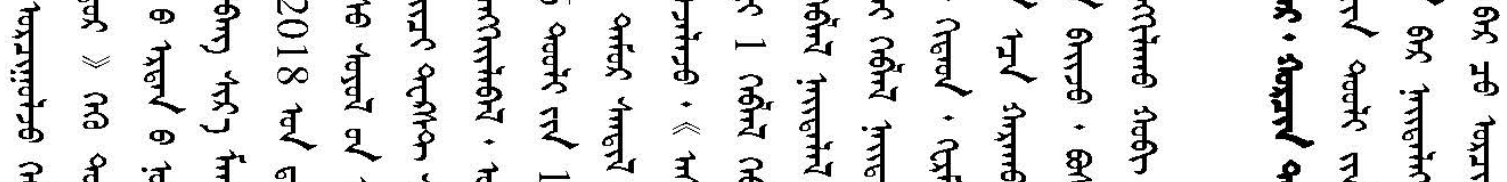

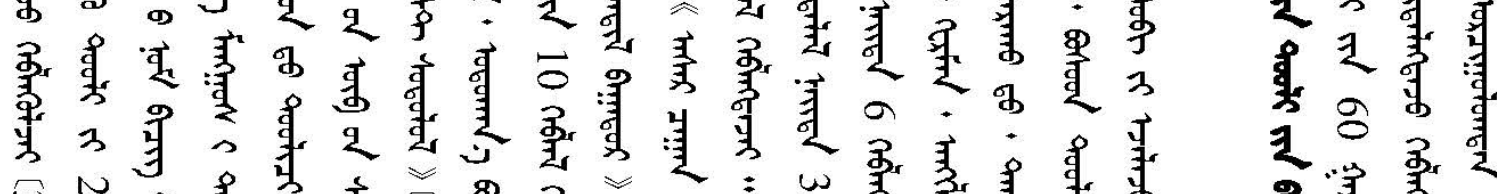

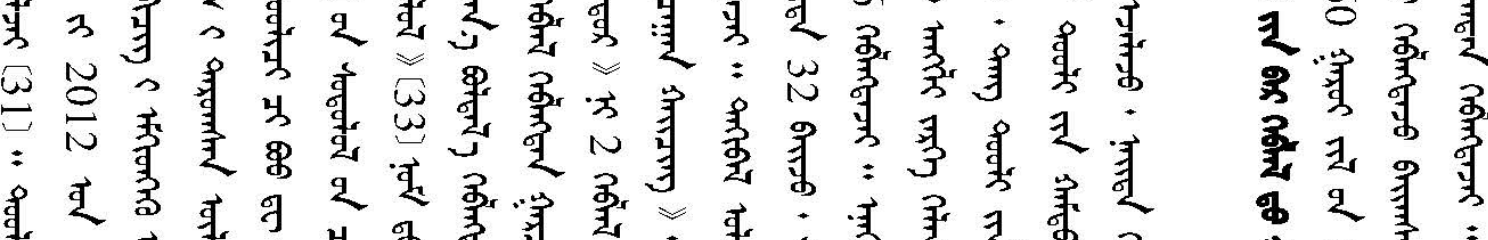

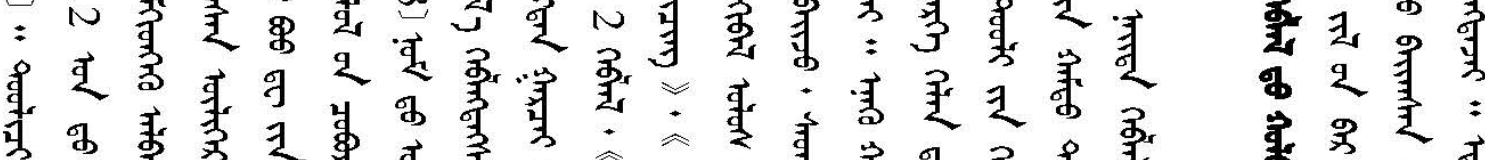

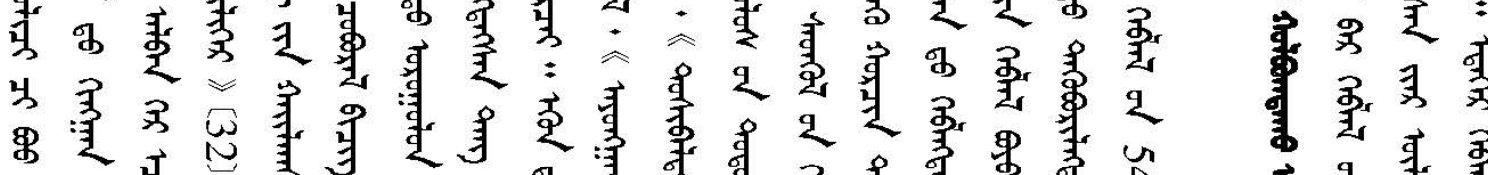

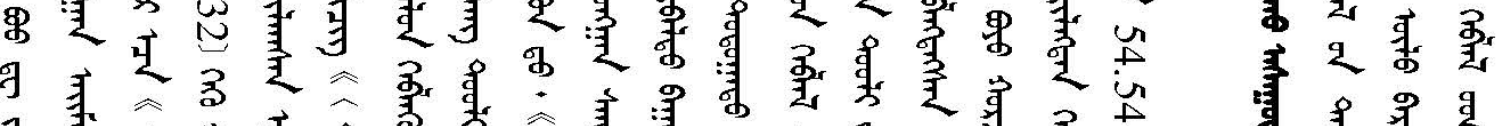

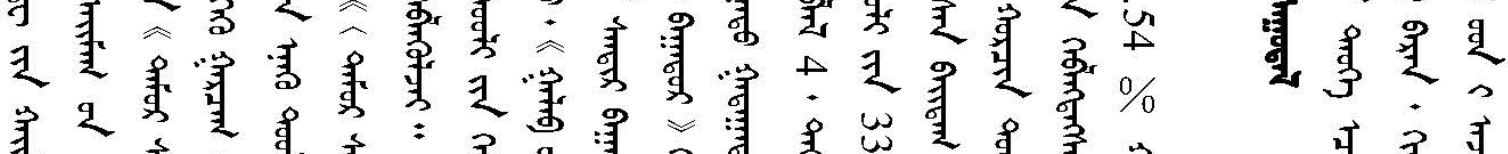

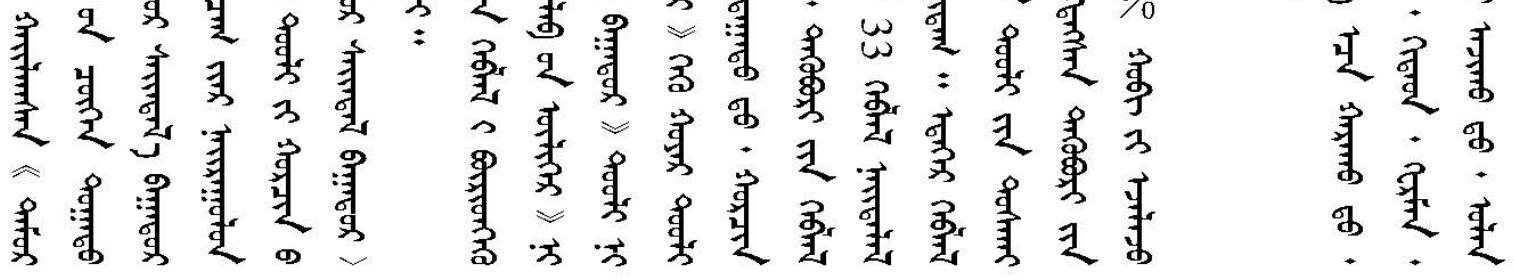

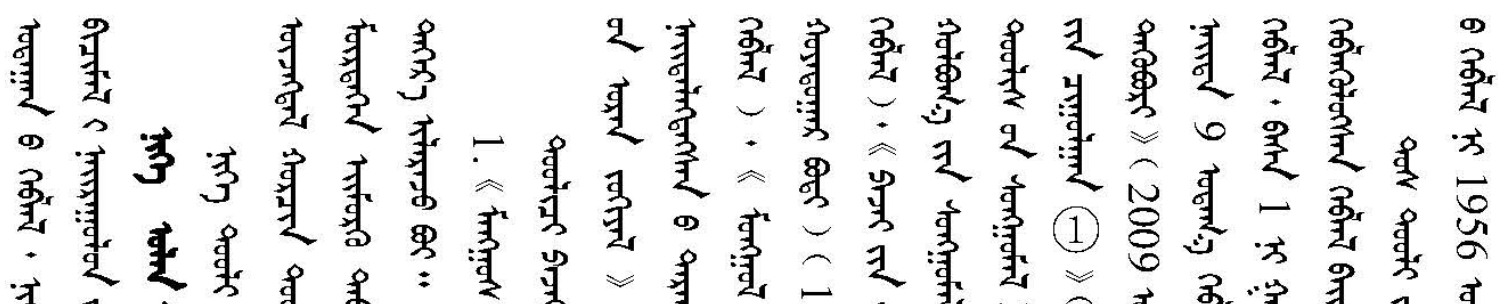

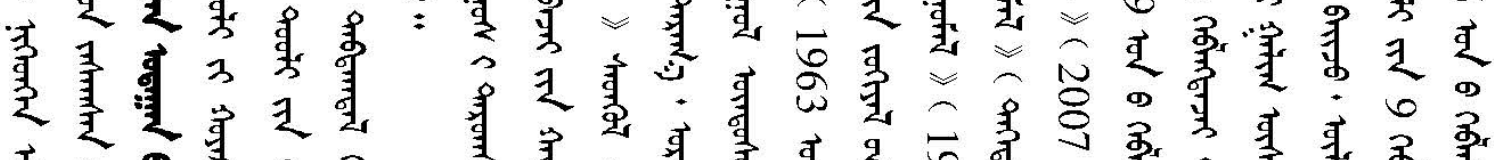

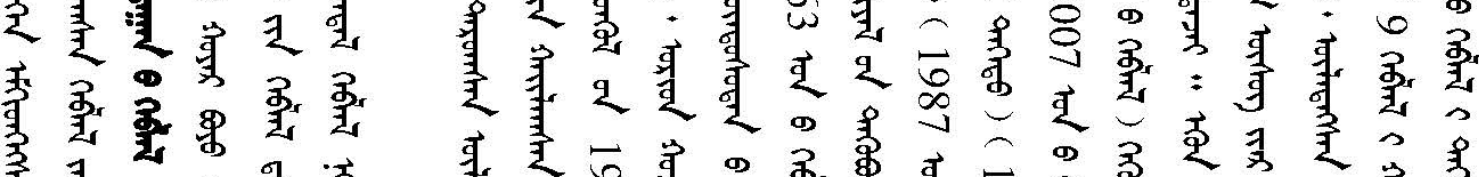

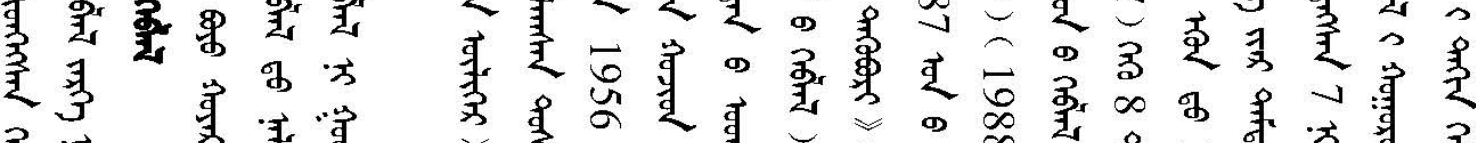

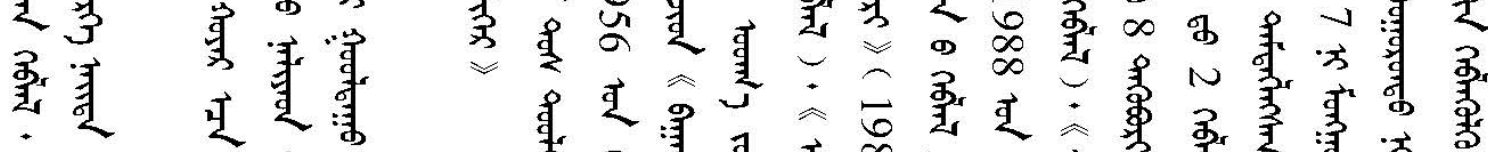

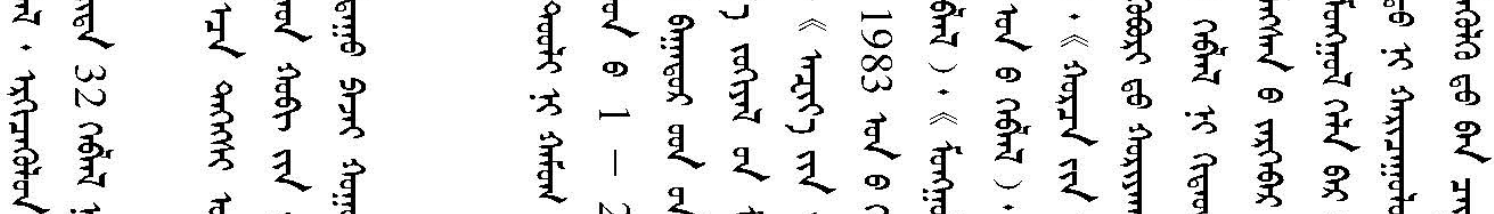

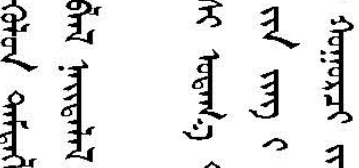

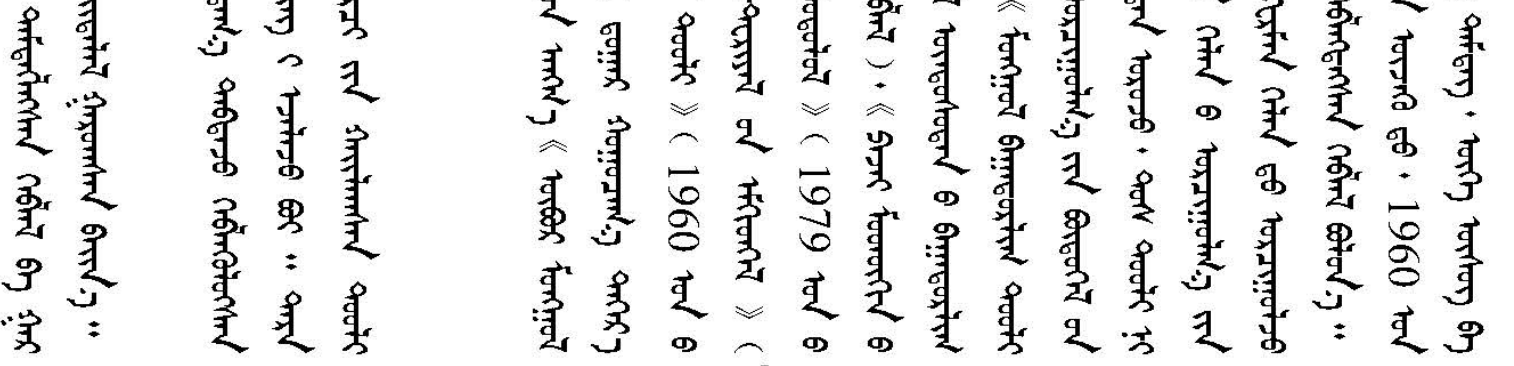




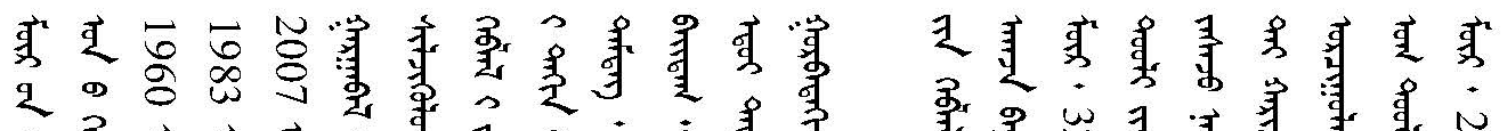

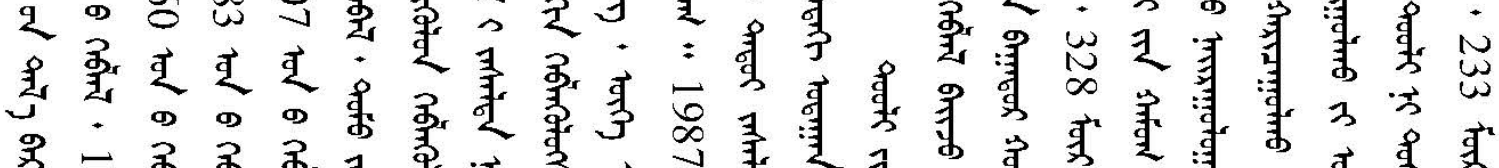

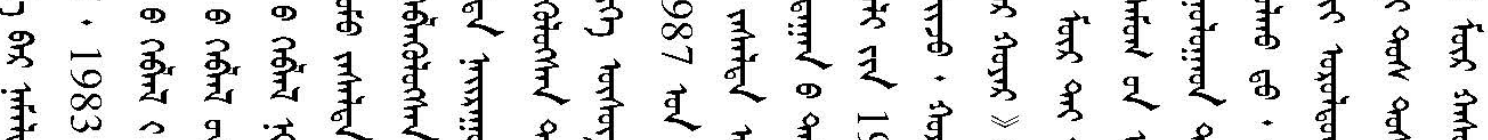

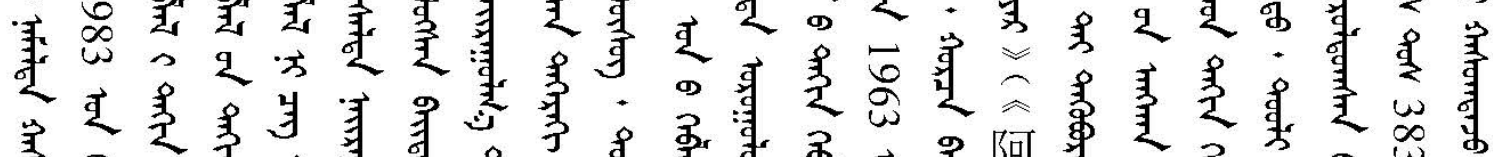

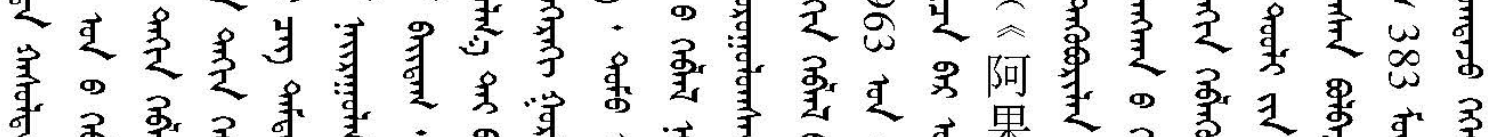

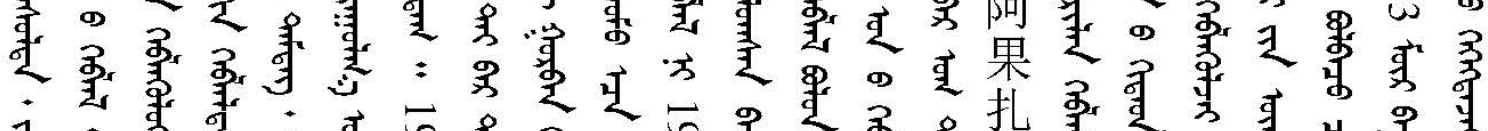

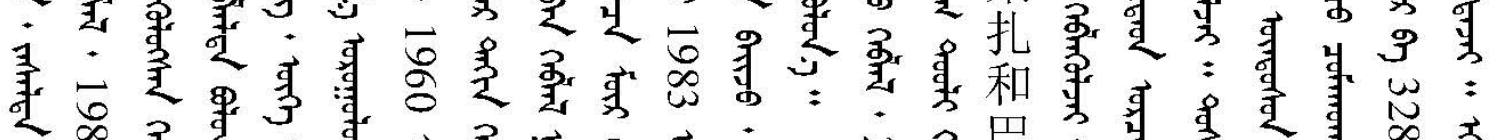

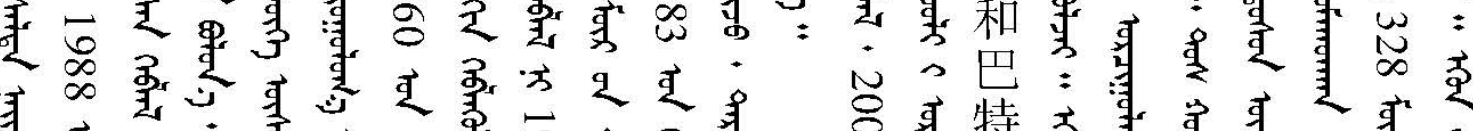

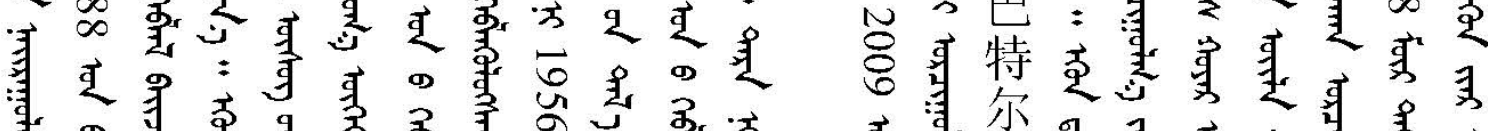

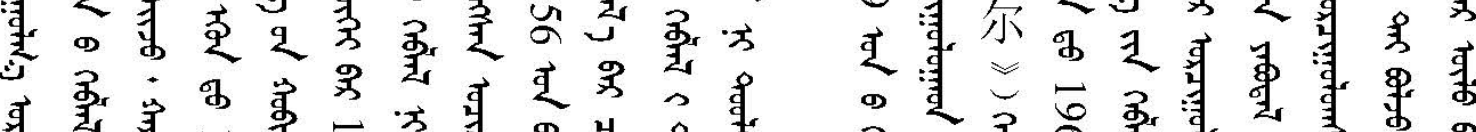

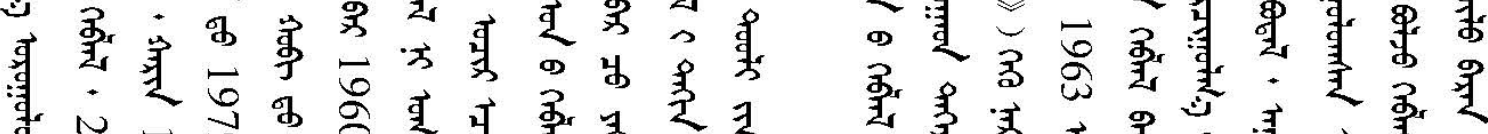

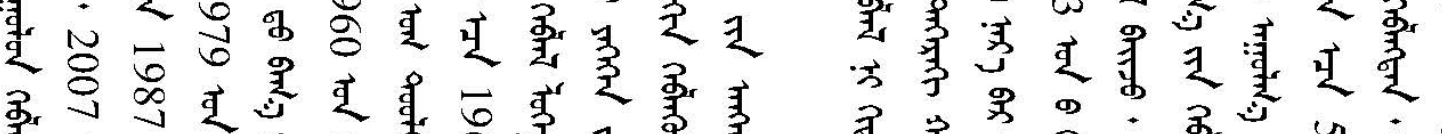

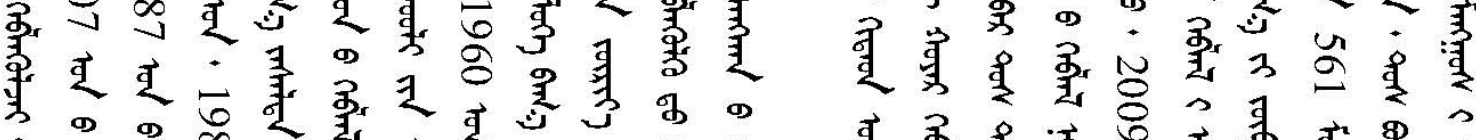

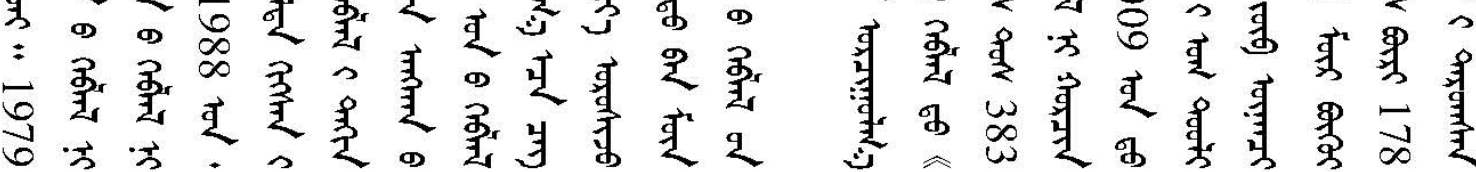

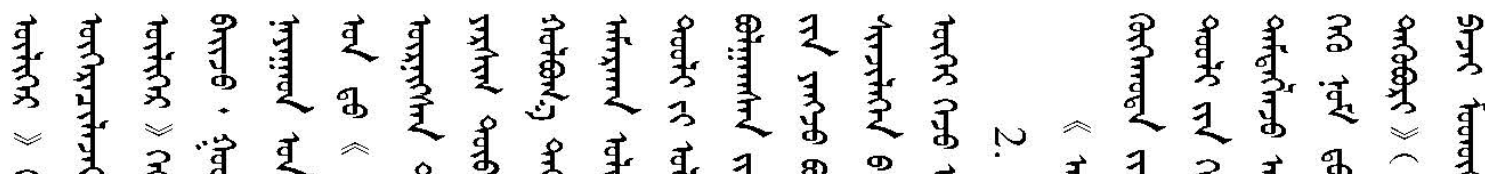

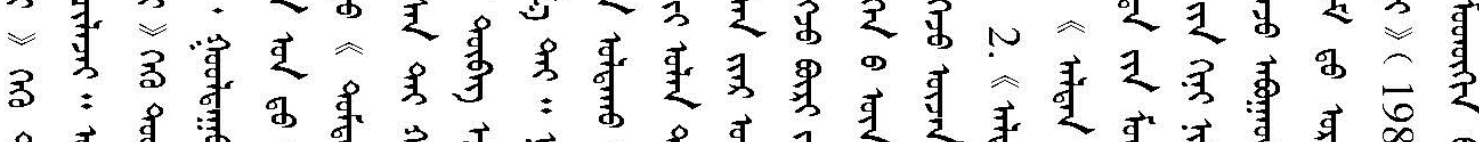

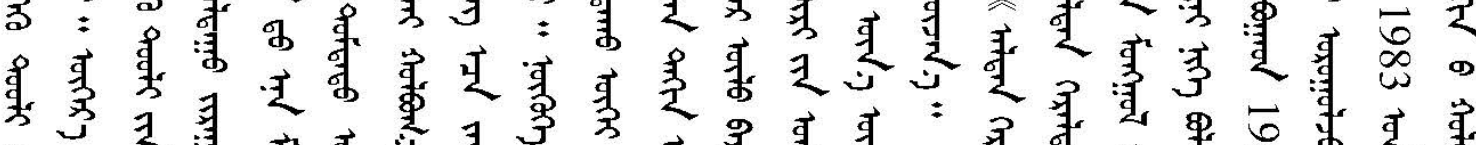

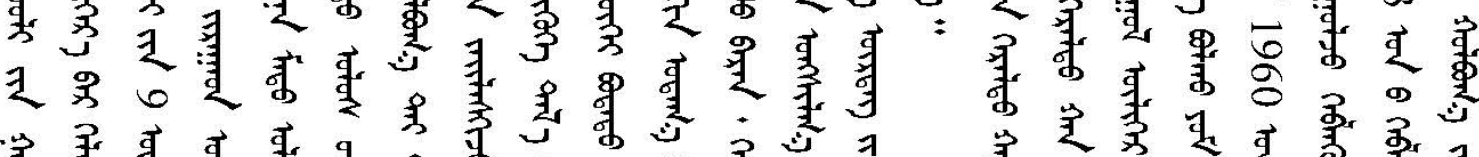

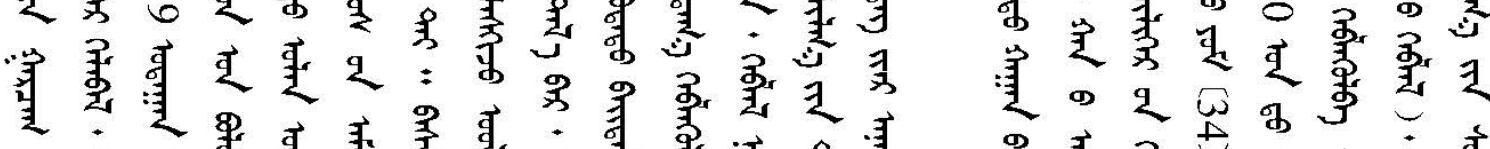

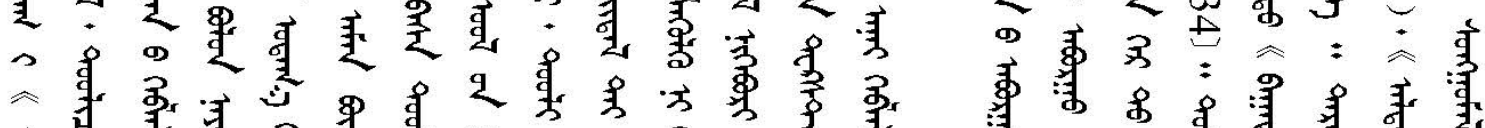

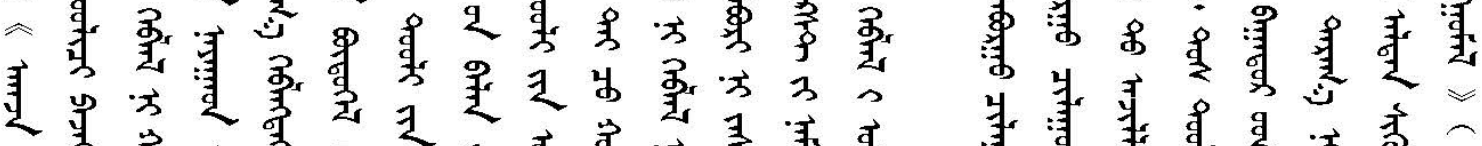

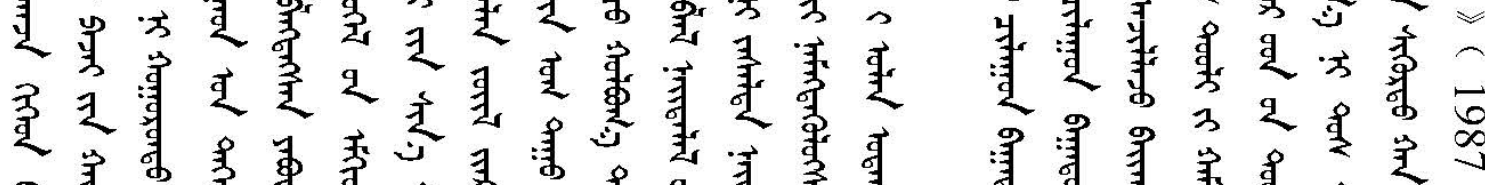

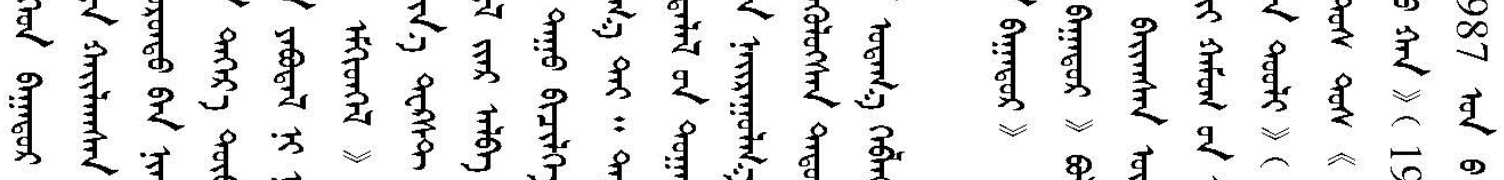

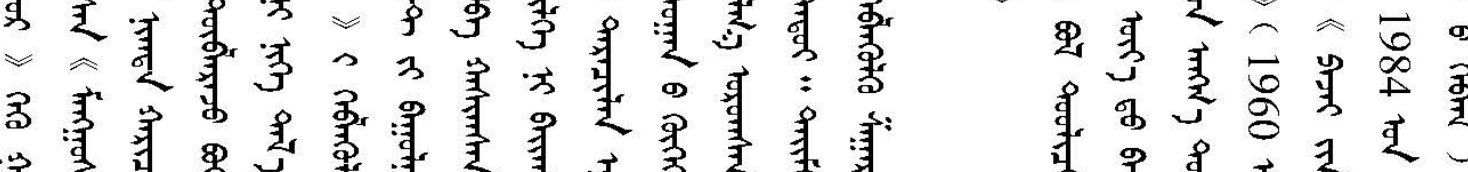

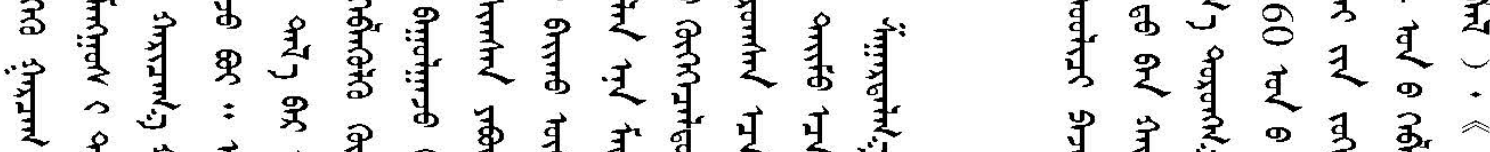

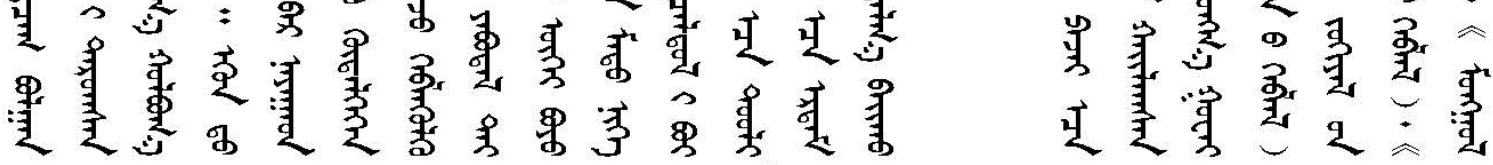




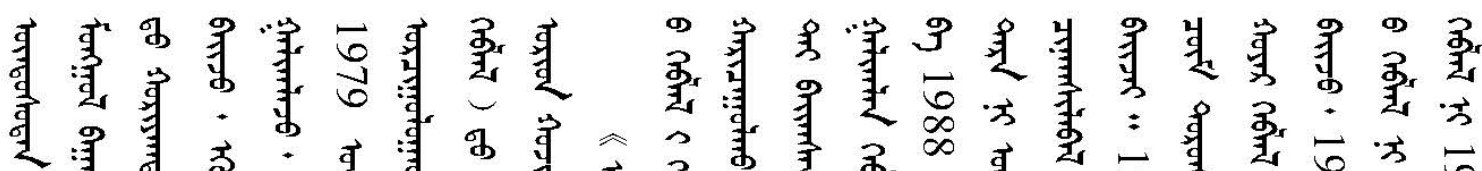

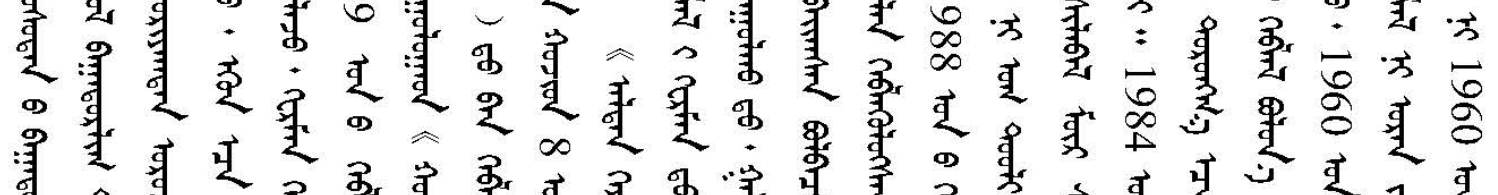

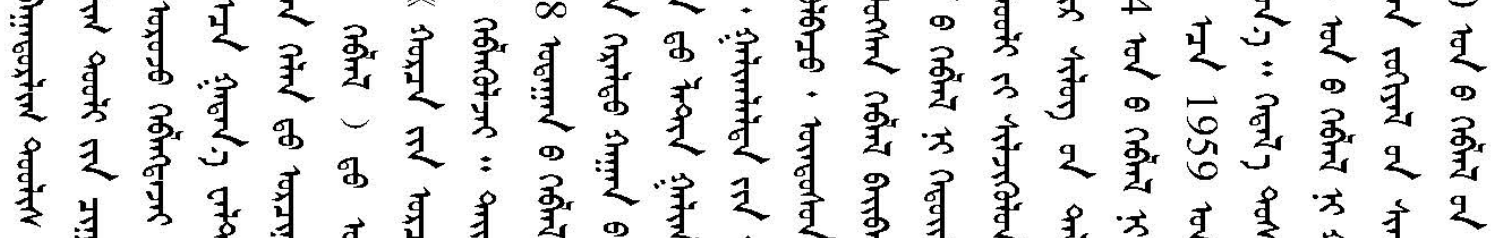

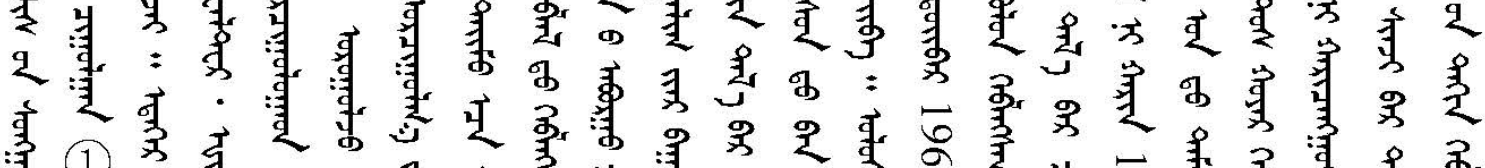

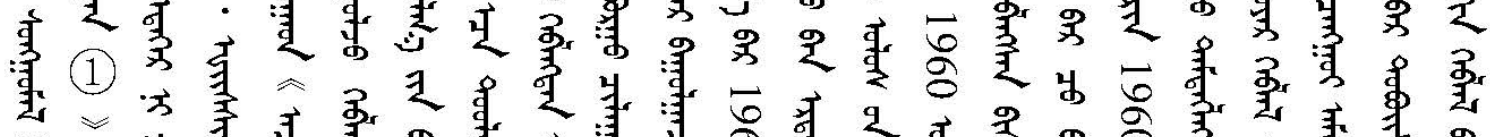

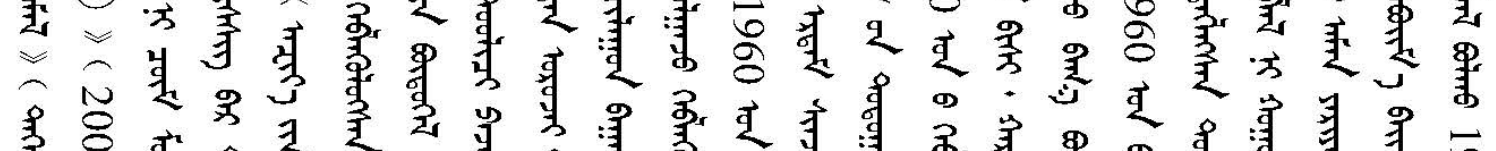

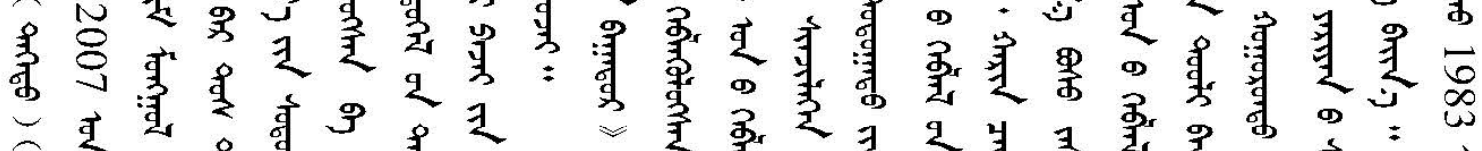

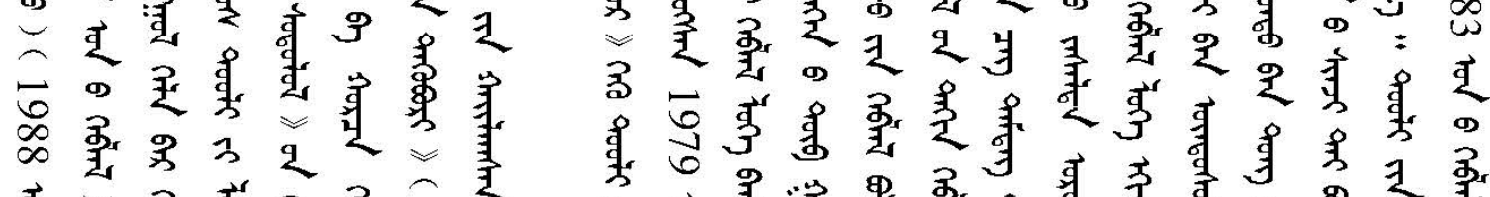

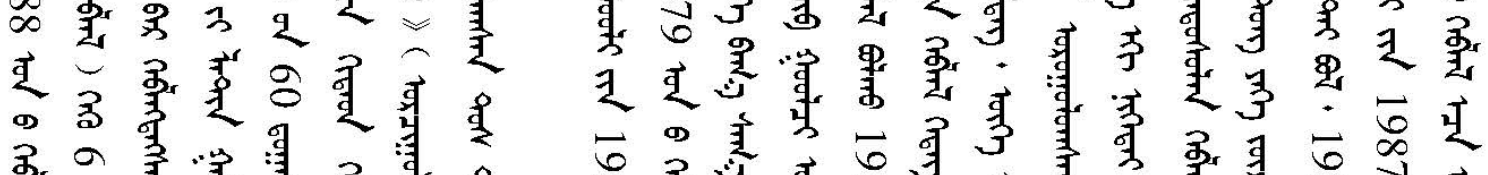

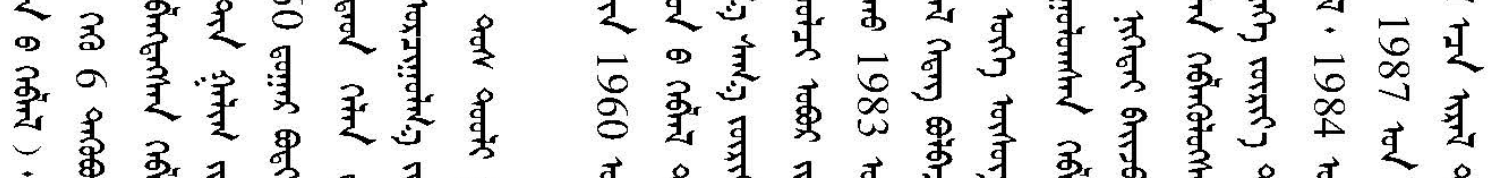

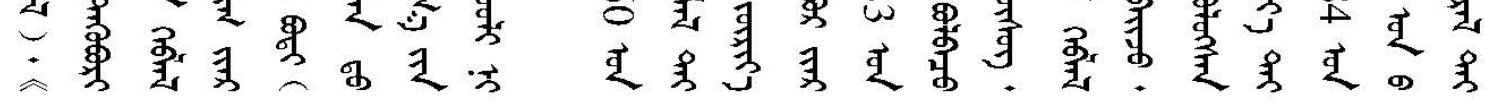

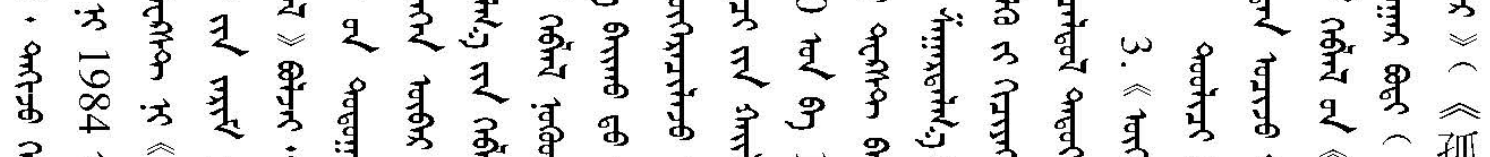

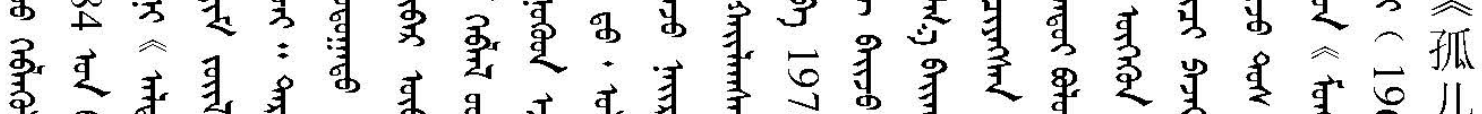

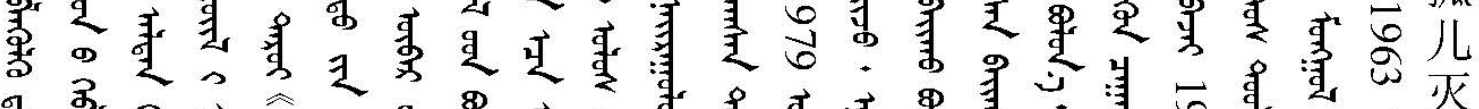

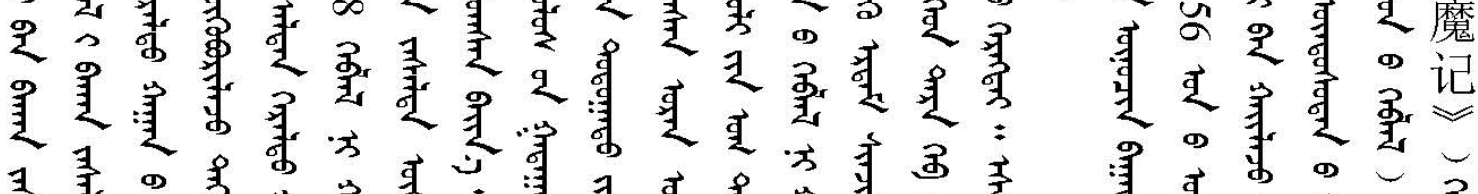

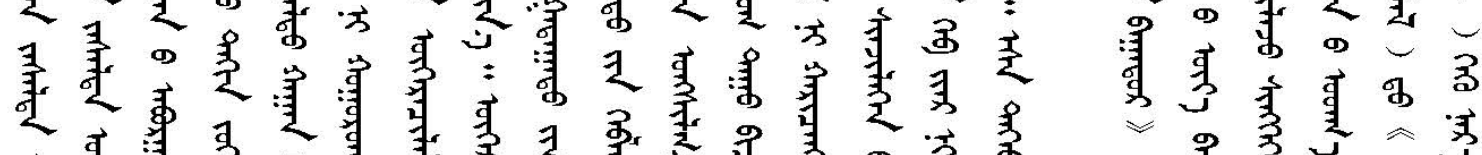

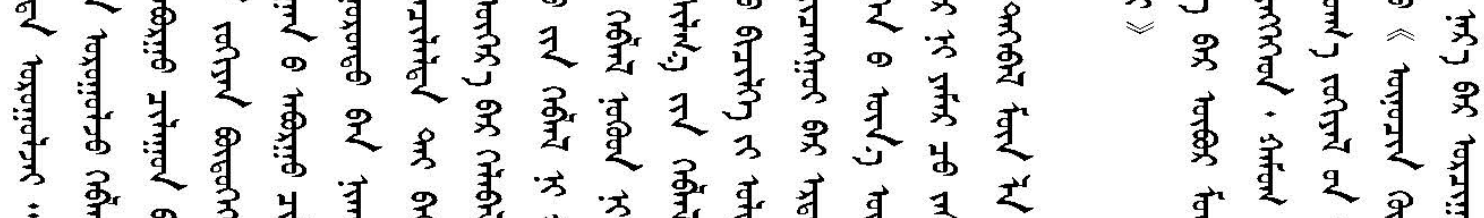

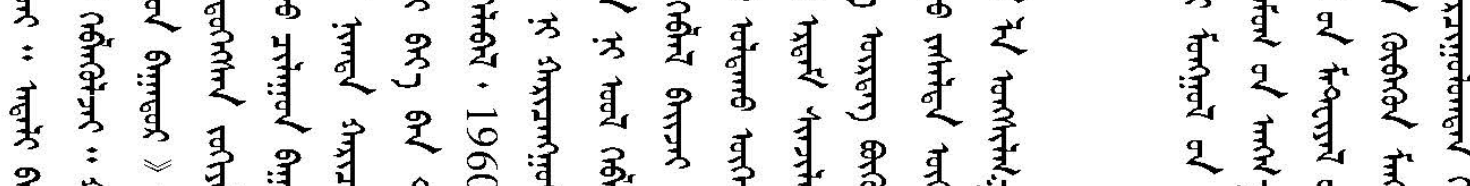

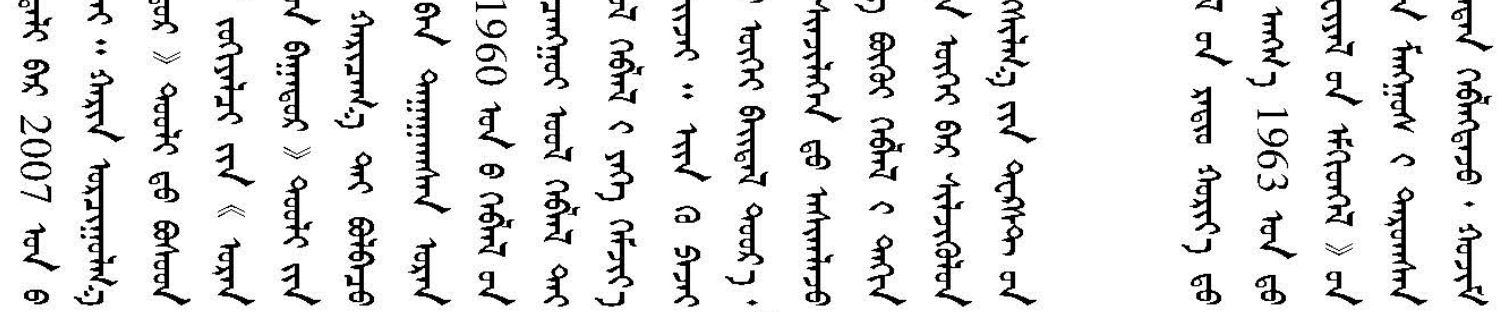




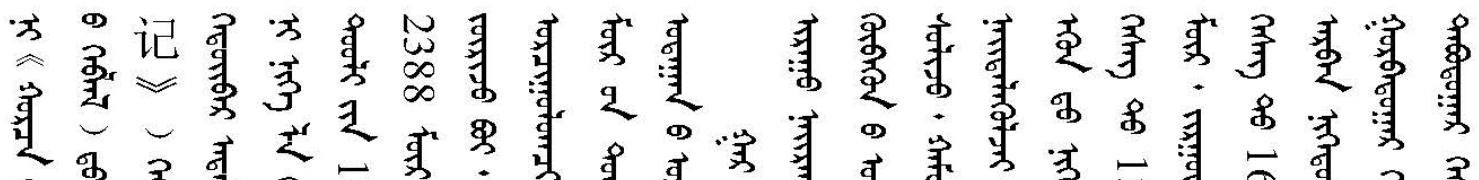

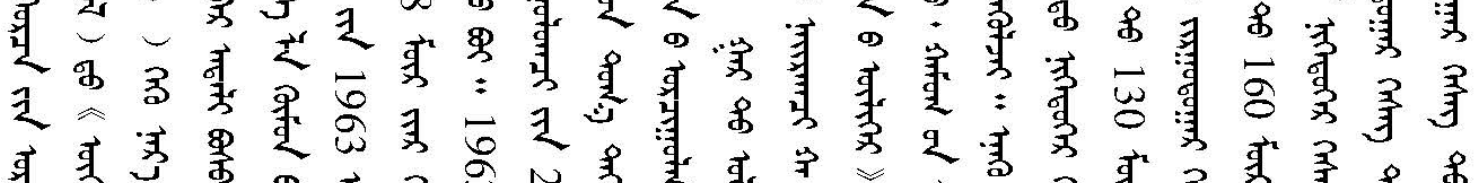

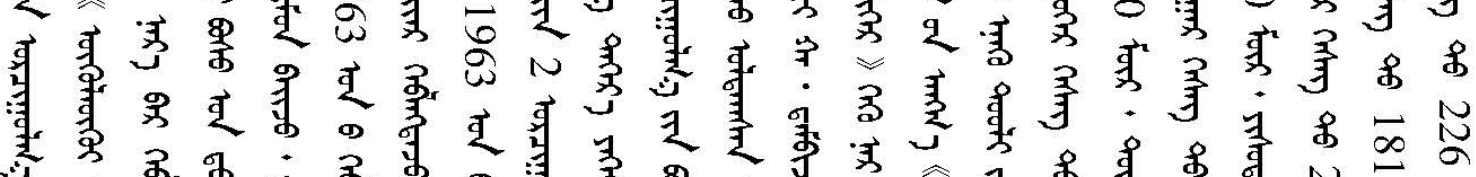

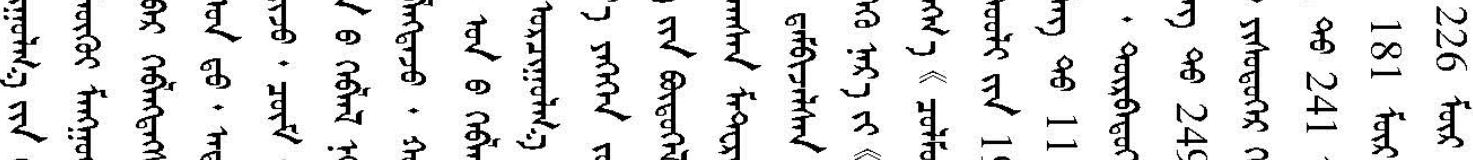

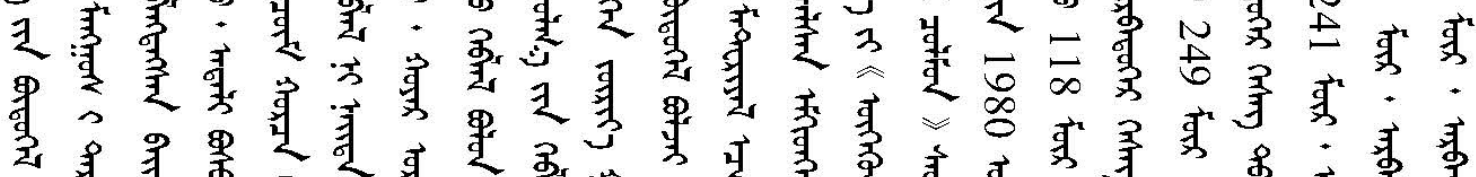

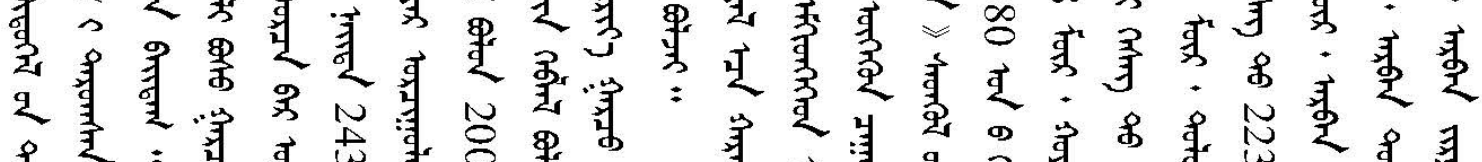

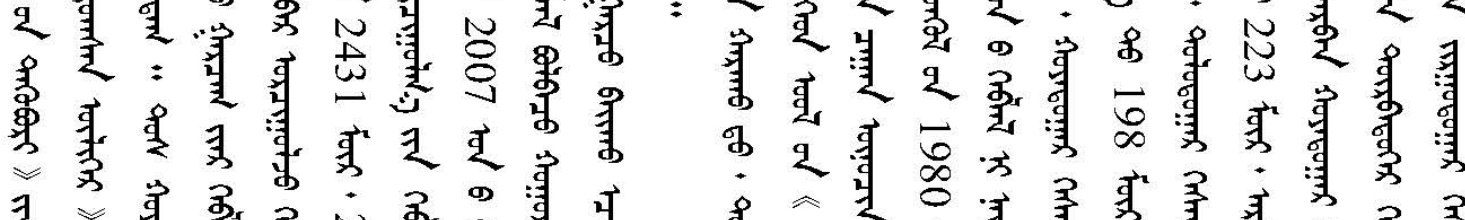

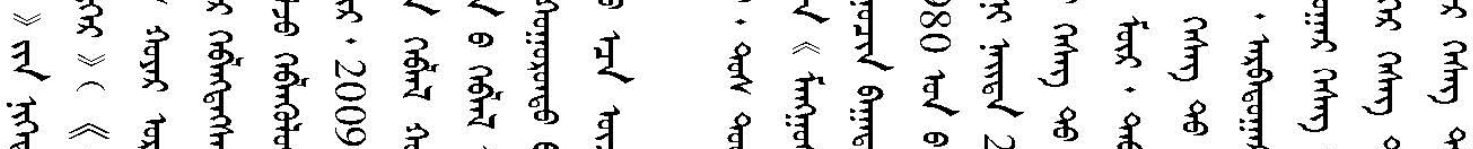

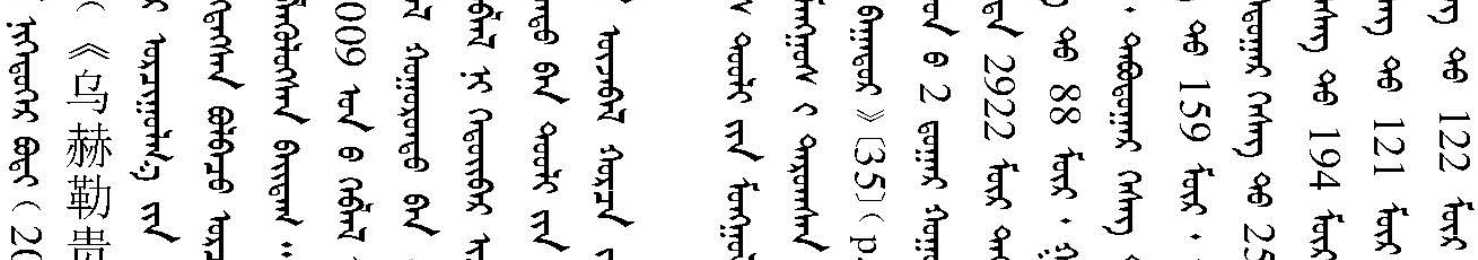

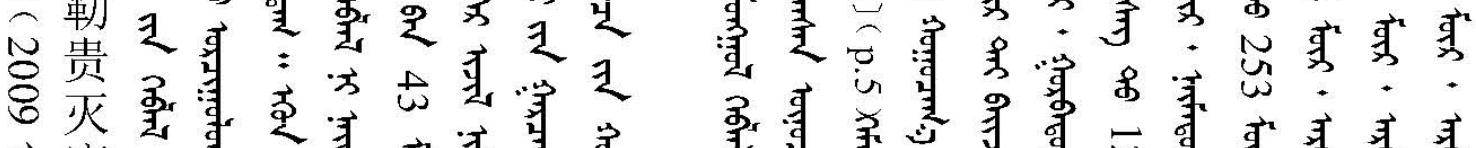

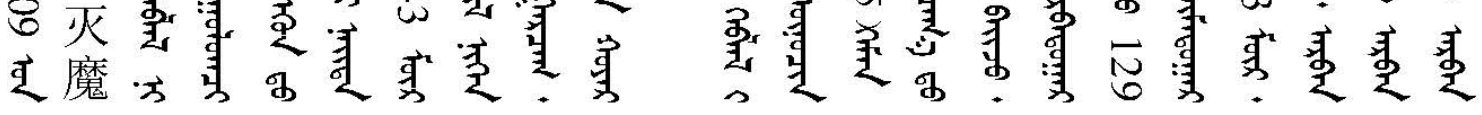

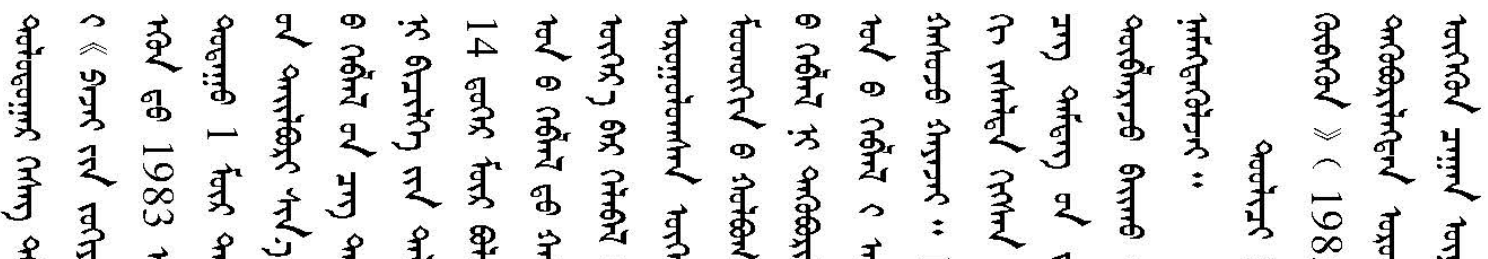

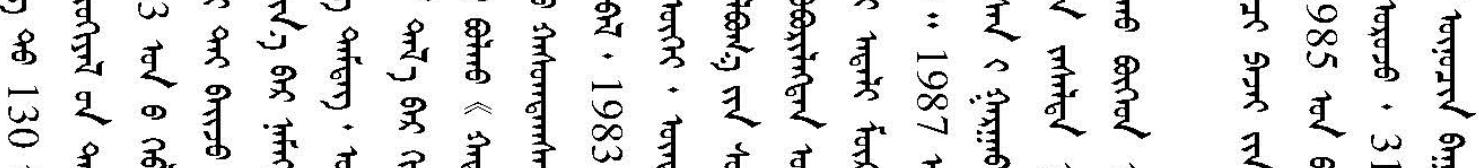

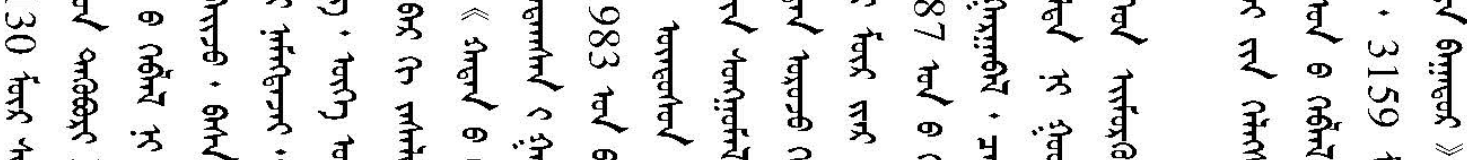

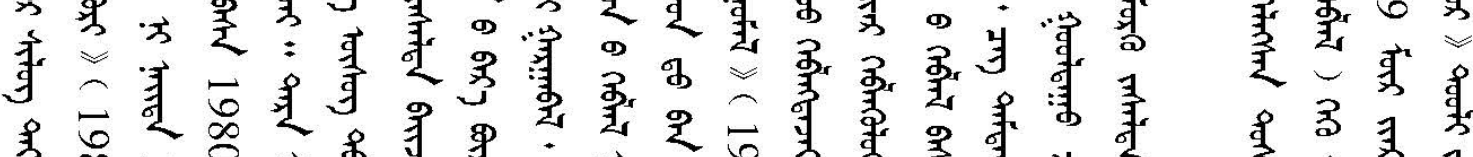

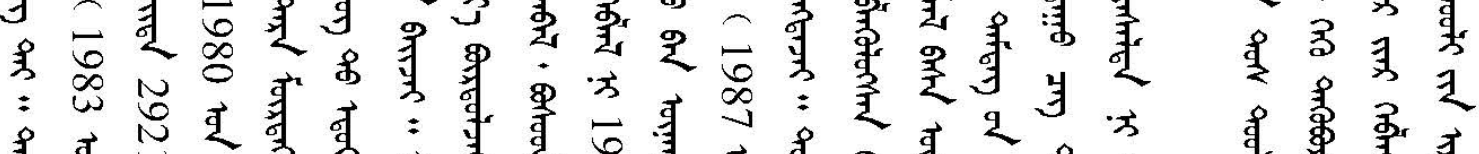

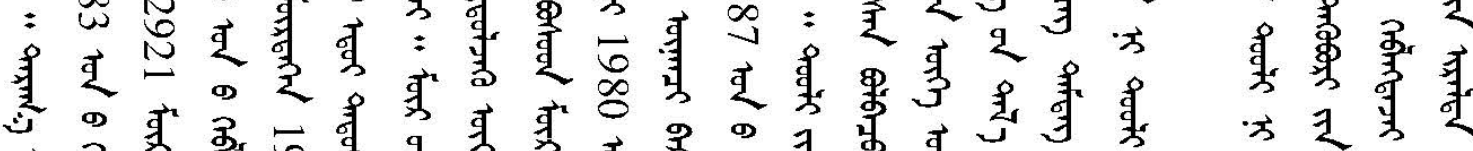

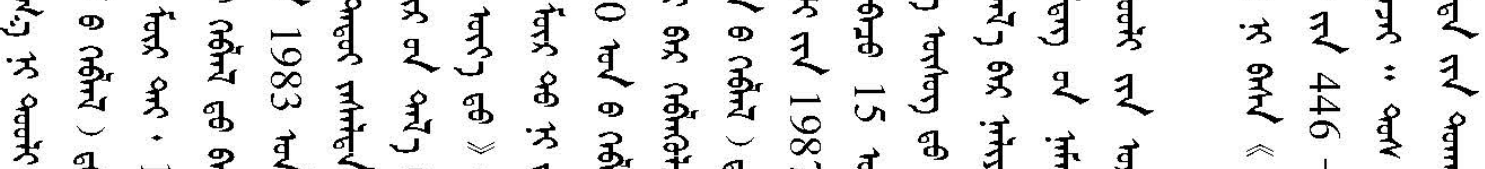

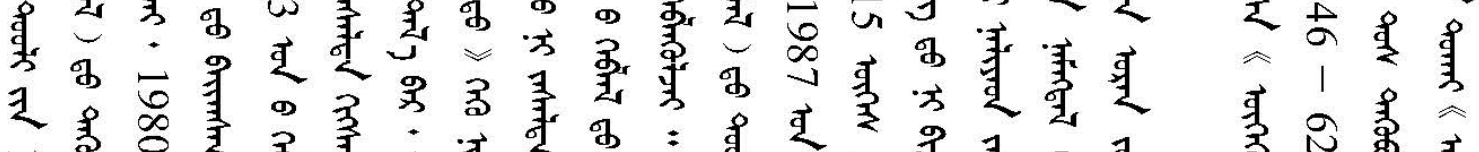

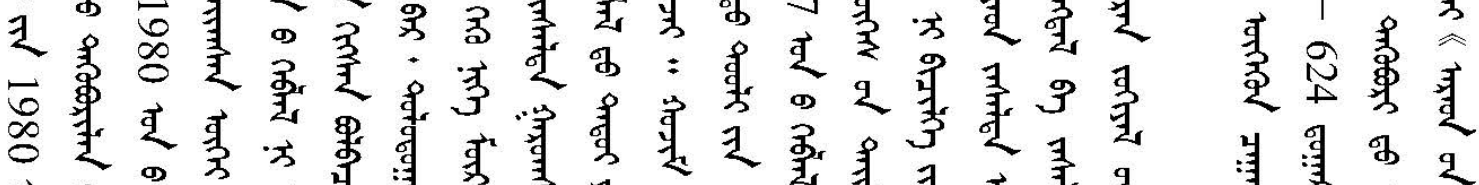

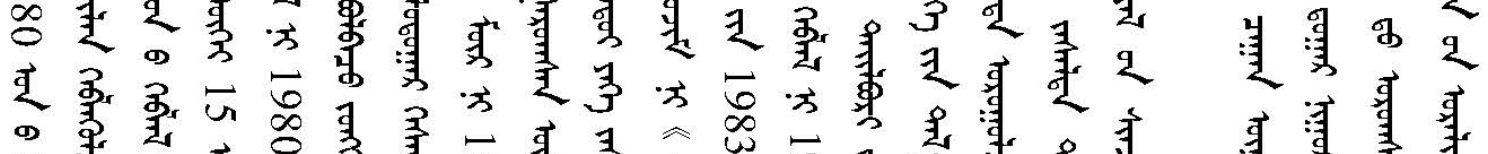

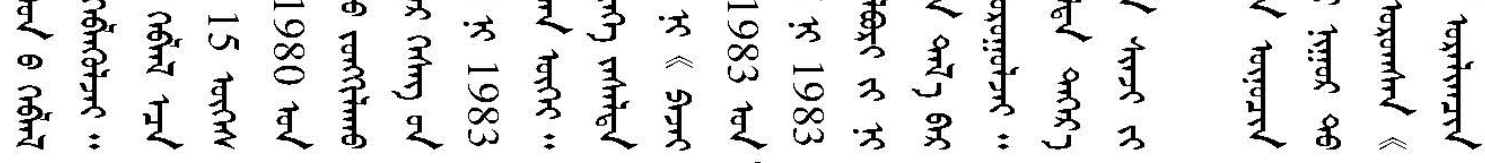




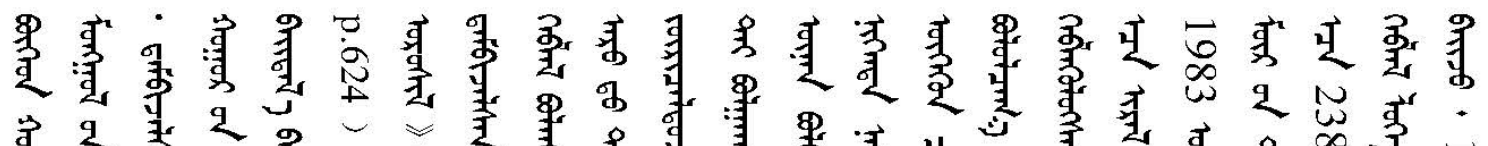

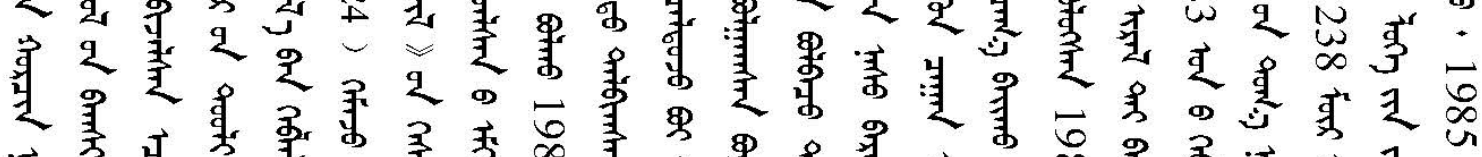

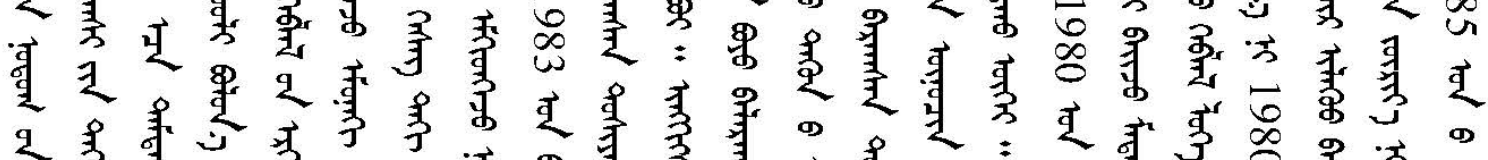

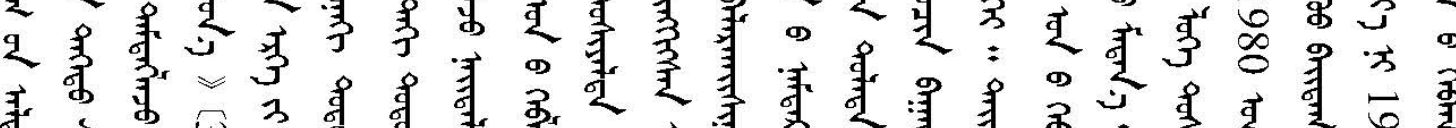

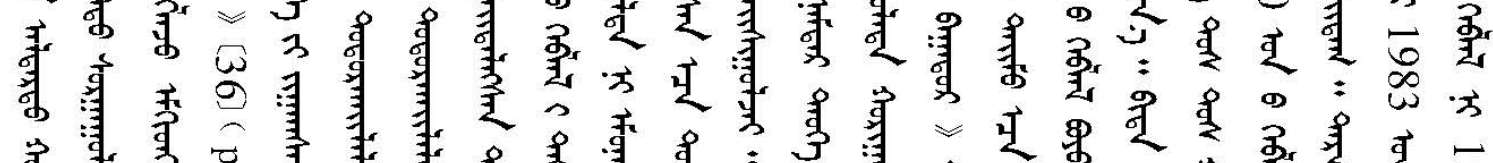

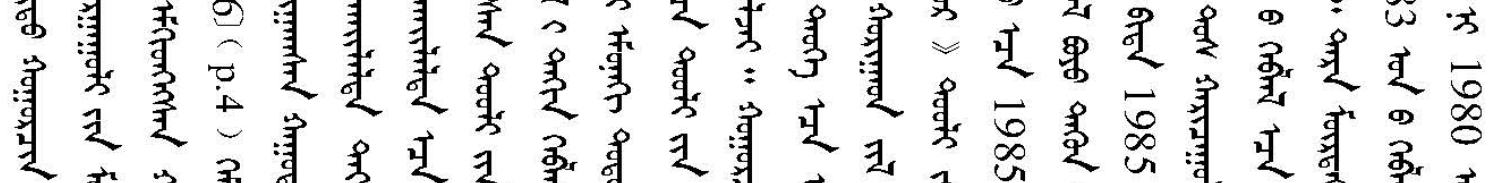

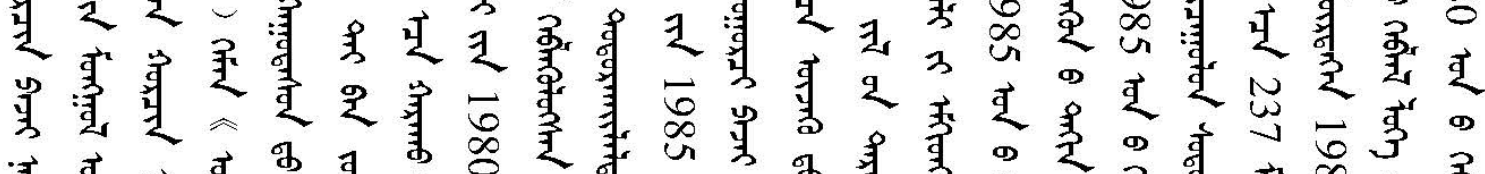

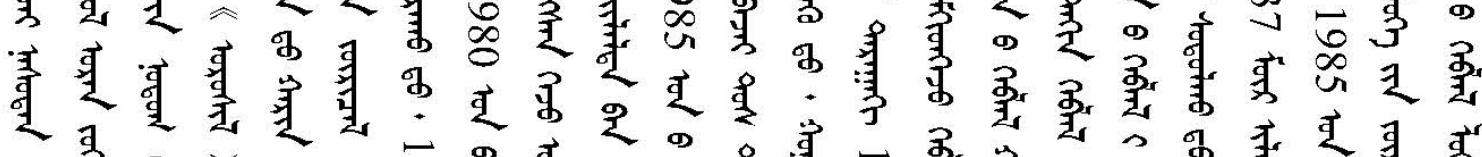

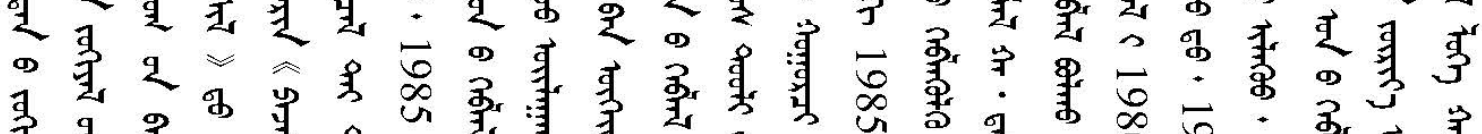

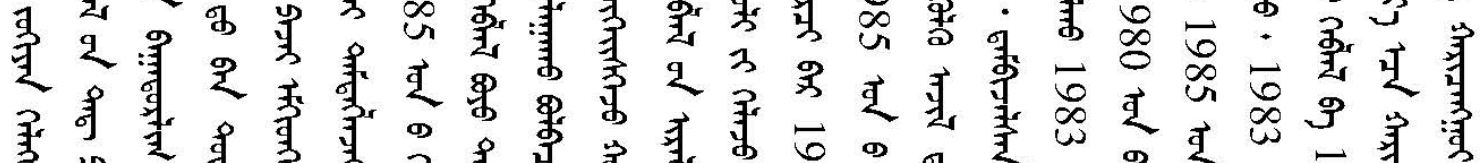

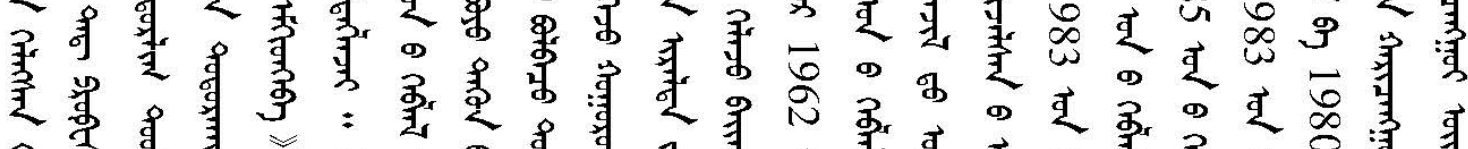

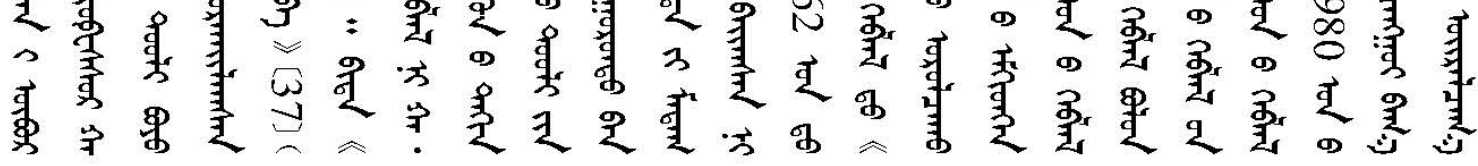

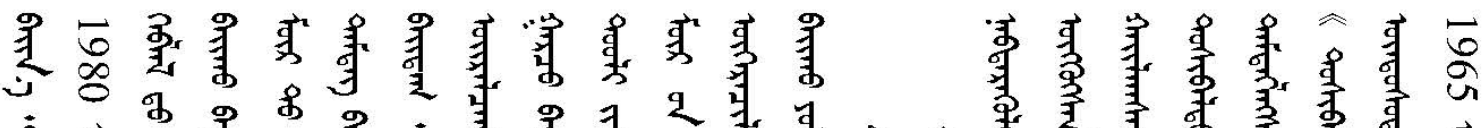

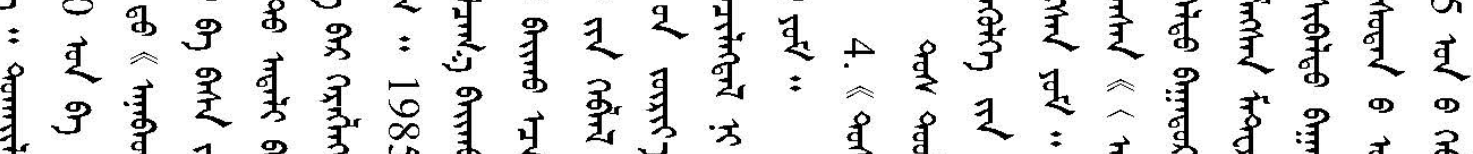

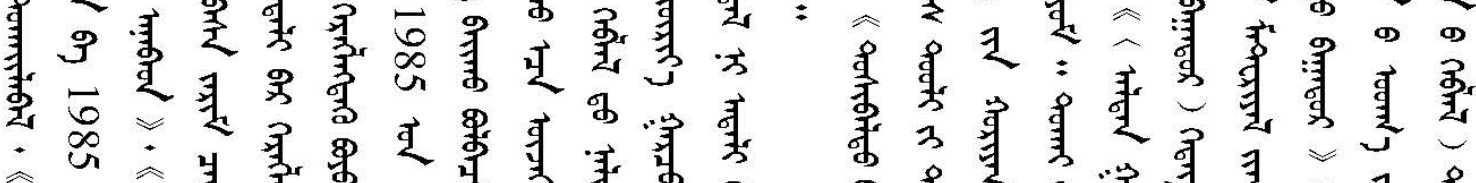

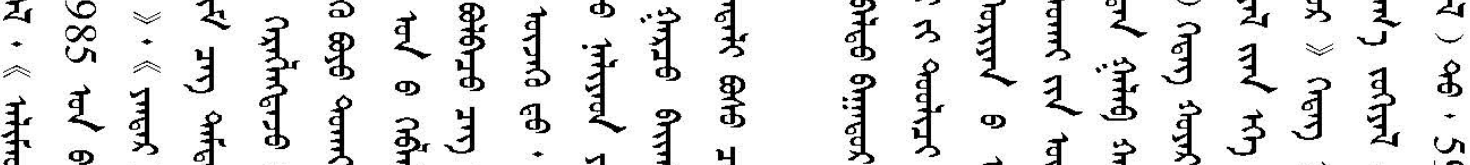

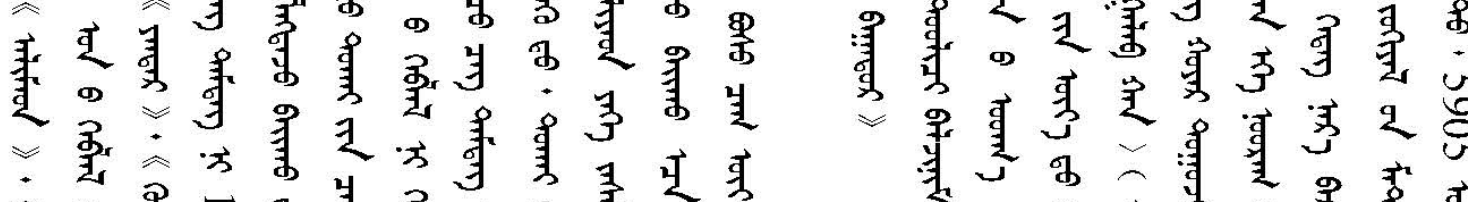

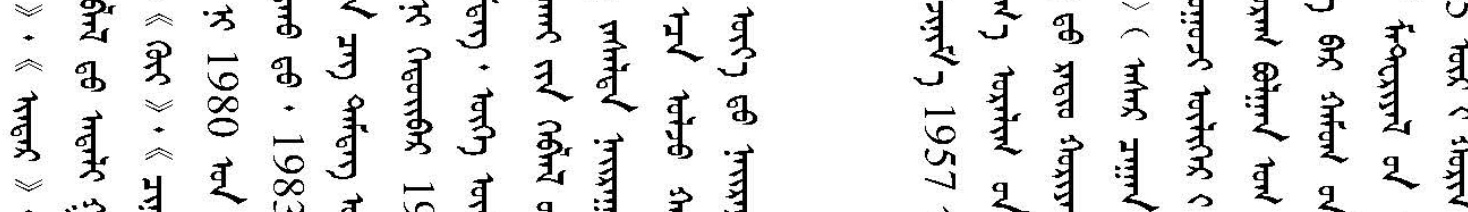

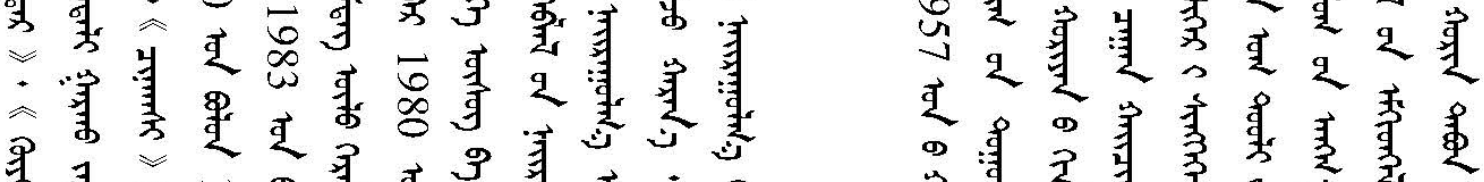

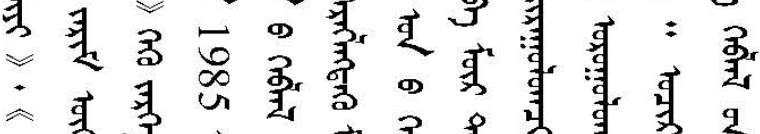

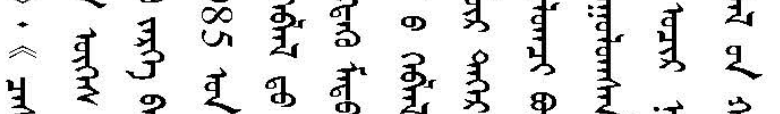

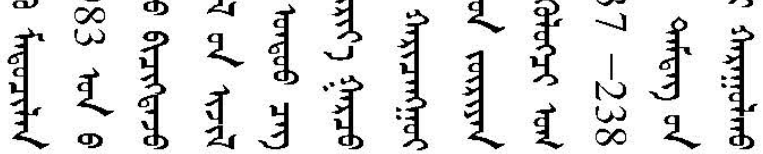

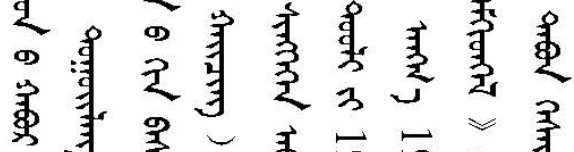
क्व क

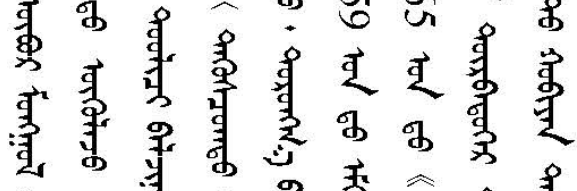

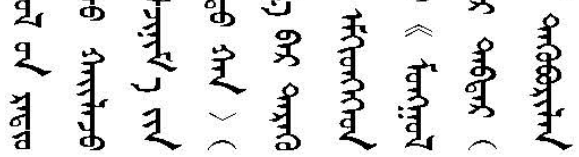




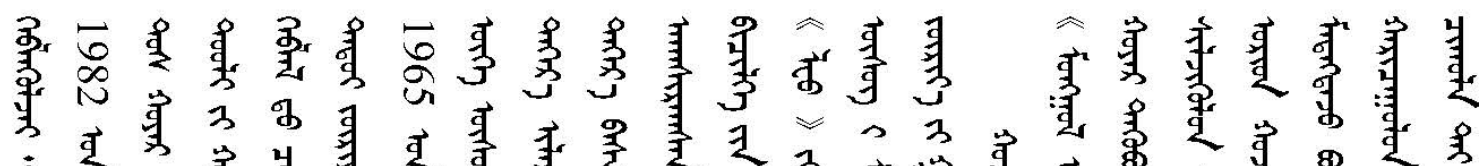

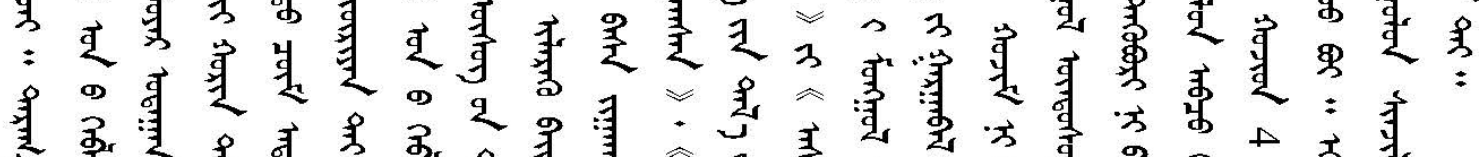

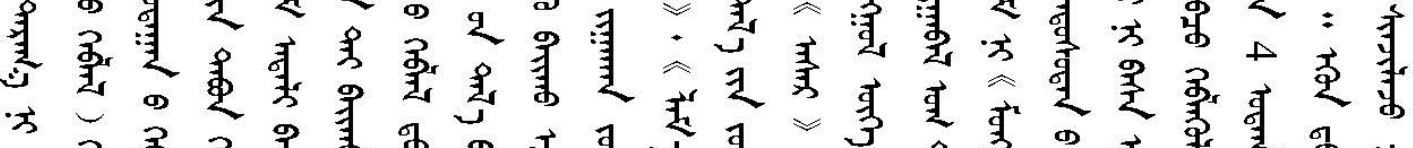

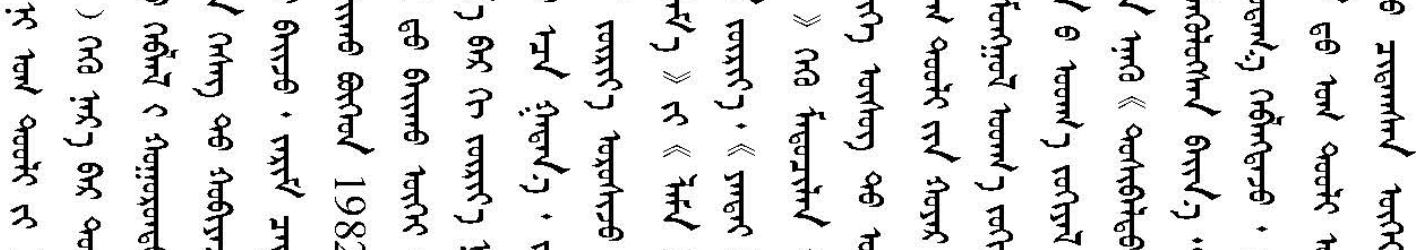

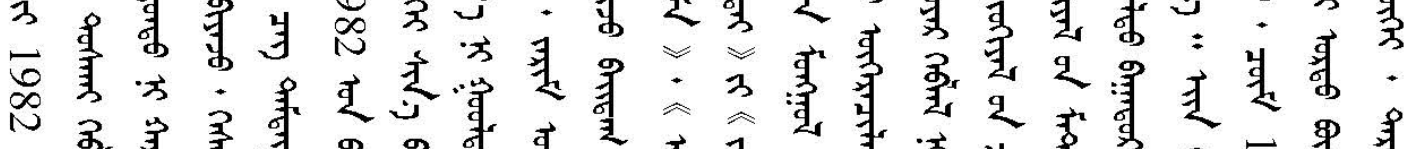

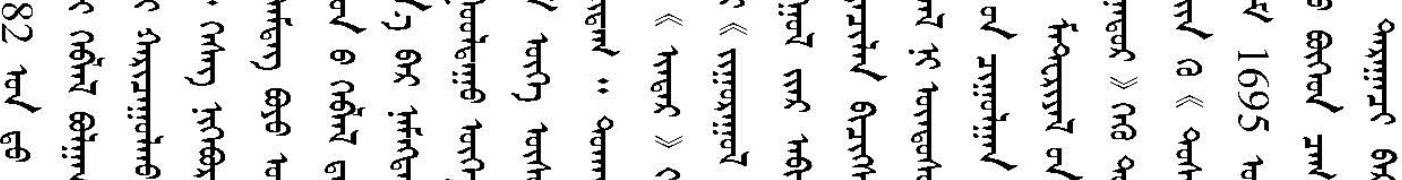

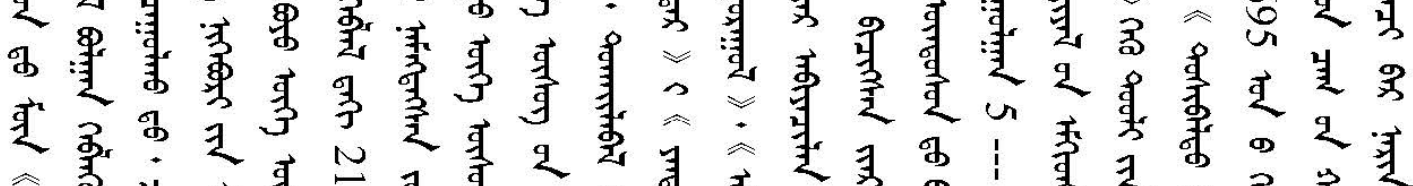

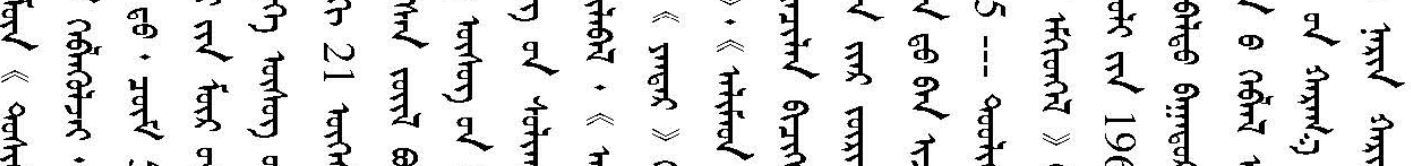
季:

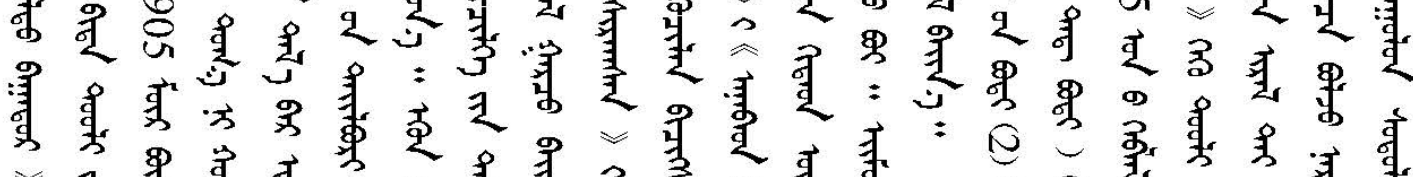

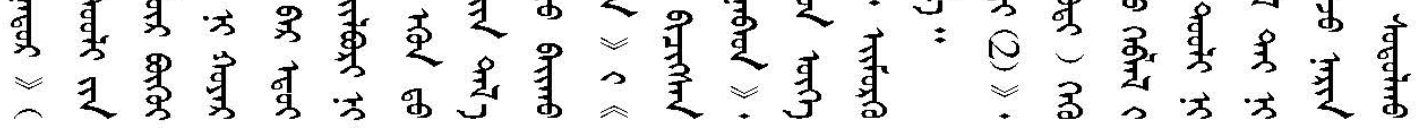

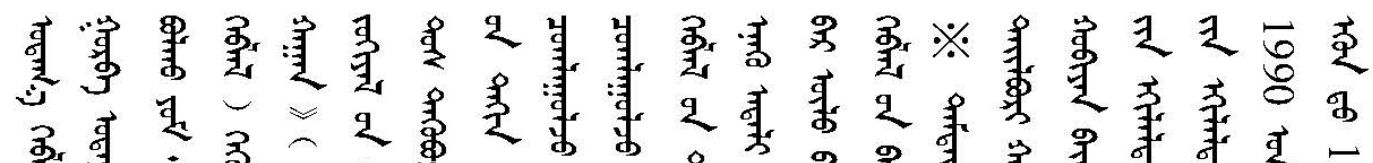

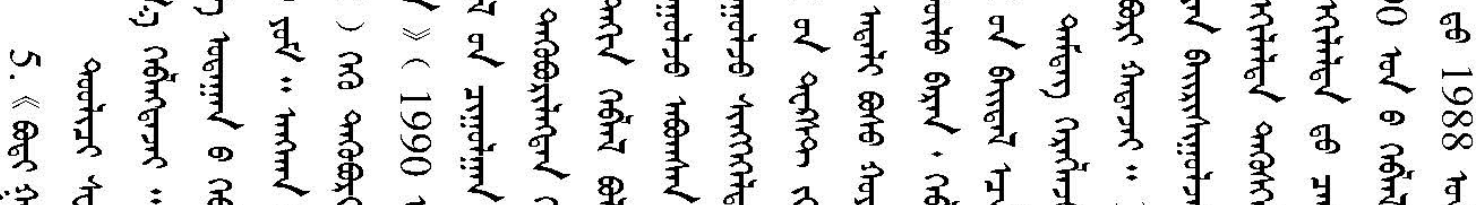

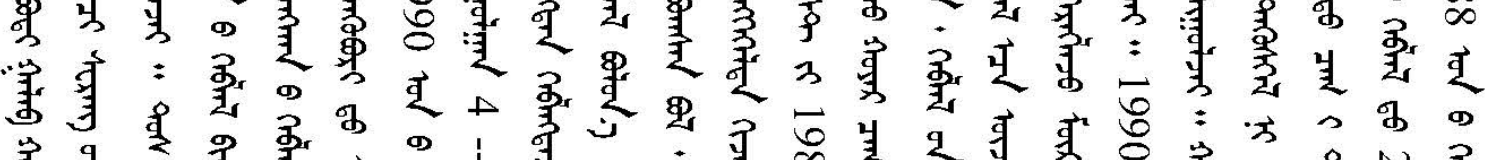

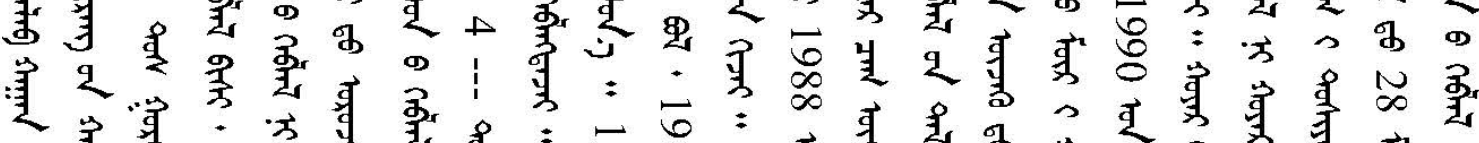

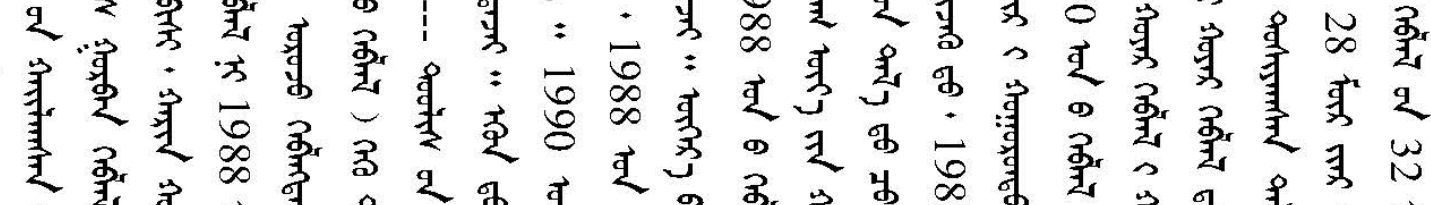

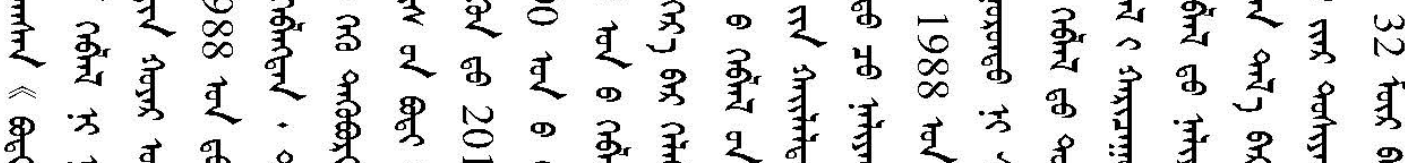

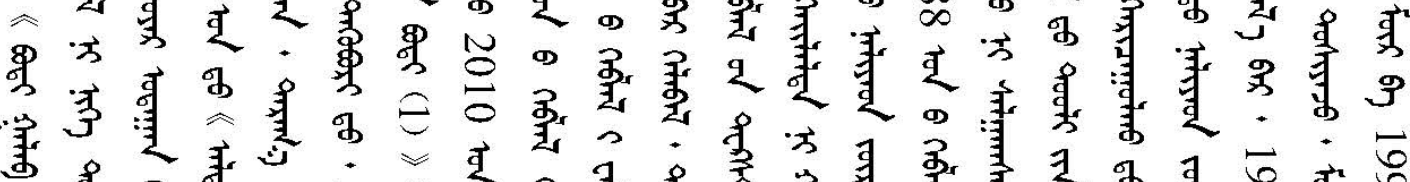

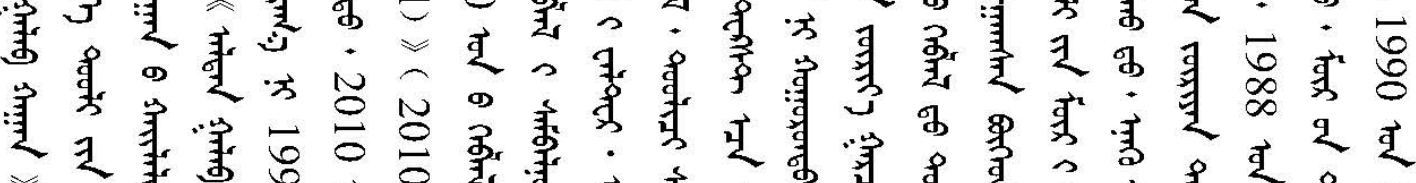

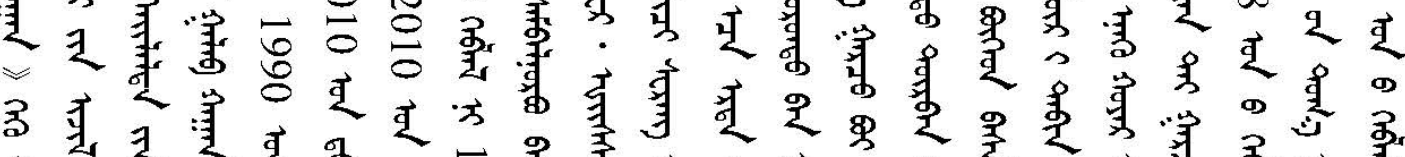

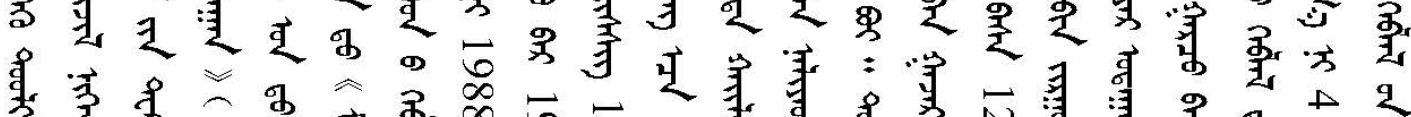

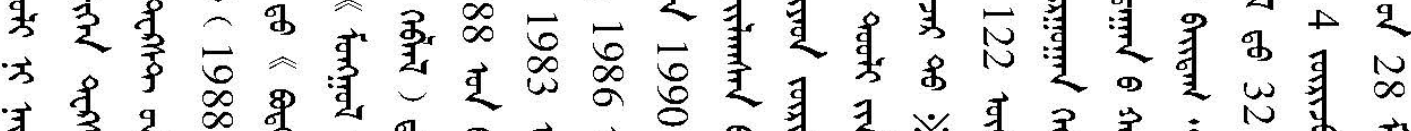

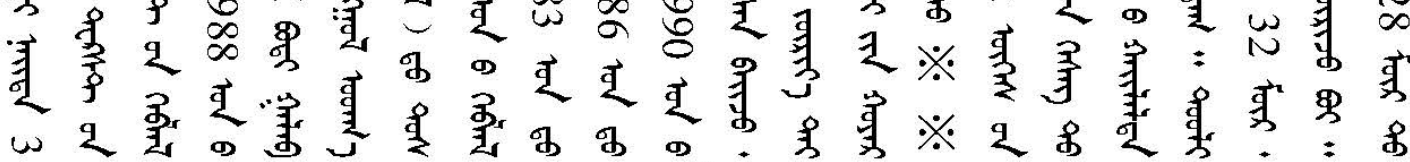




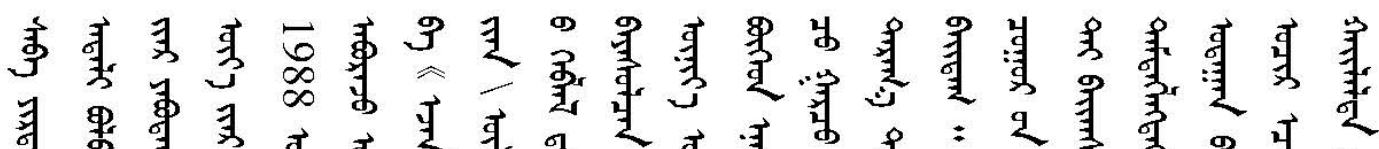

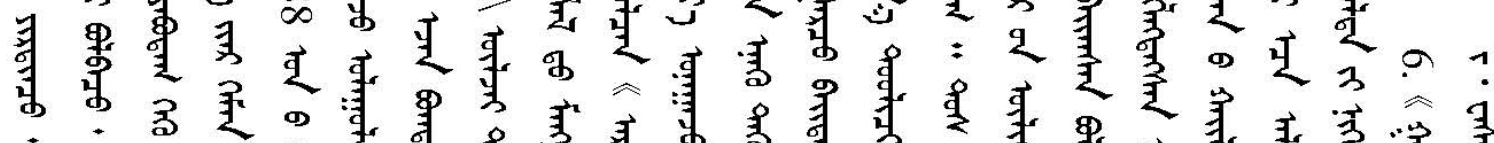

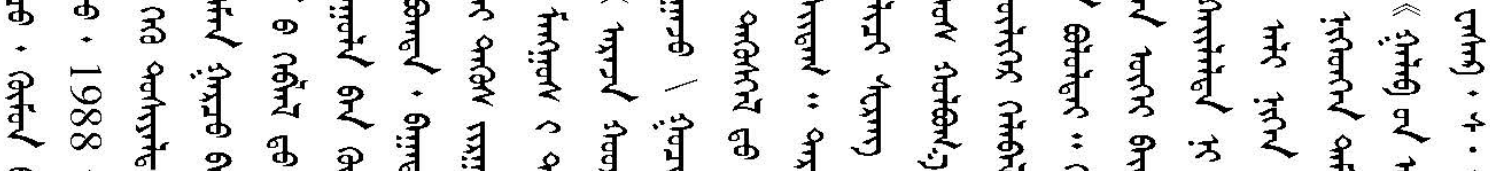

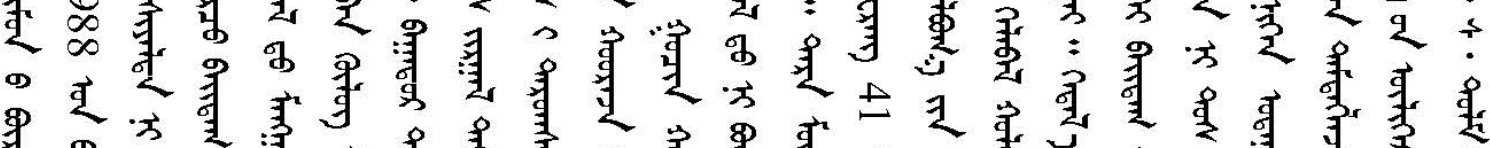

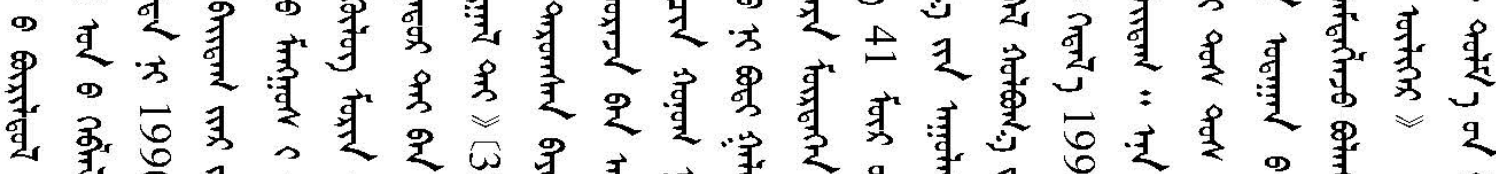

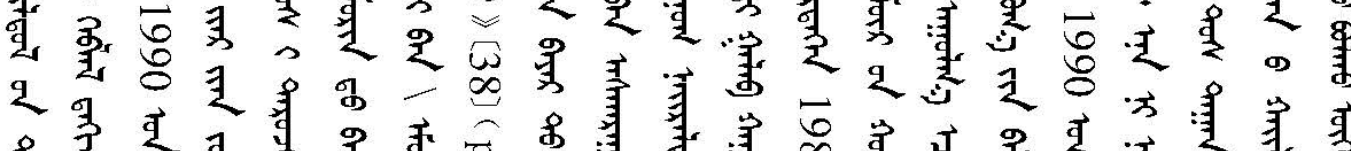

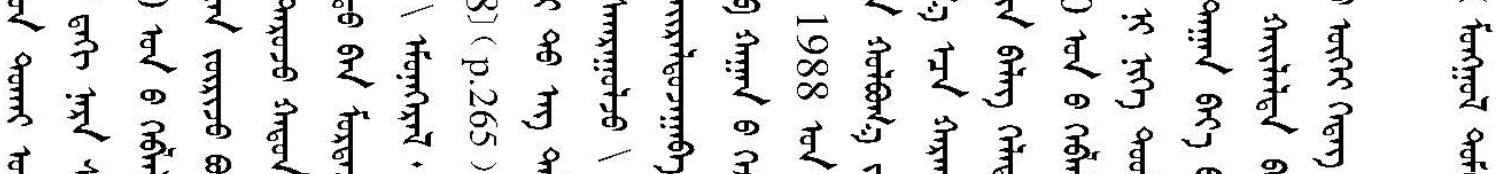

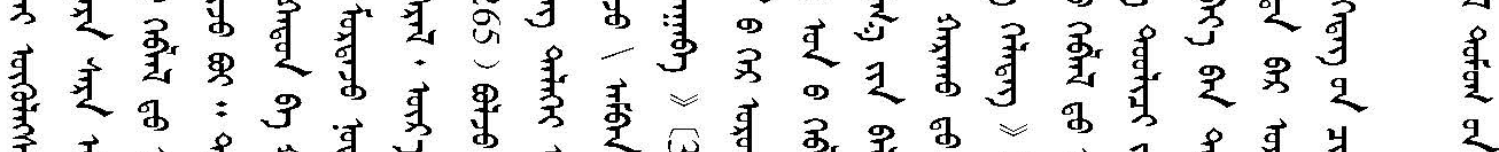

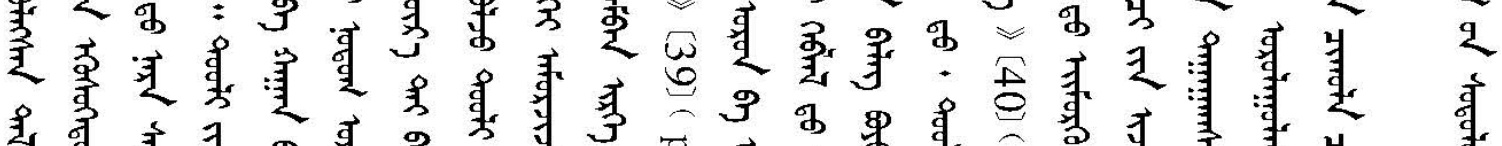

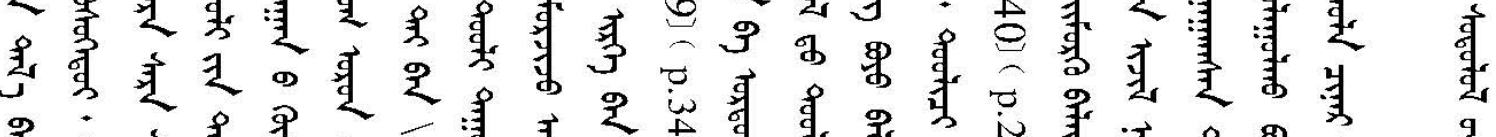

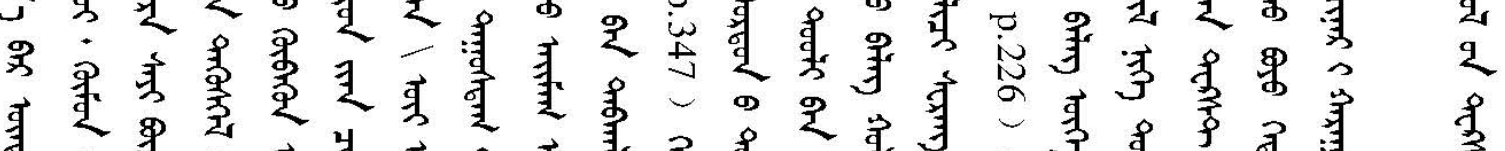

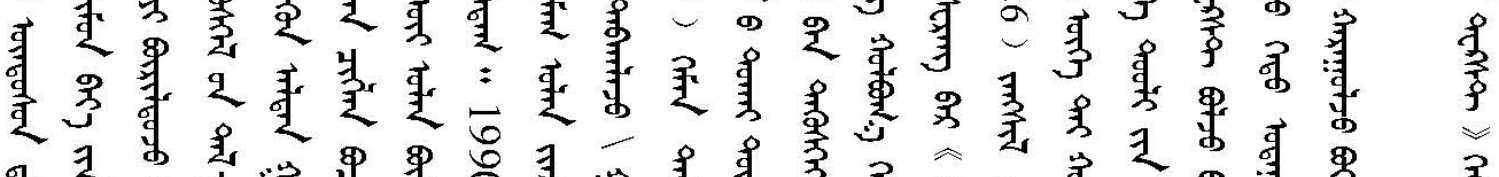

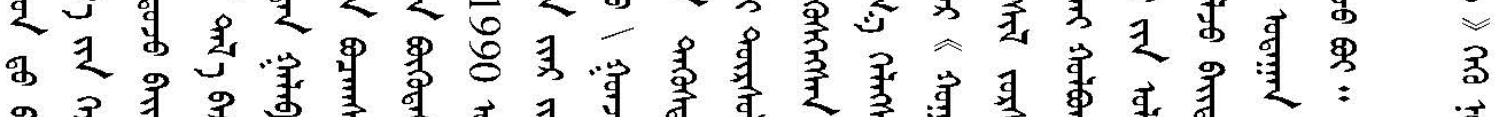

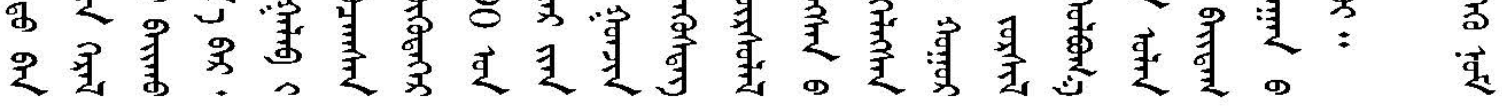

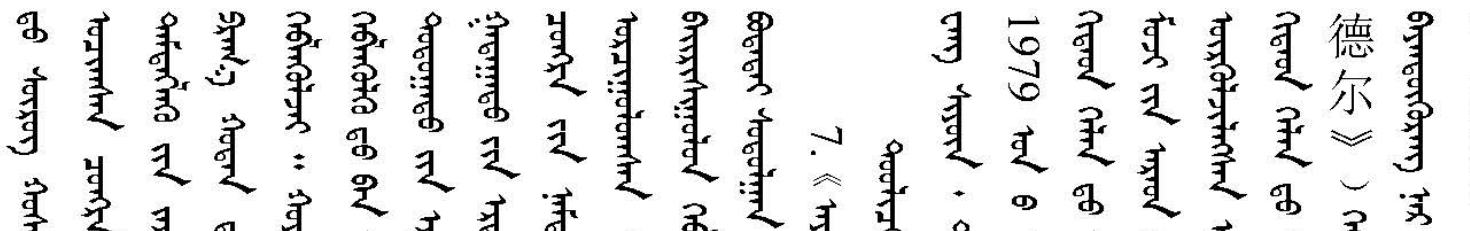

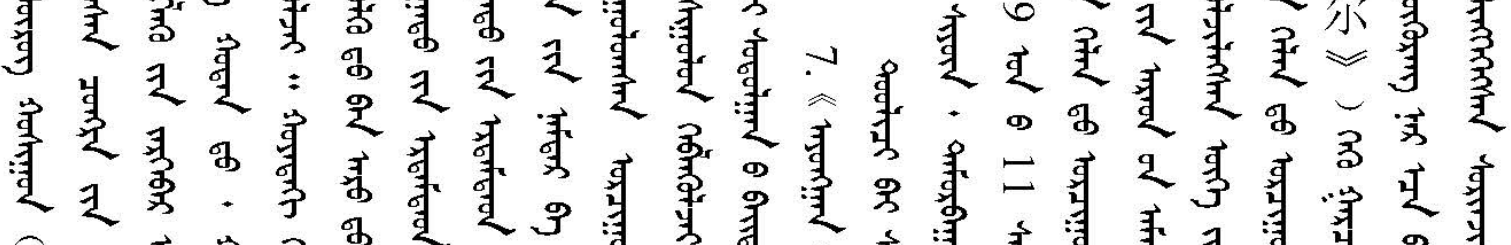

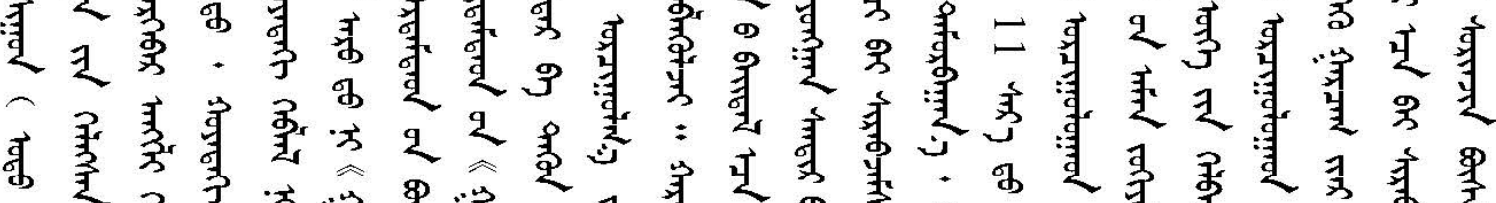
1

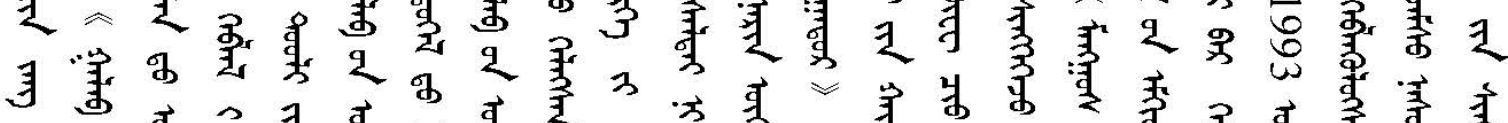

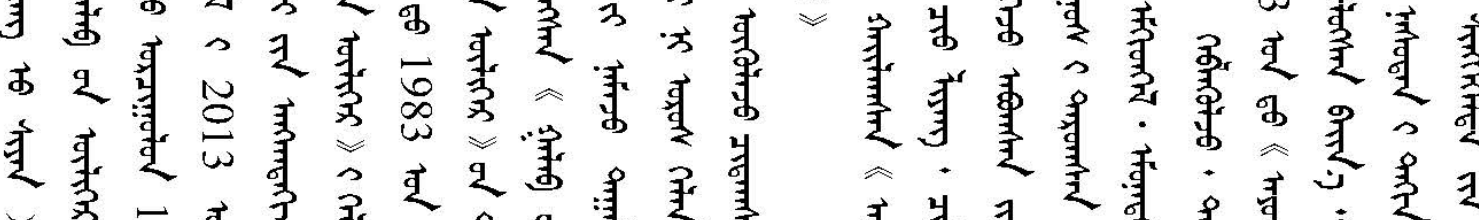

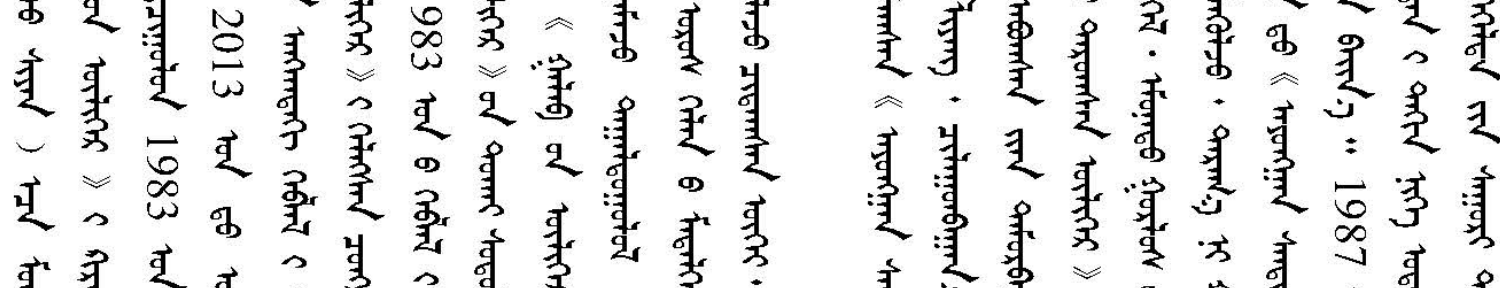

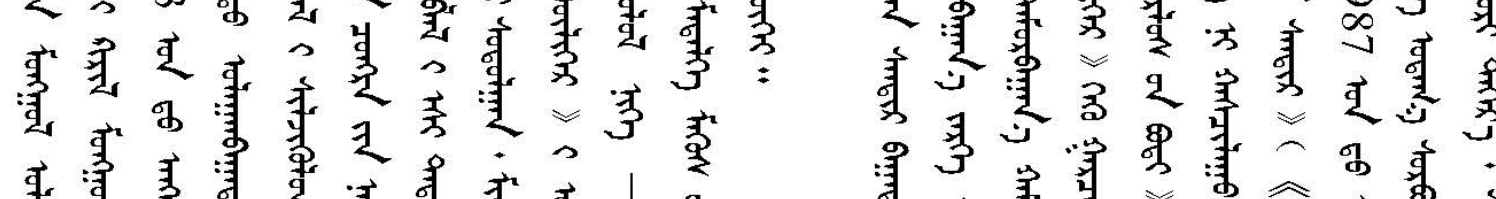

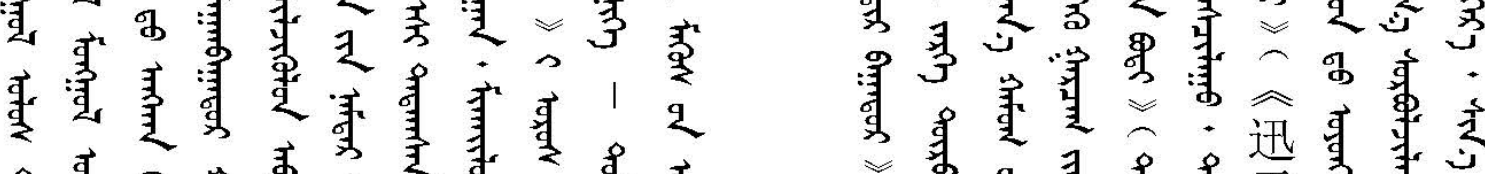

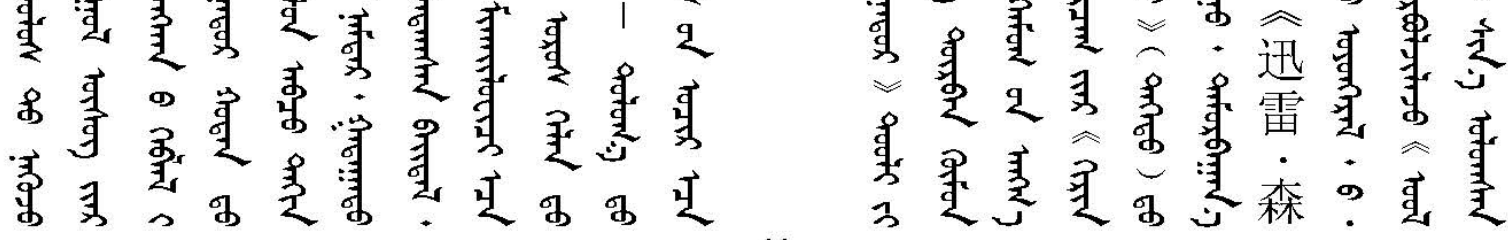




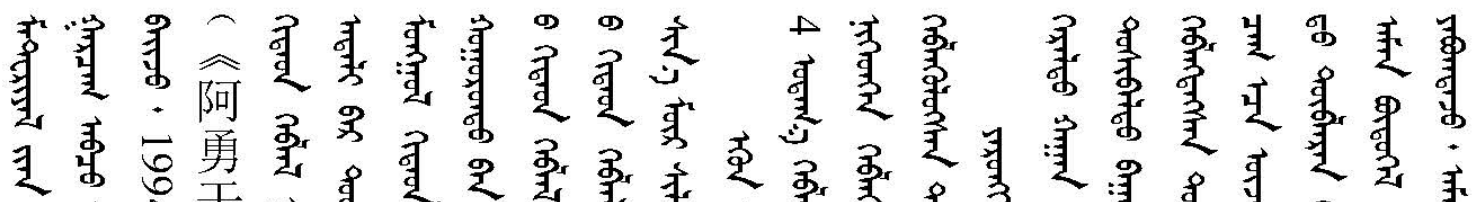

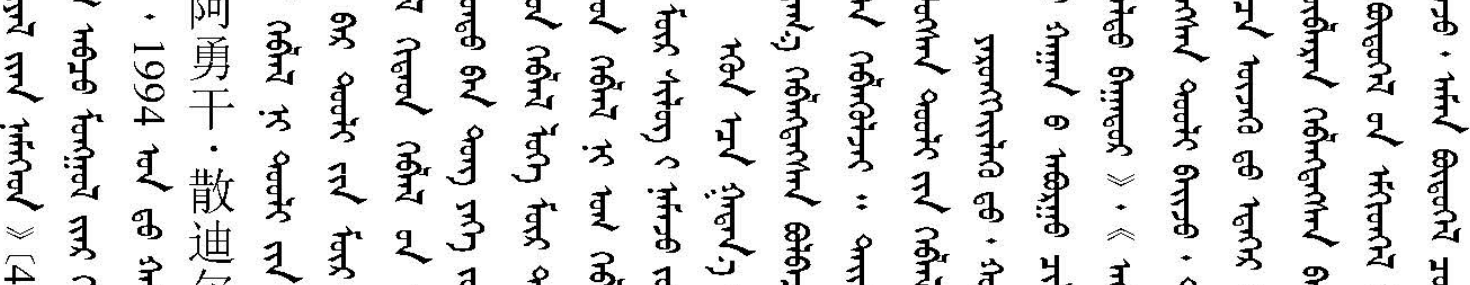

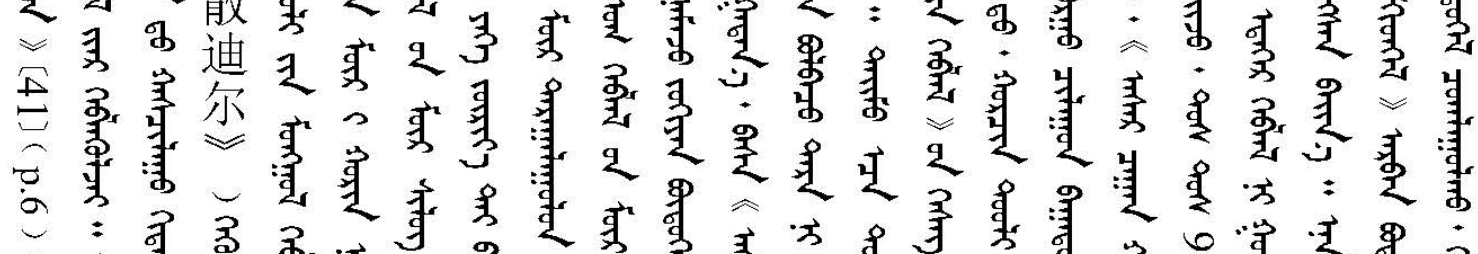

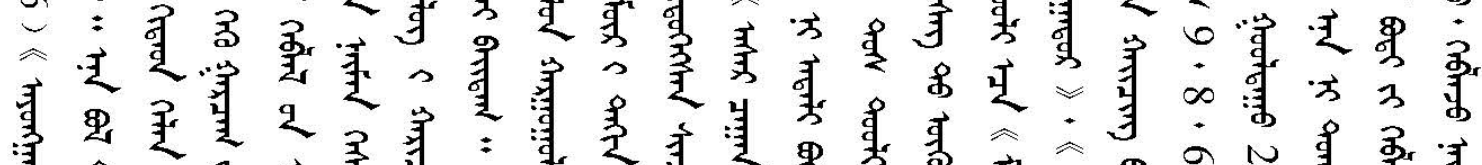

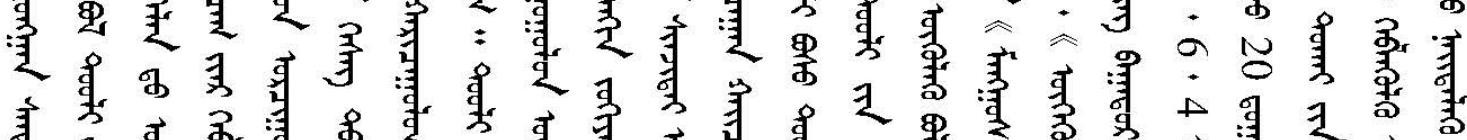

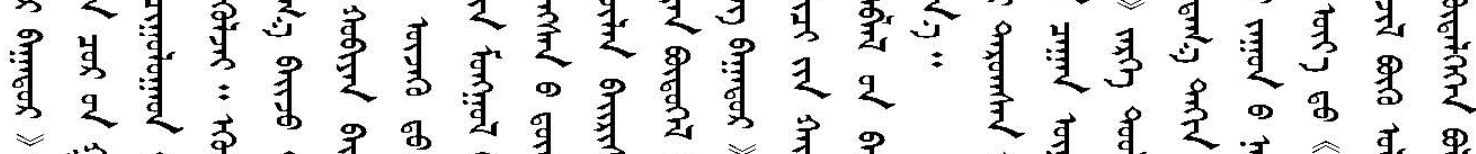

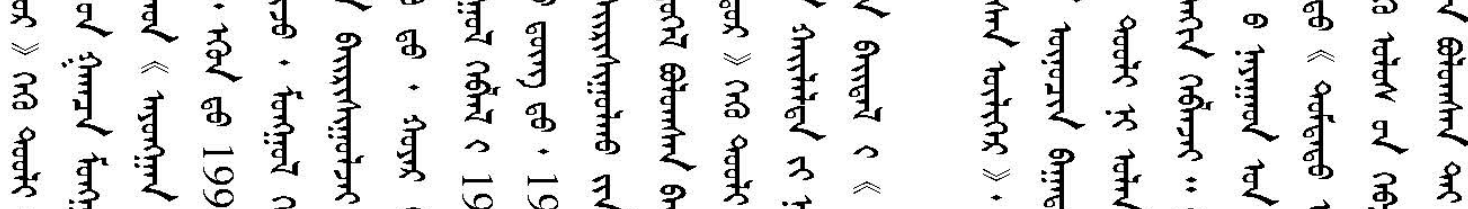

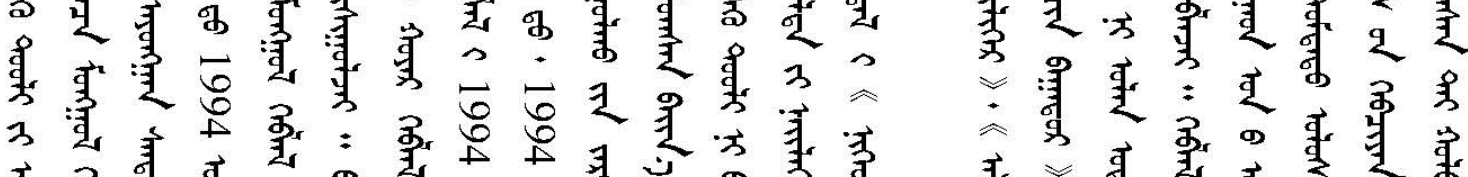

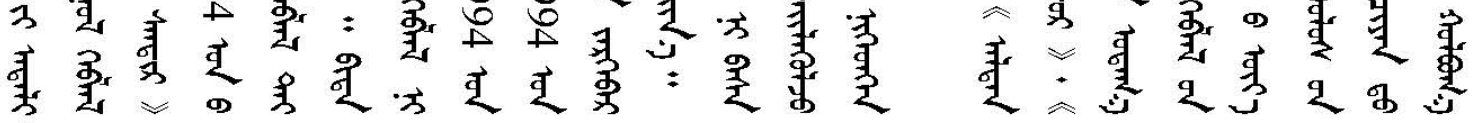

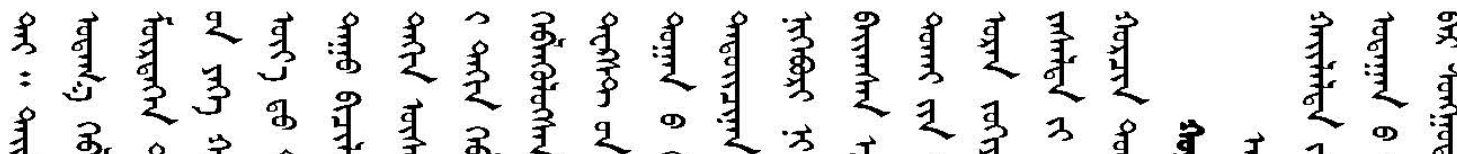

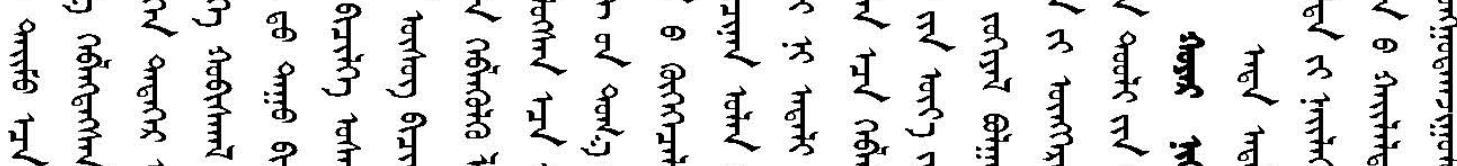

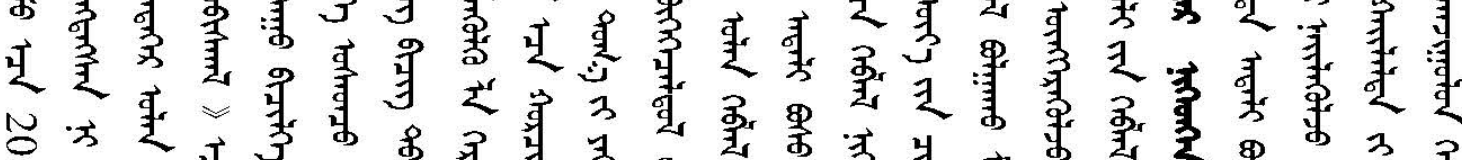

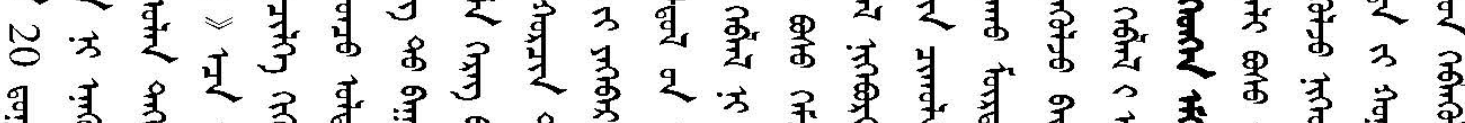

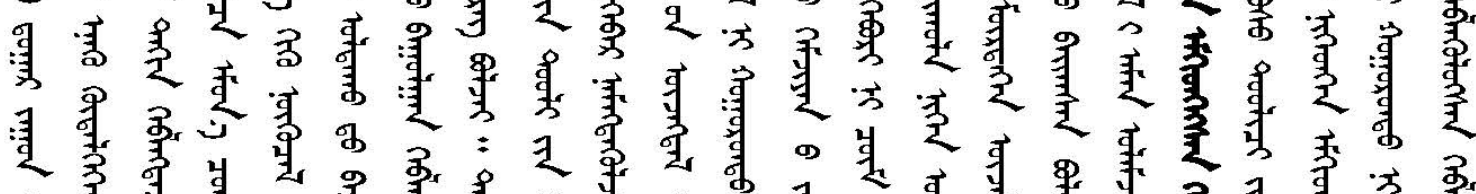

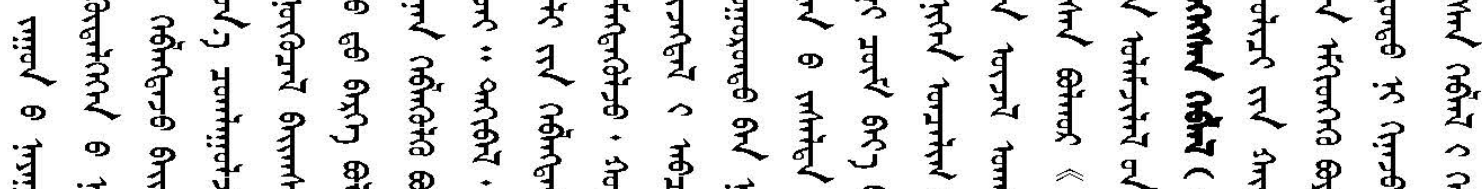

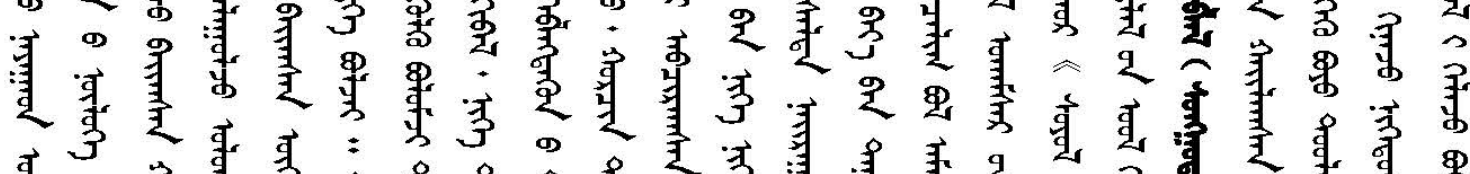

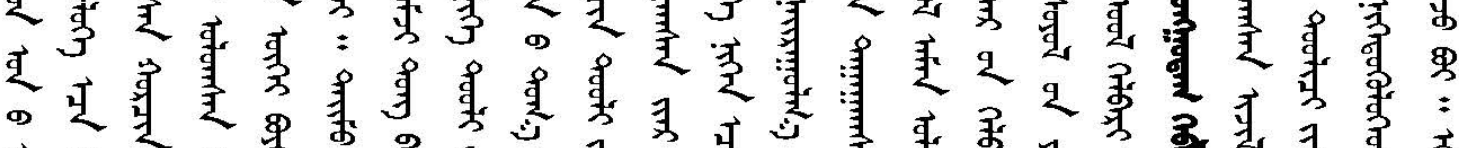

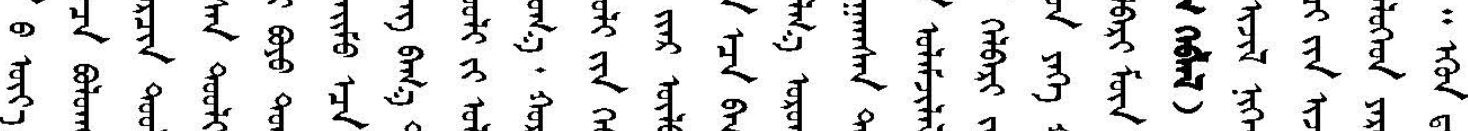

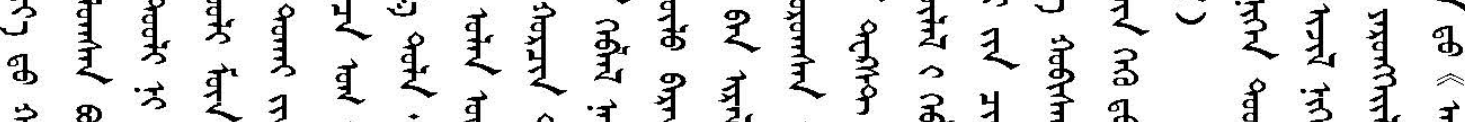

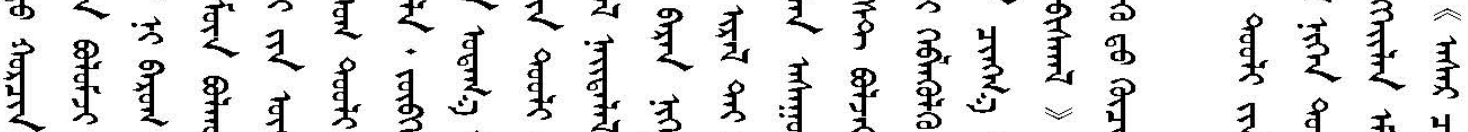

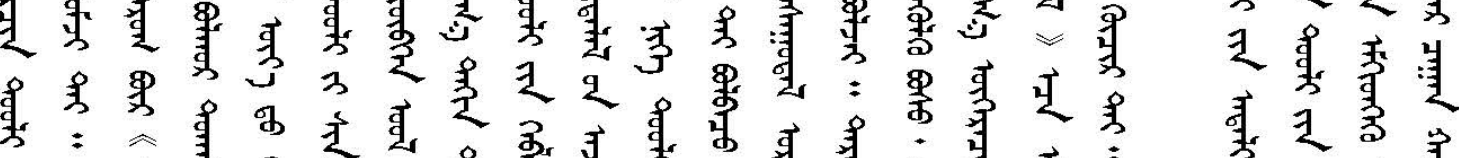

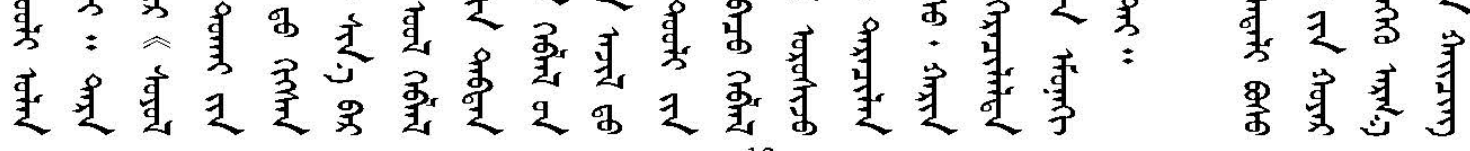




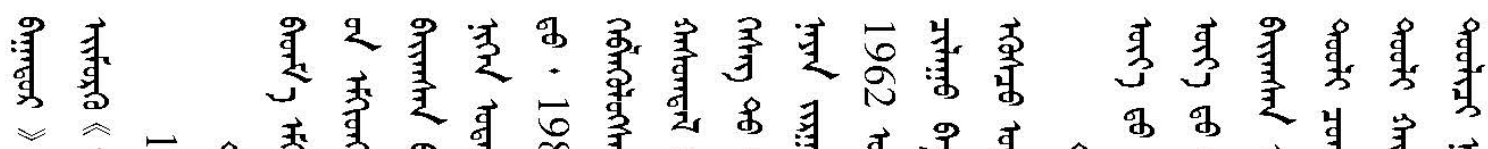

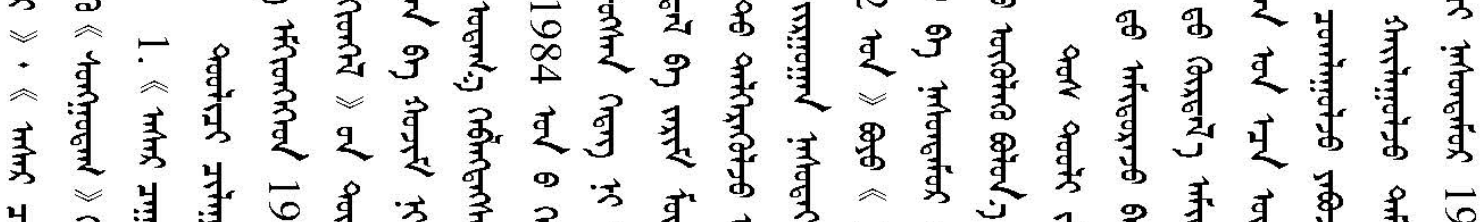

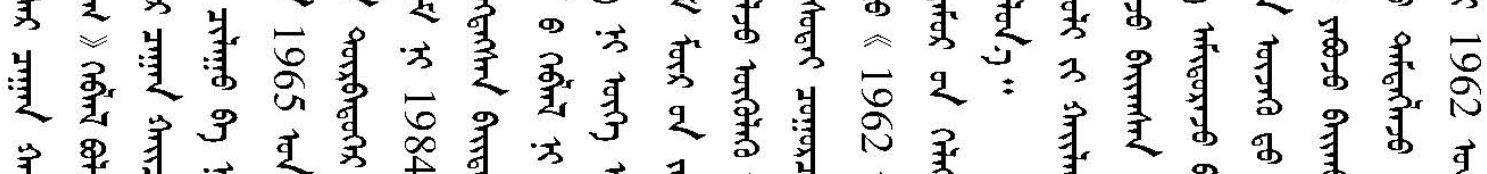

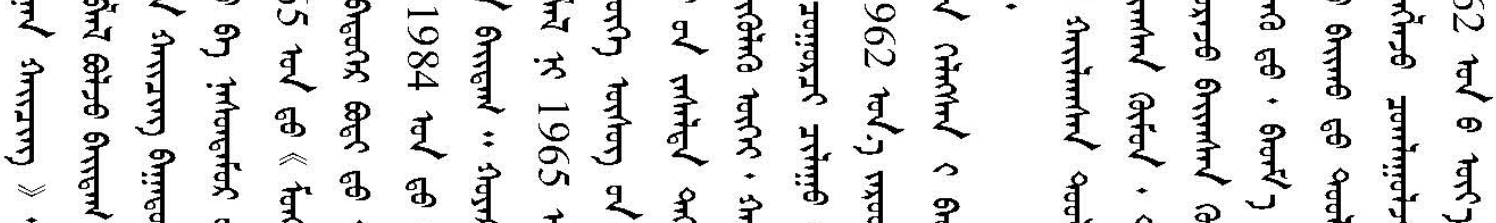

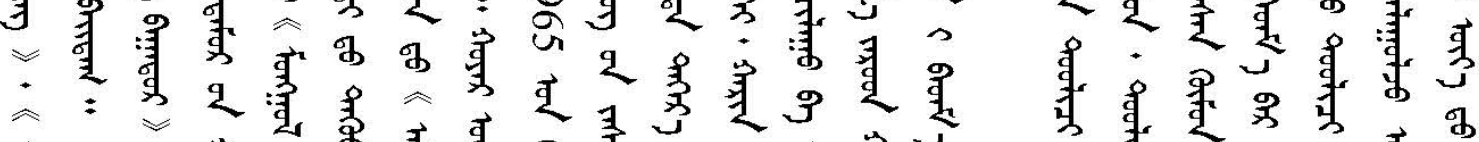

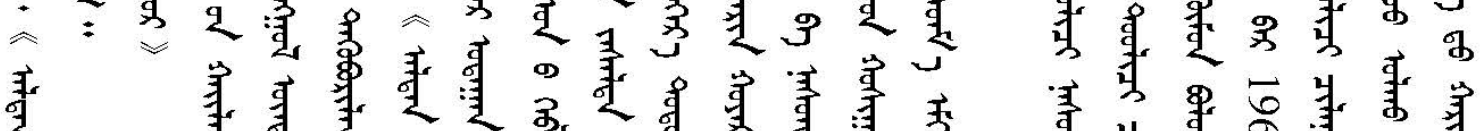

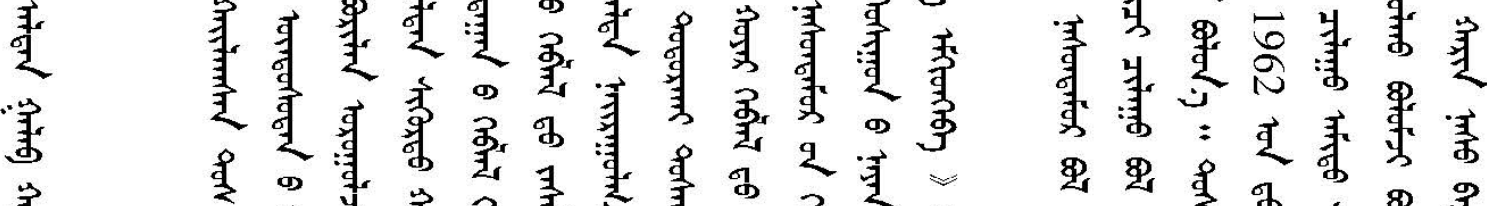

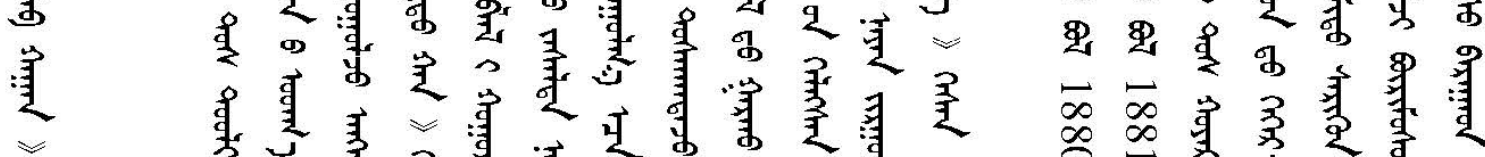

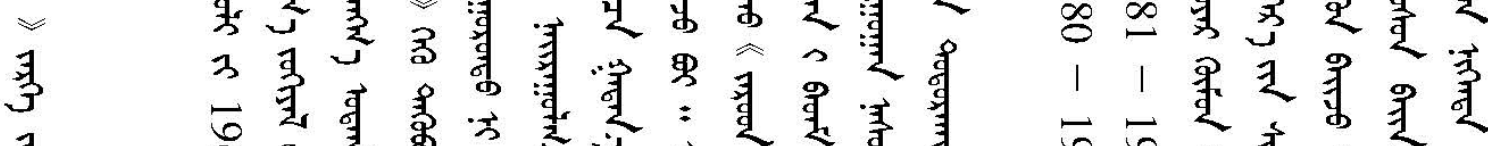

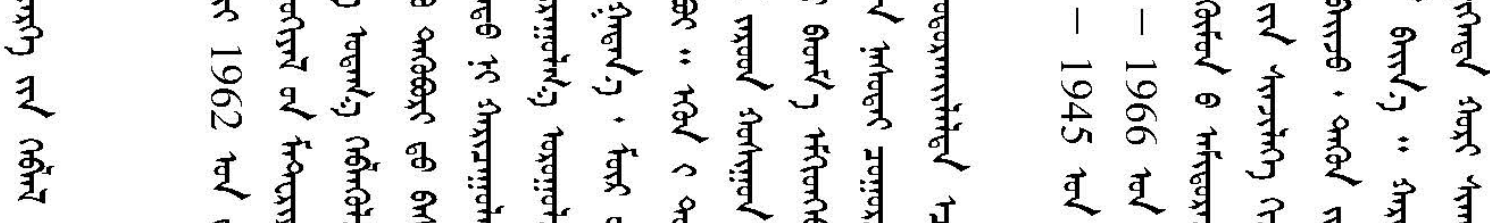

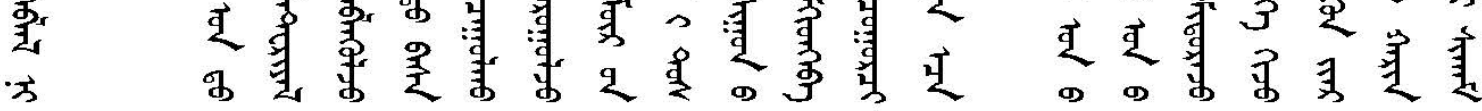

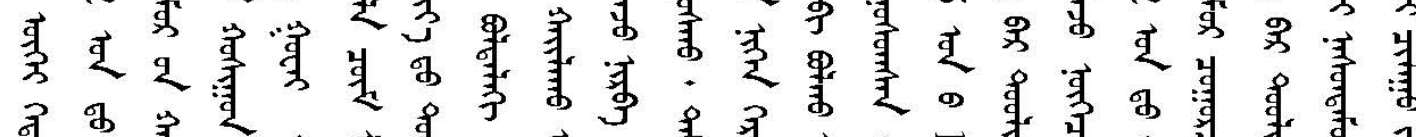

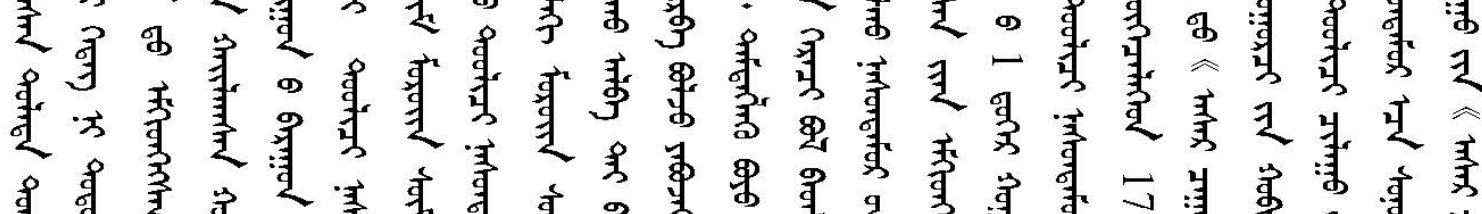

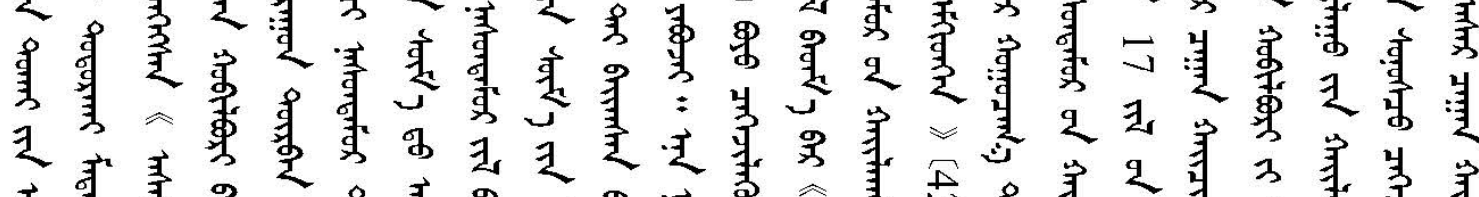

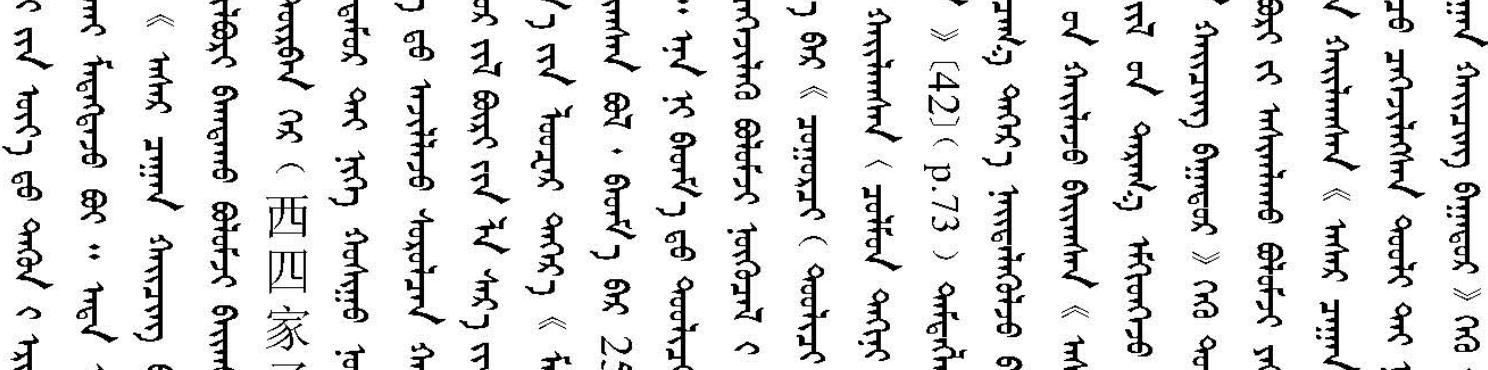

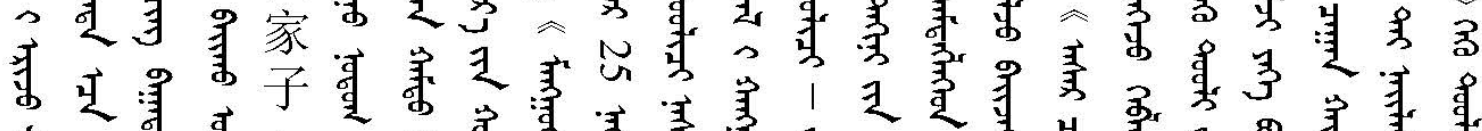

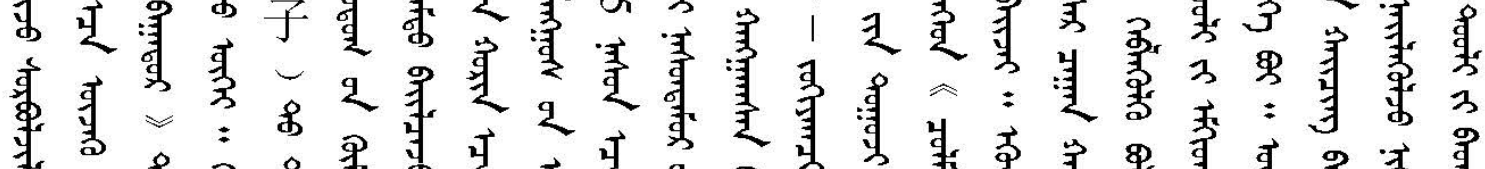

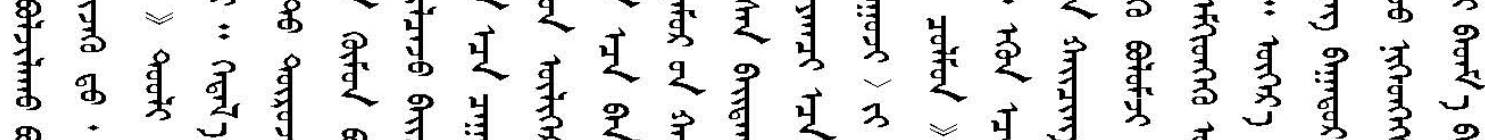

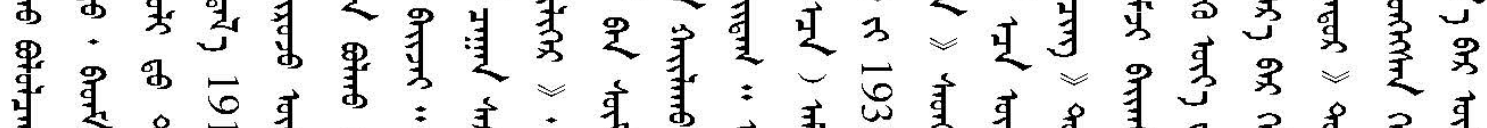

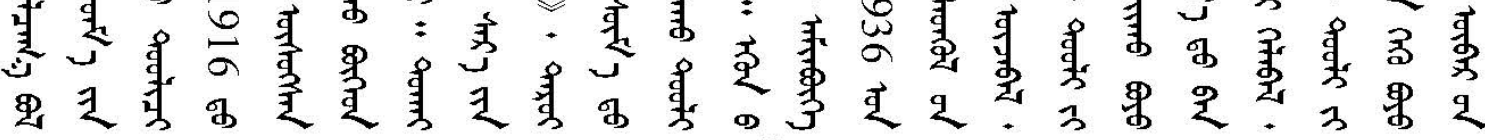




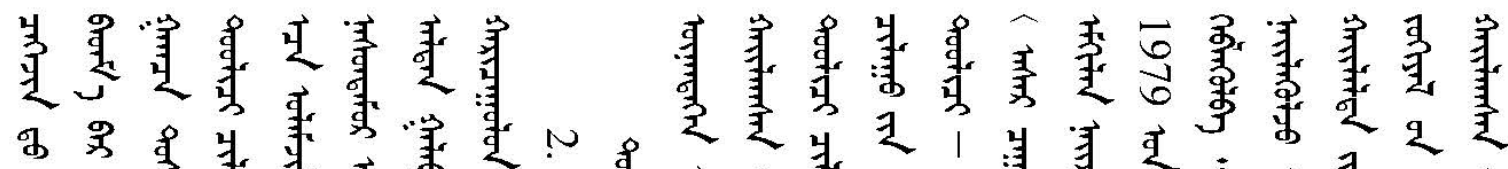

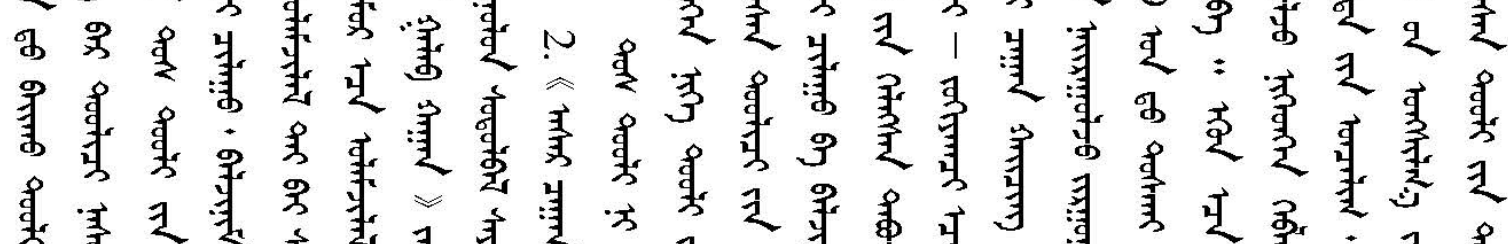

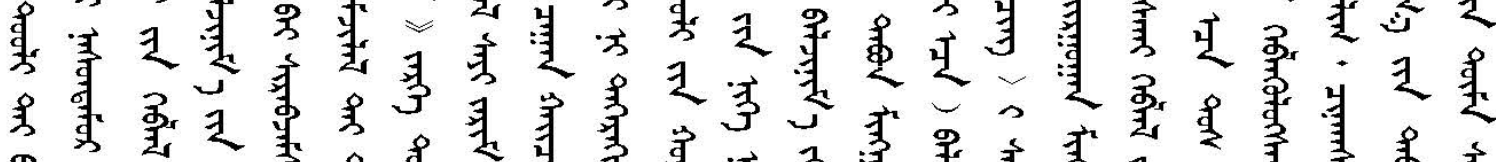

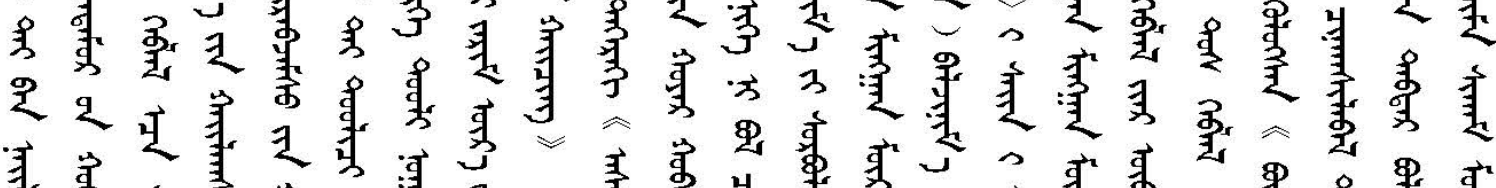

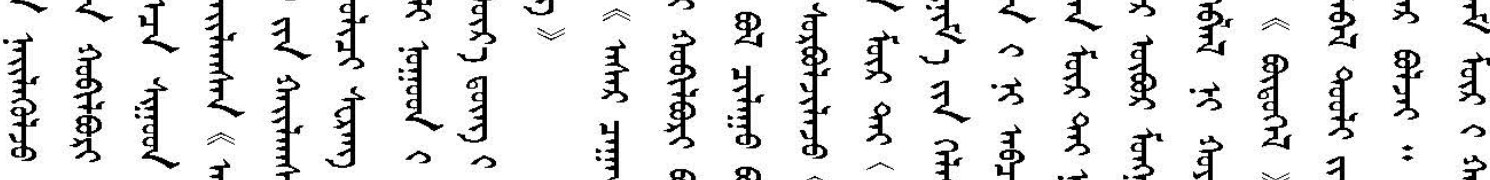

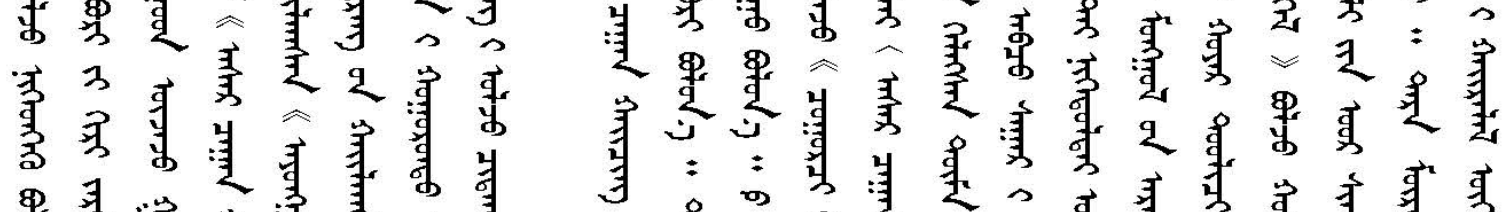

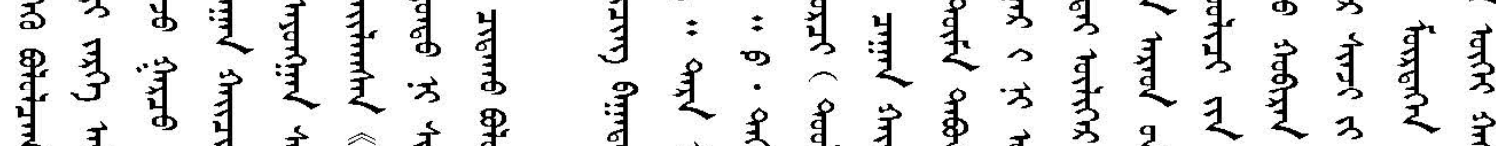

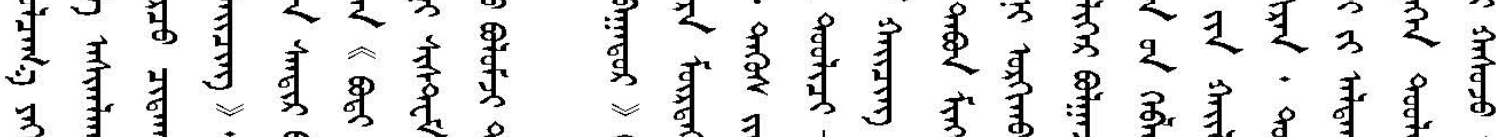

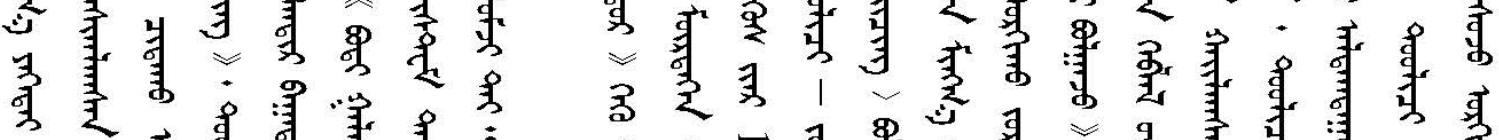

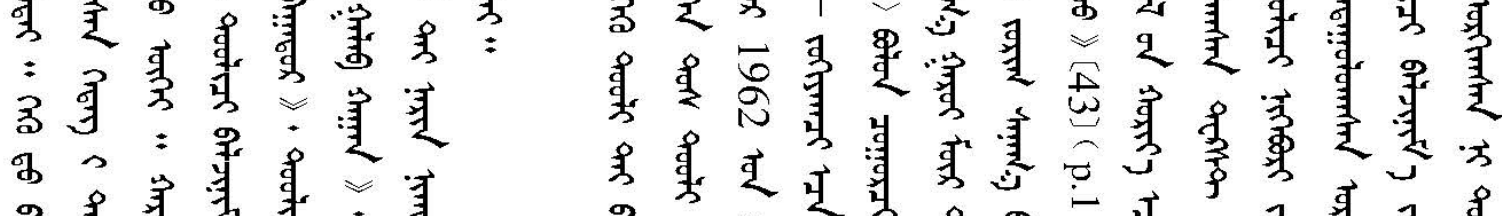

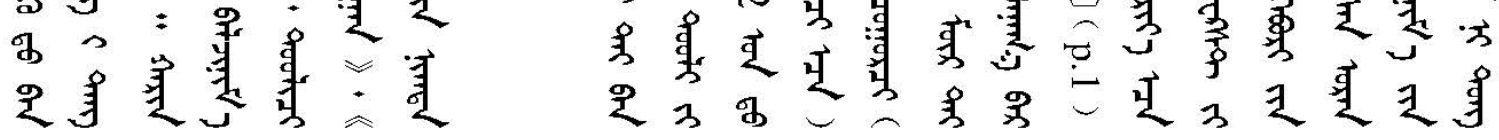

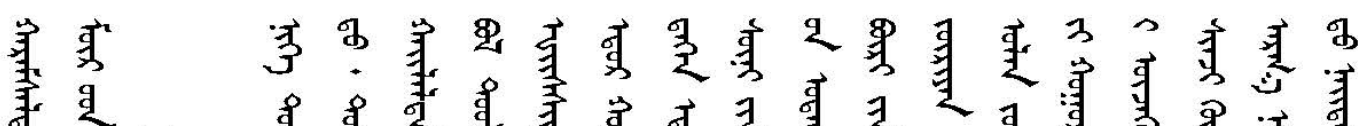

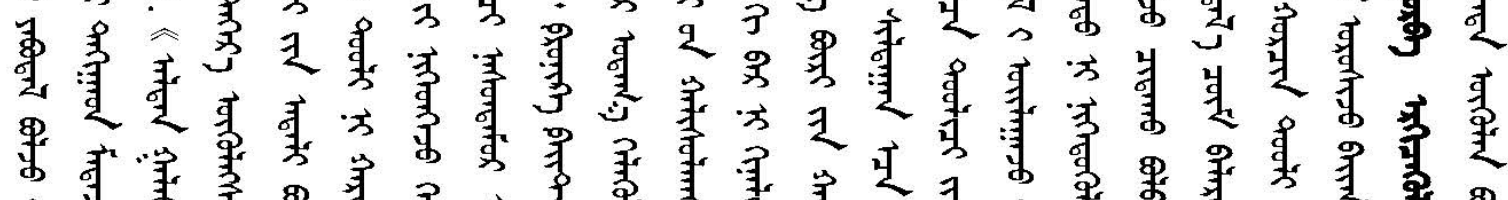

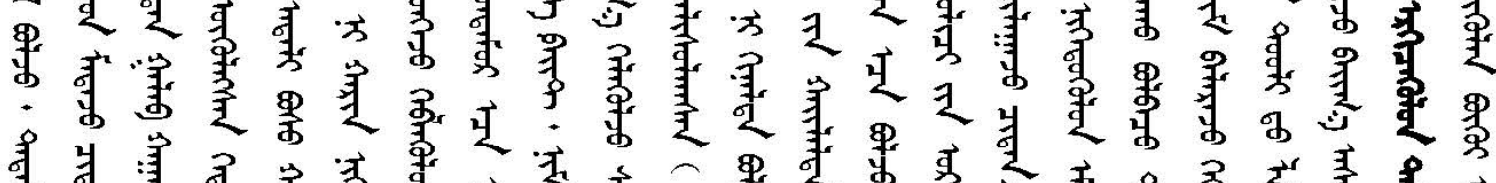

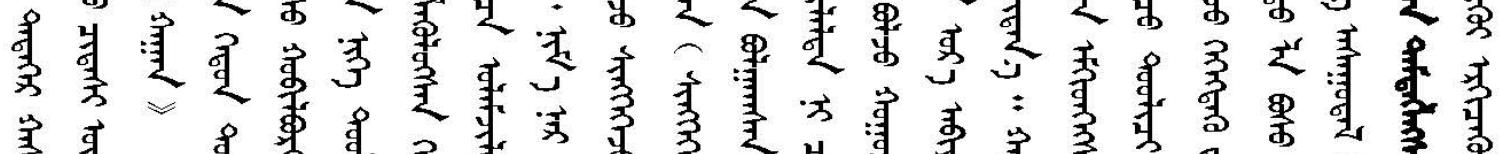

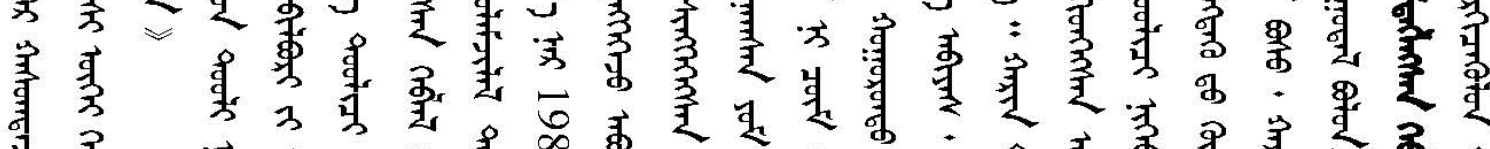

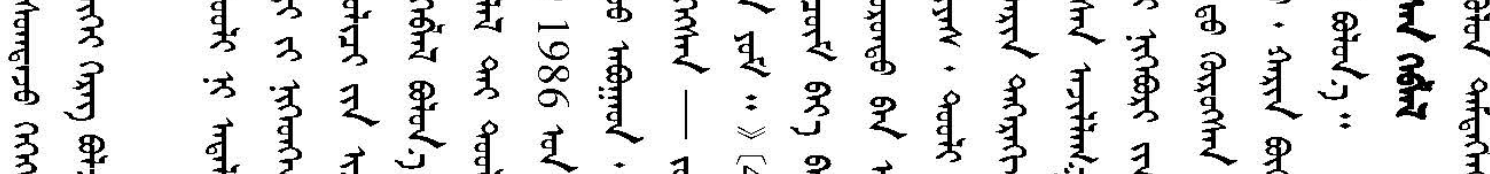

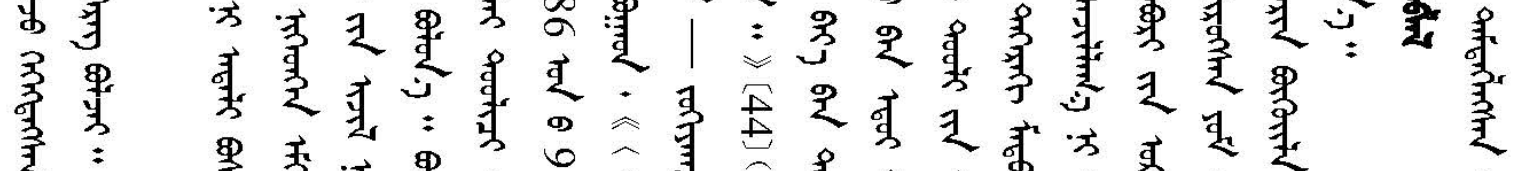

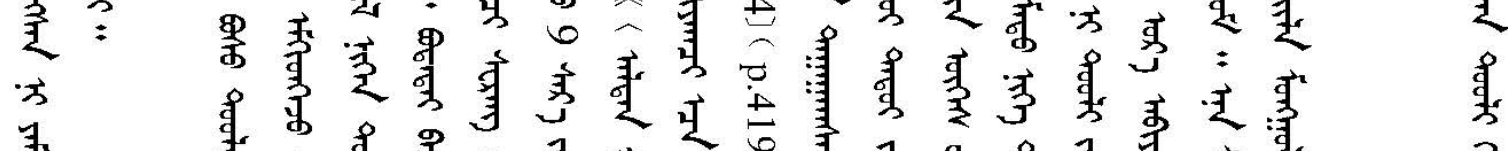

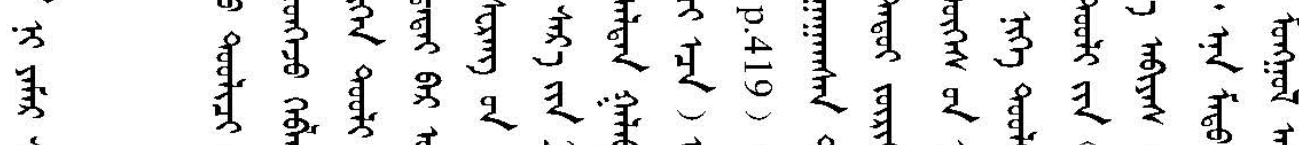

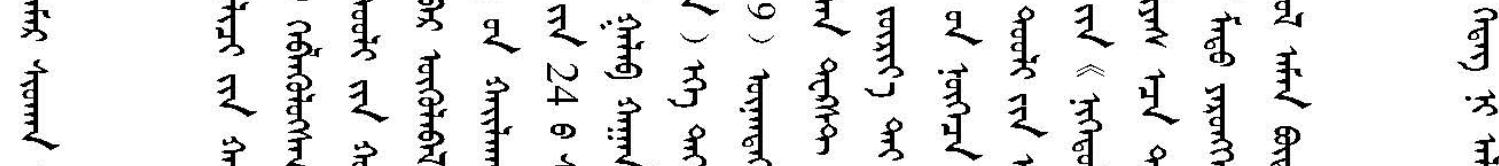

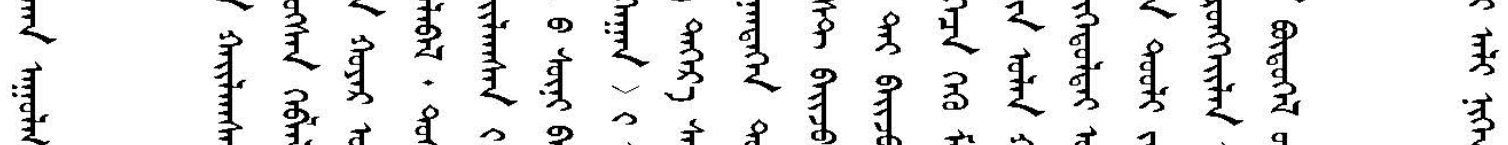

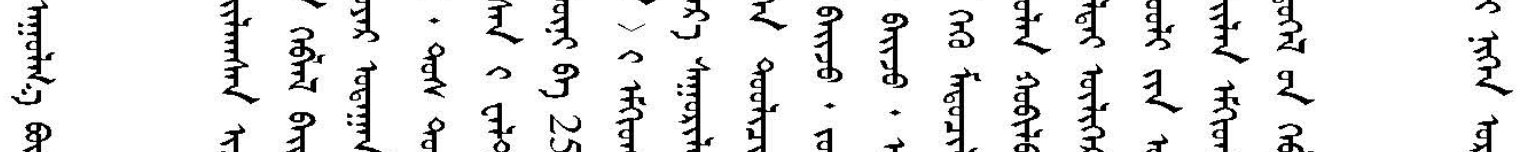

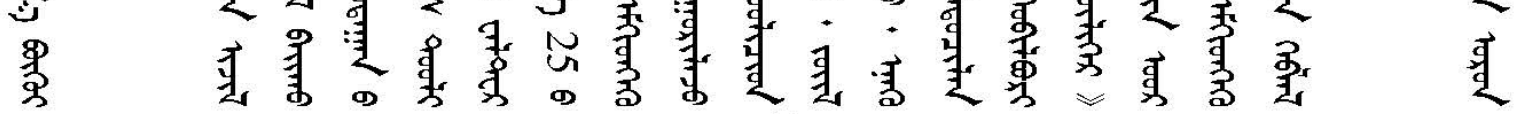




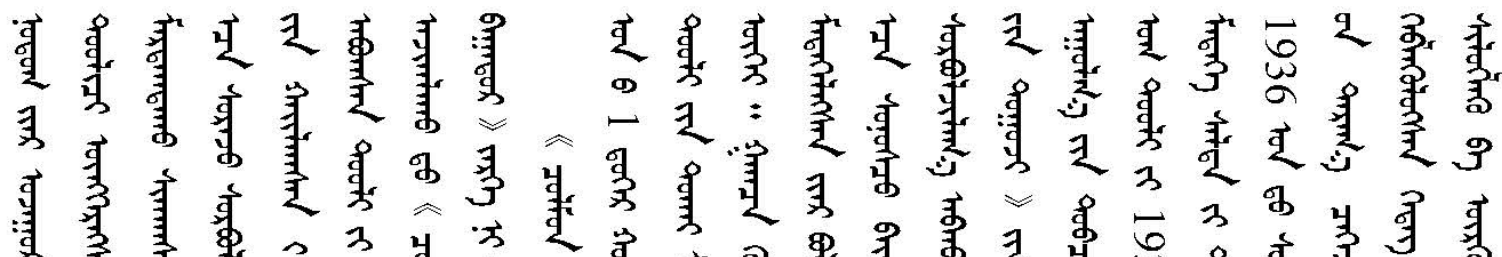

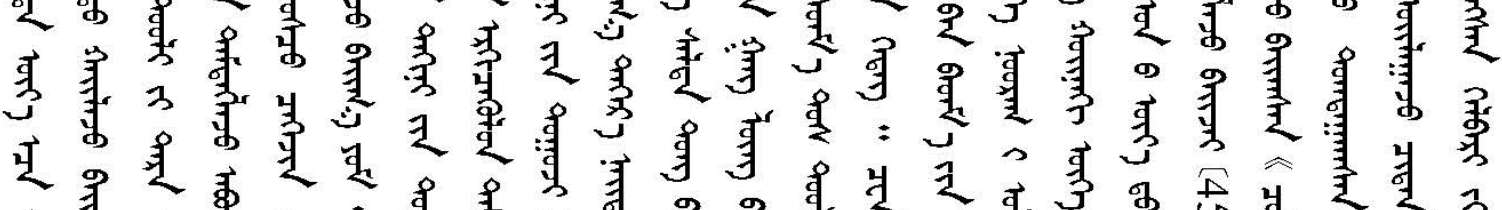

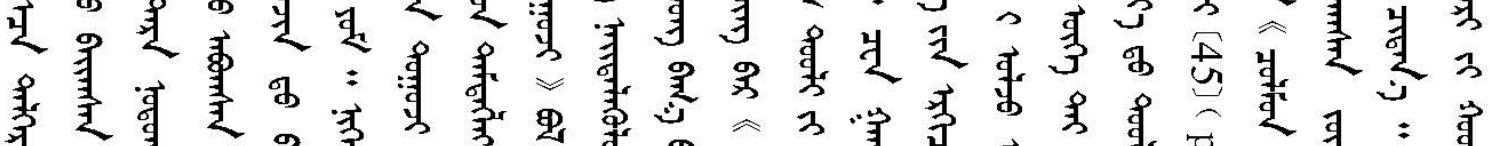

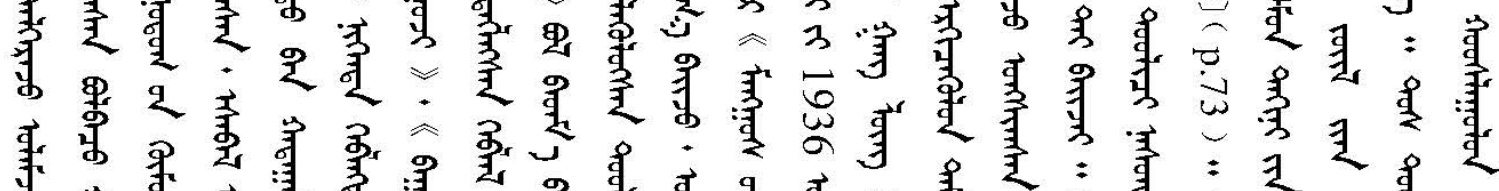

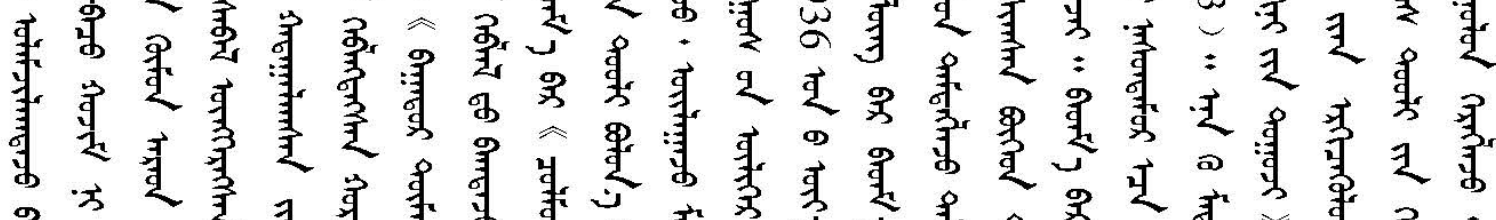

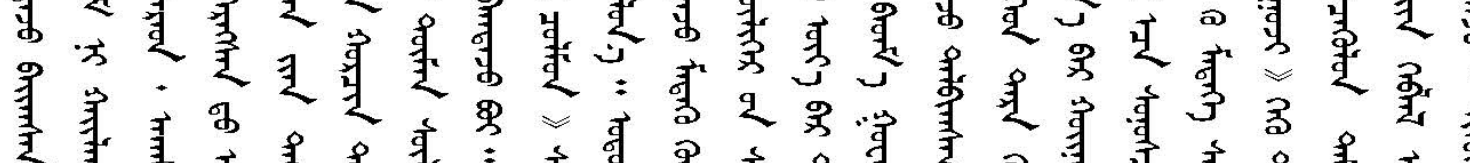

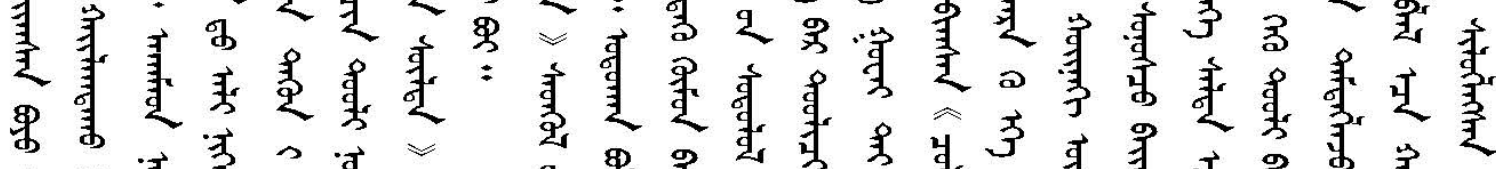

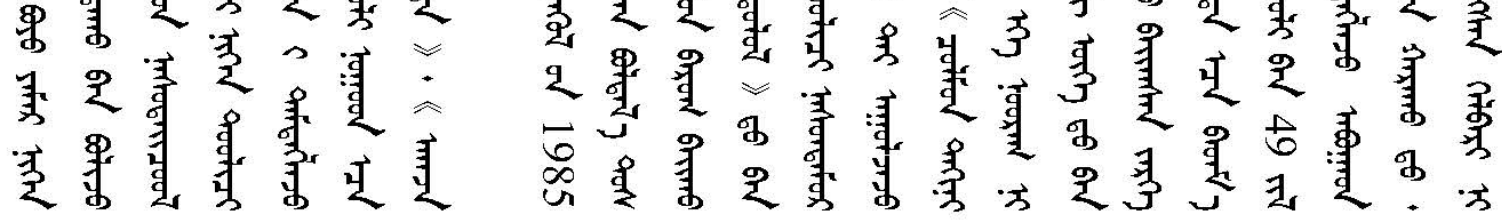

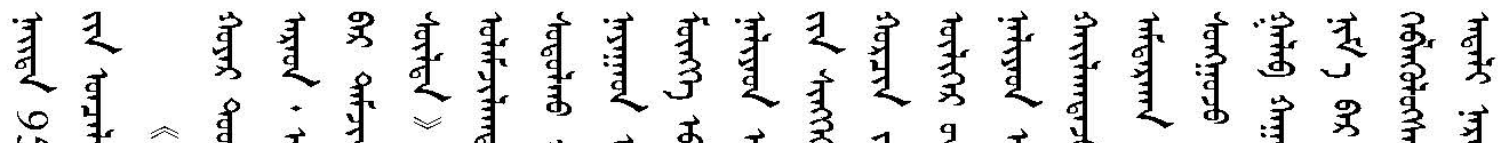

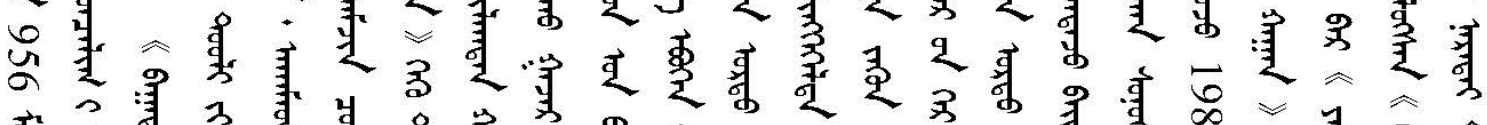

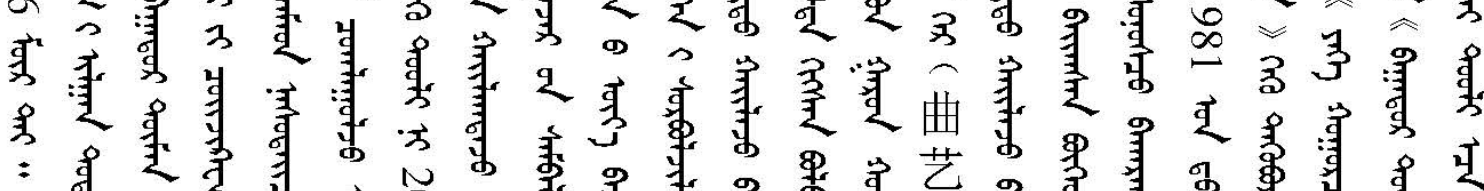

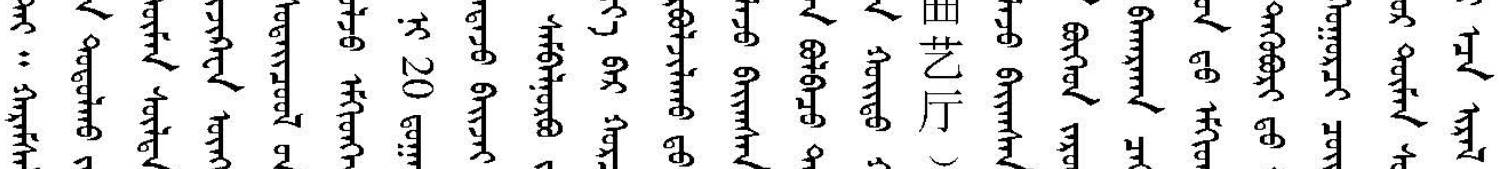

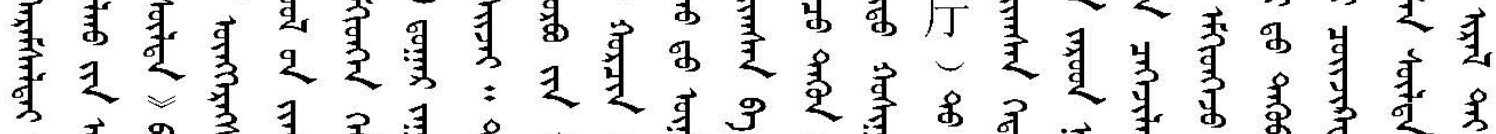

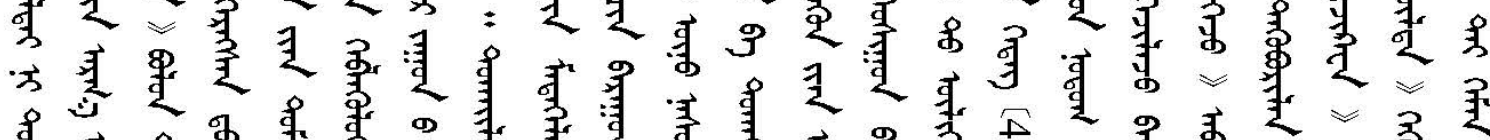

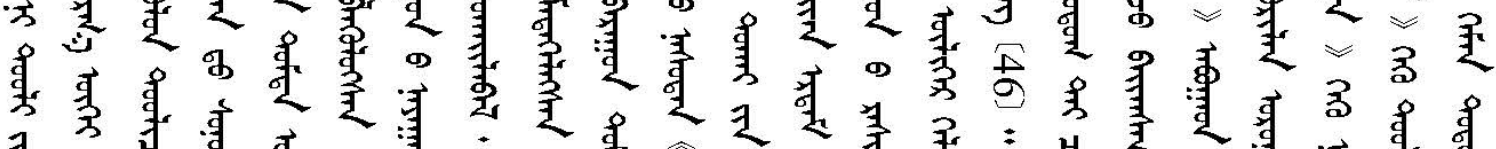

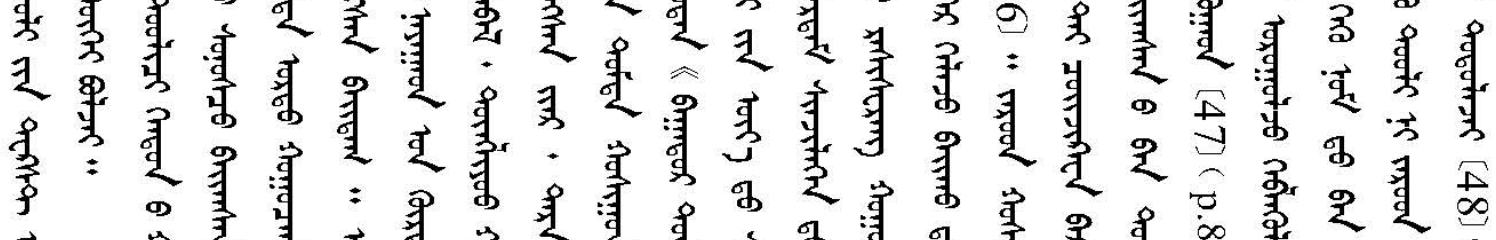

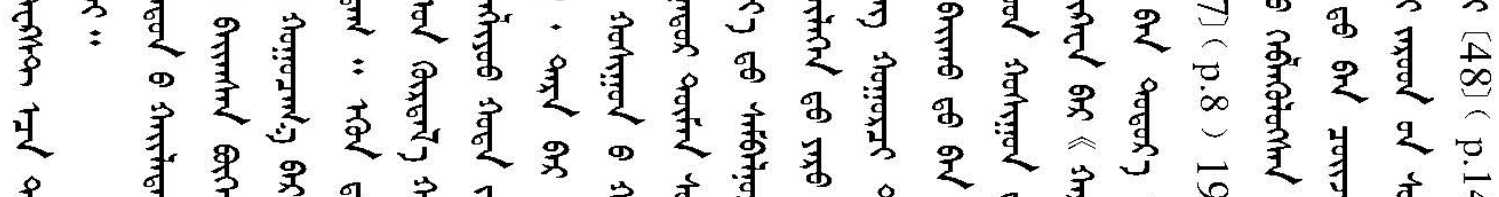

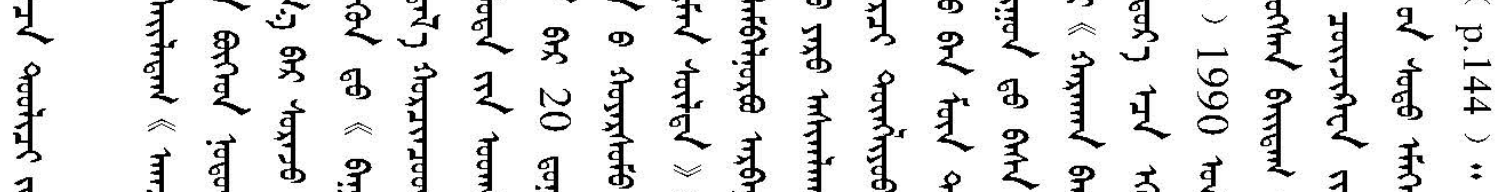

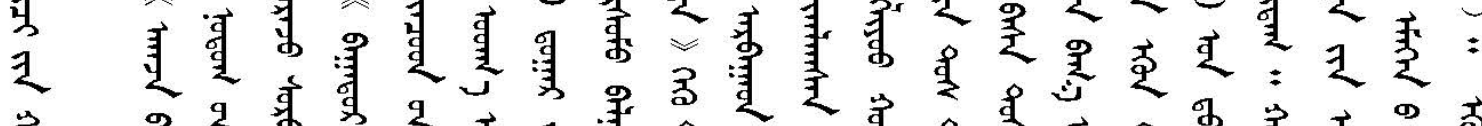

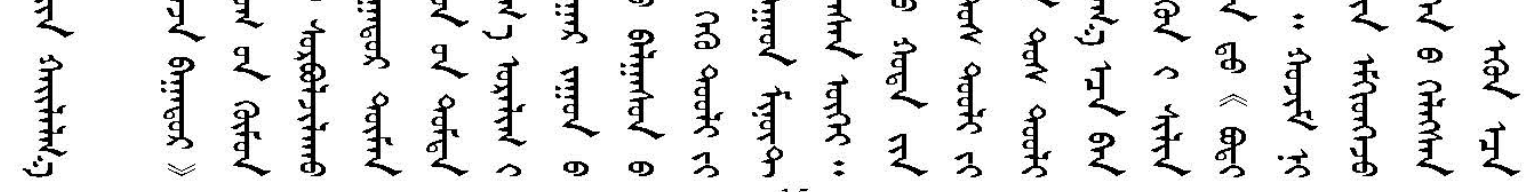




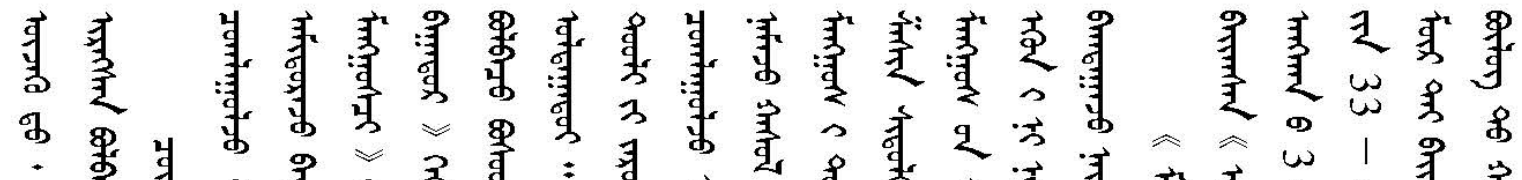

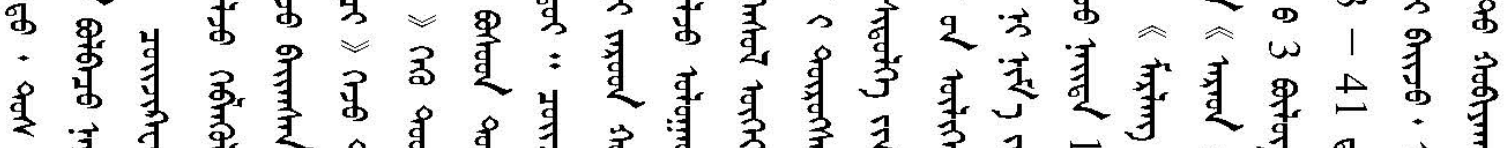

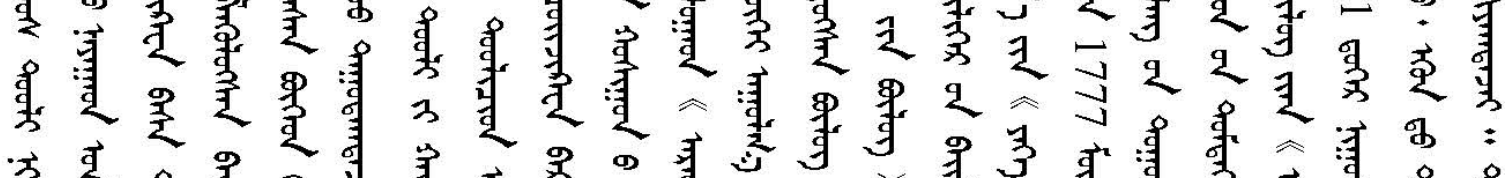

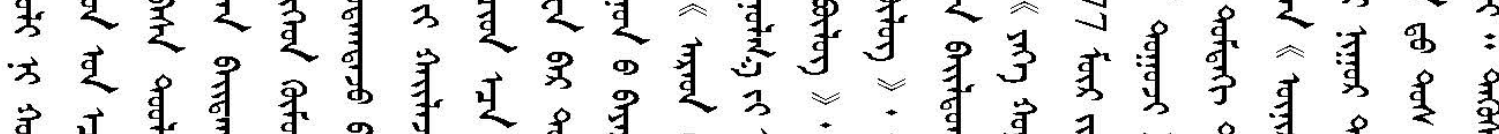

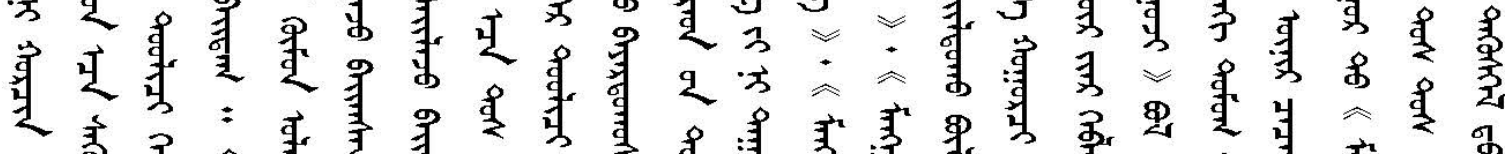

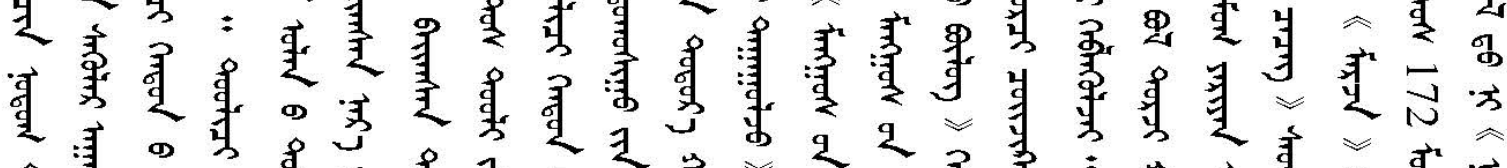

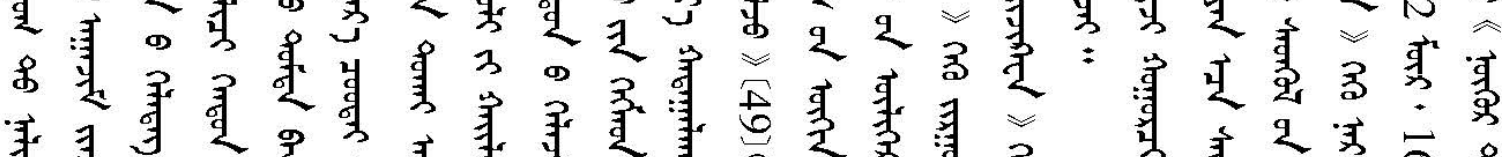

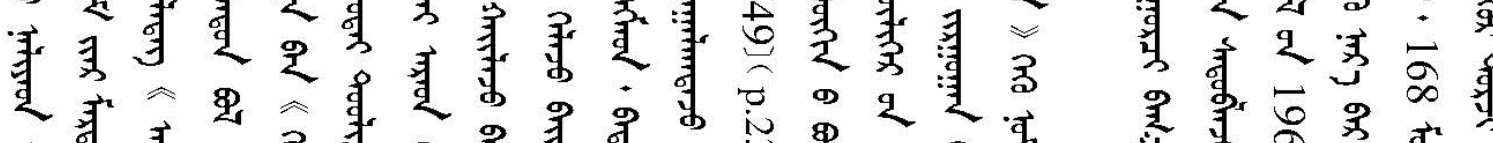

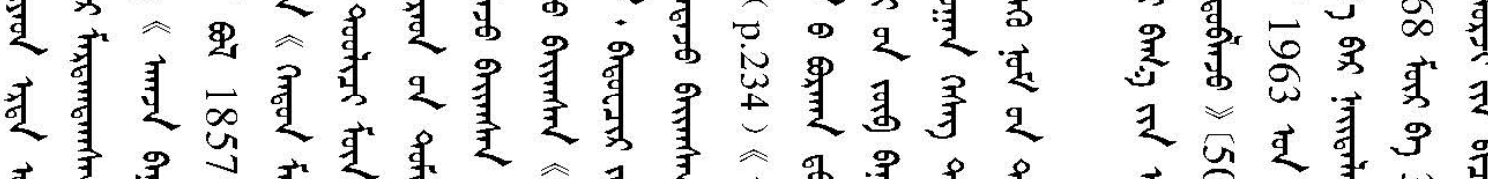

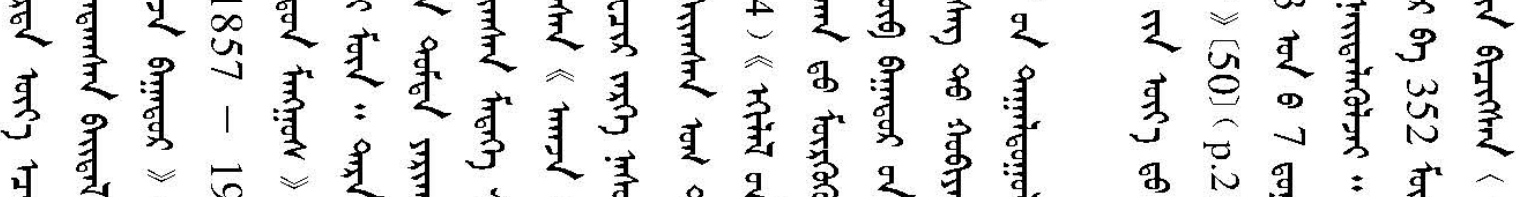

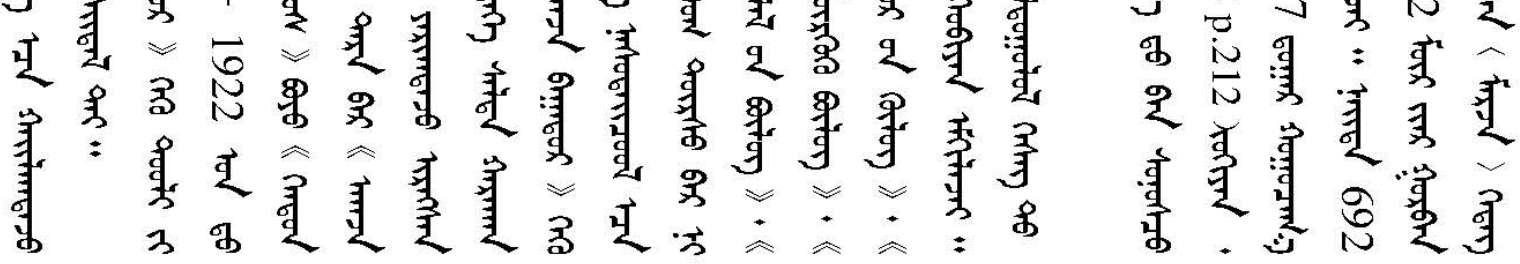

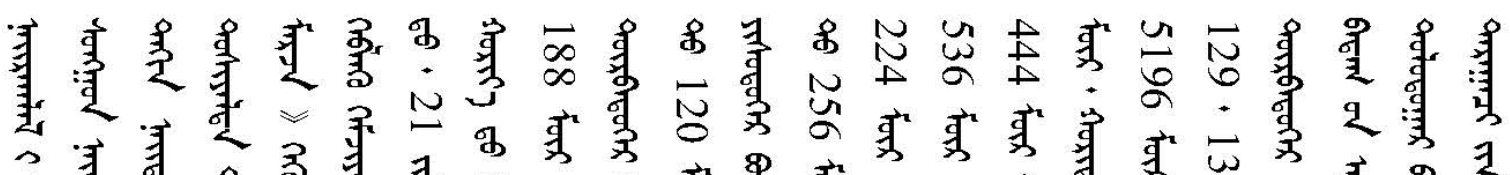

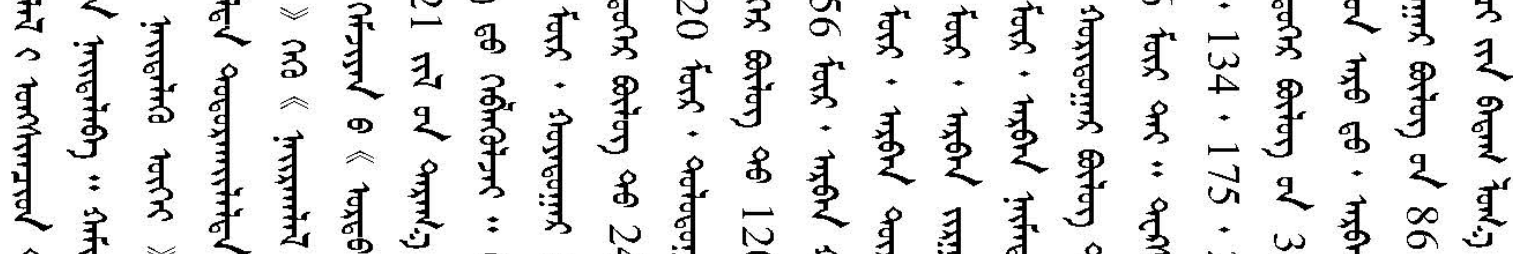

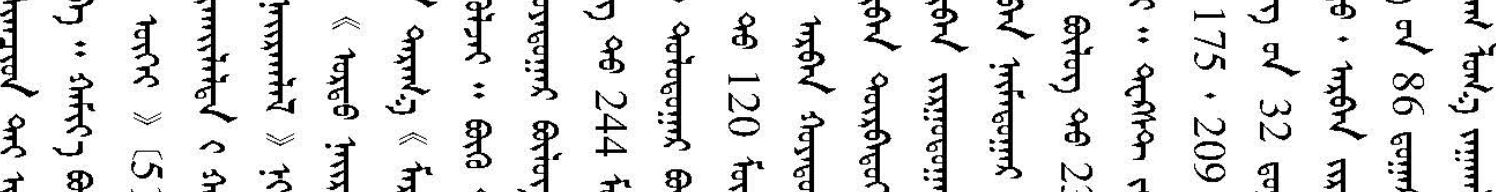

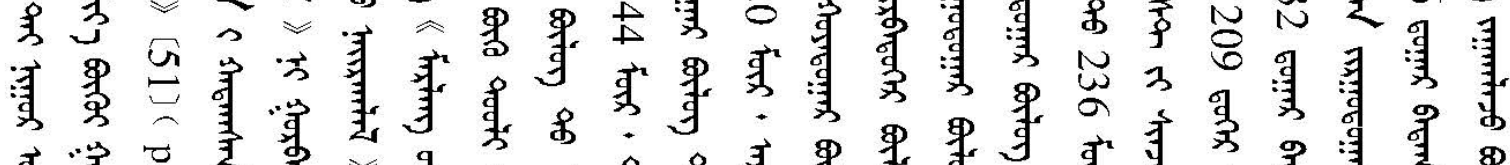

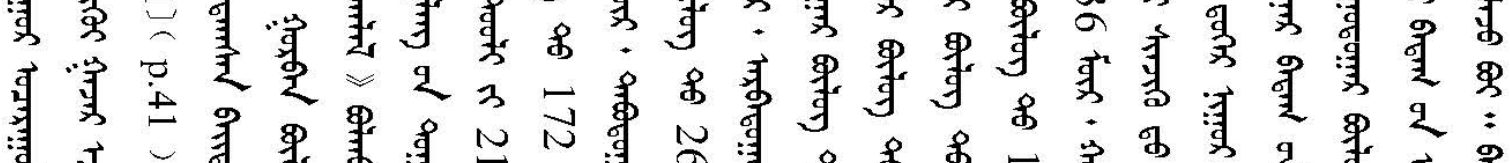

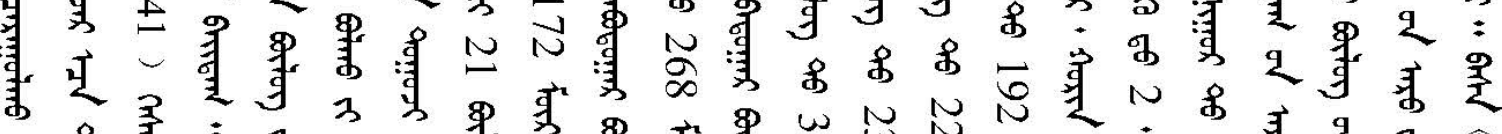

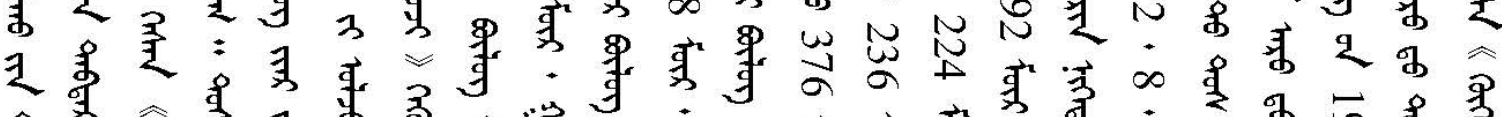

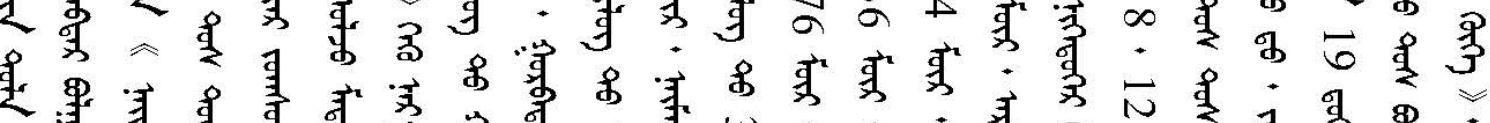

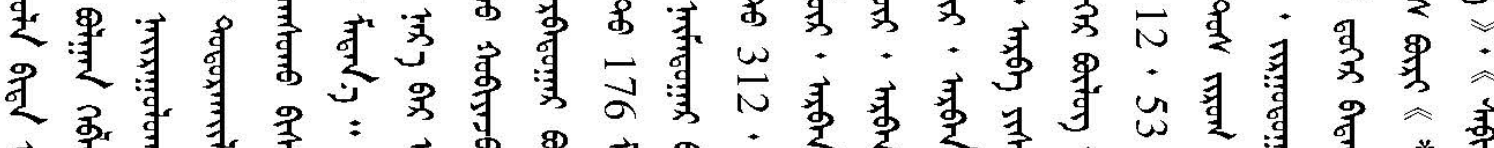

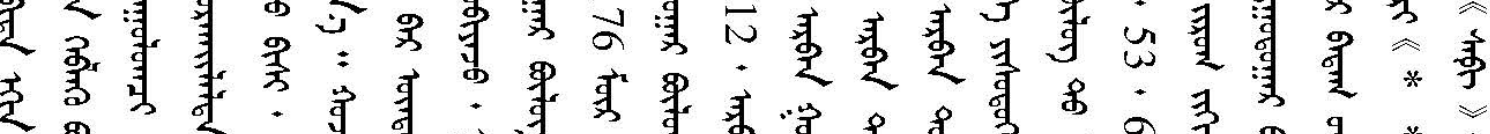

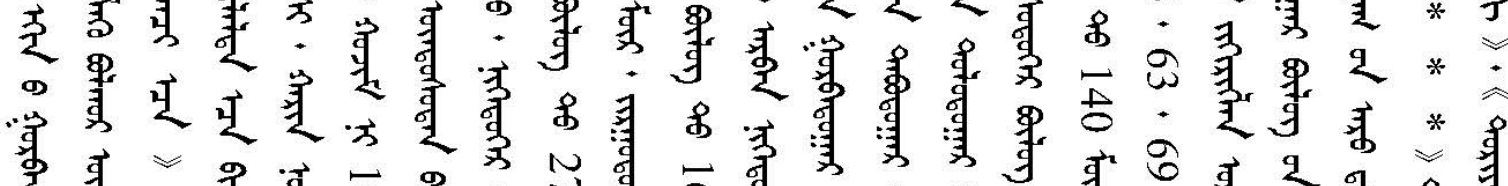

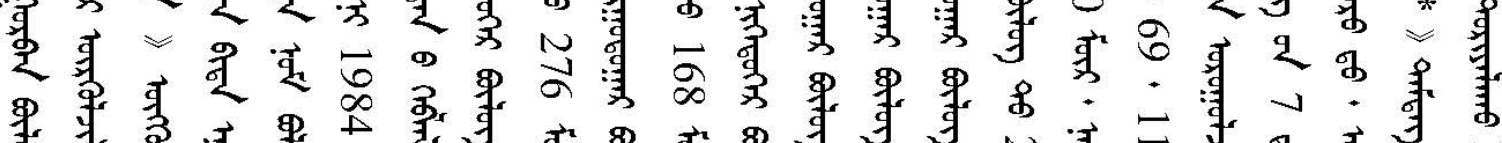

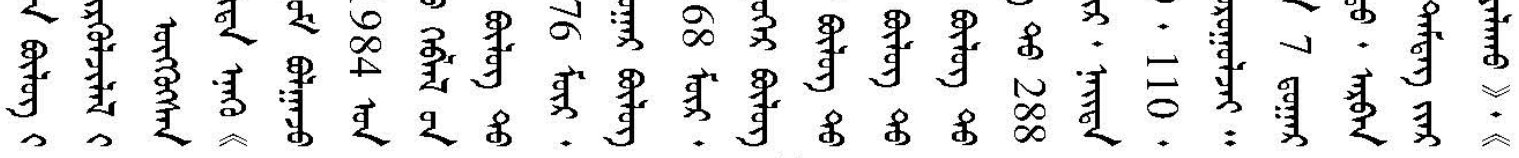




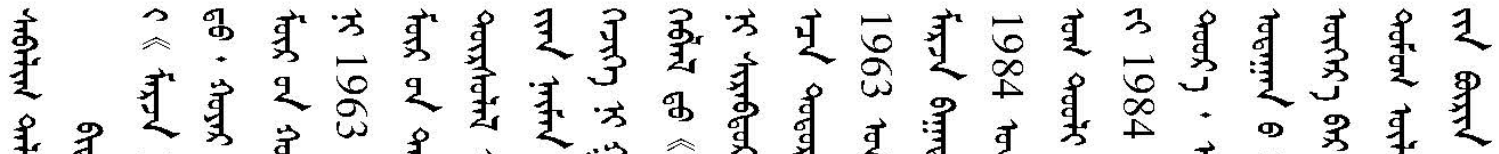

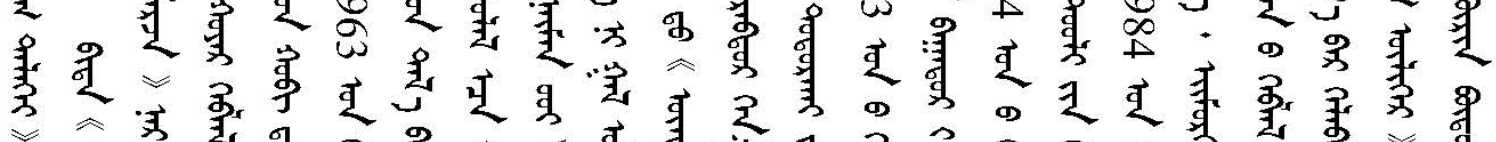

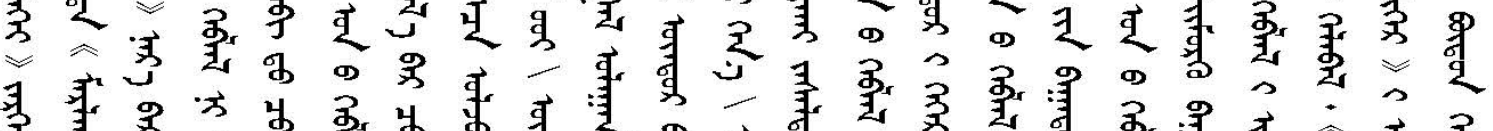

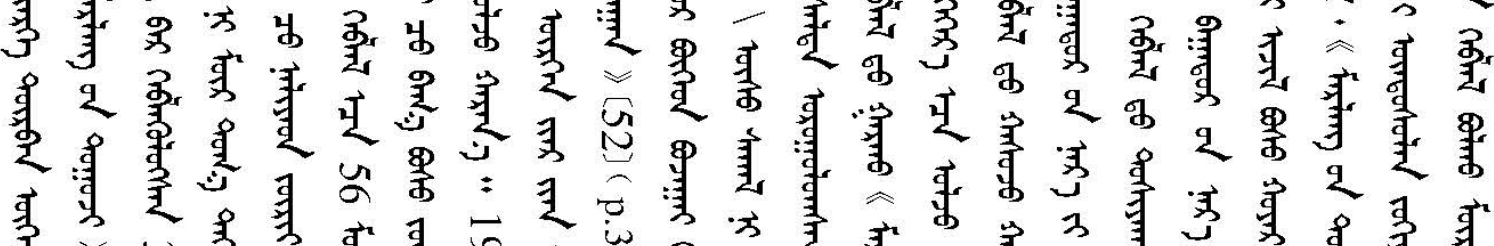

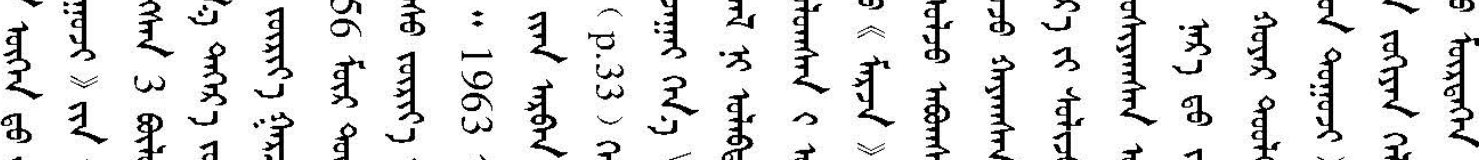

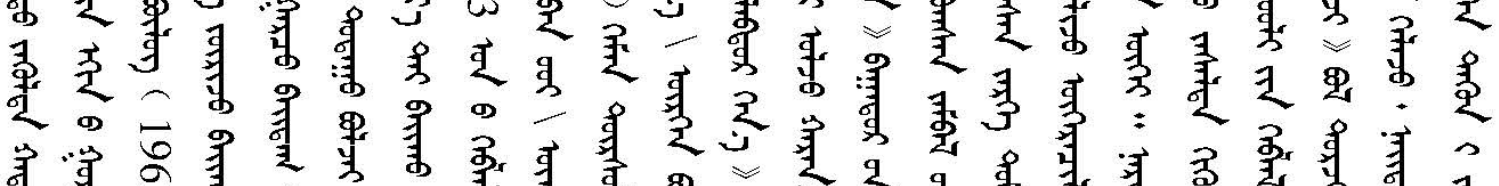

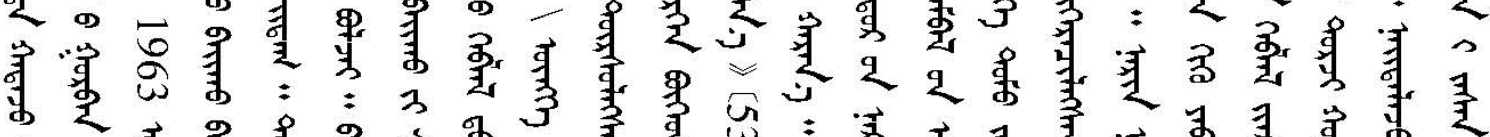

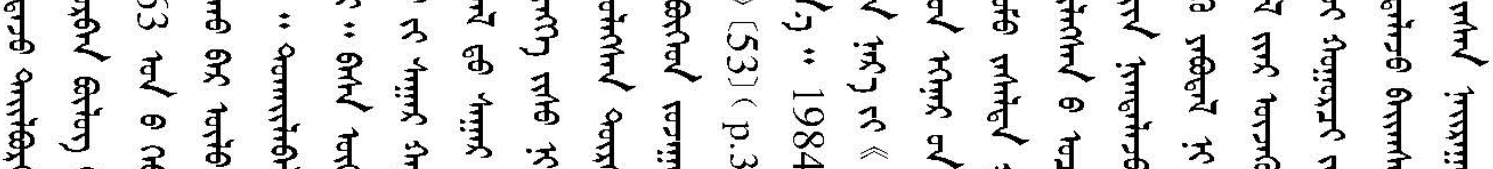

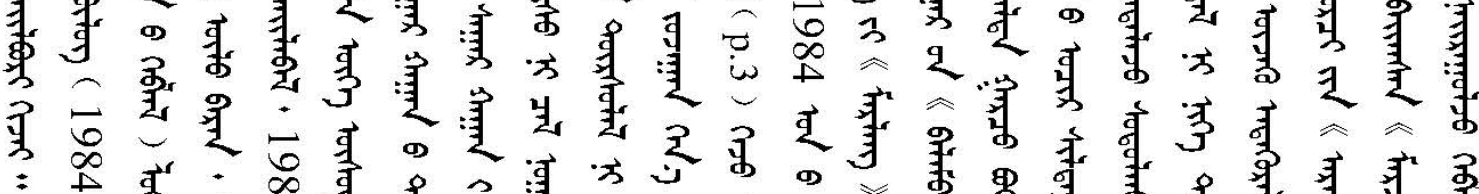

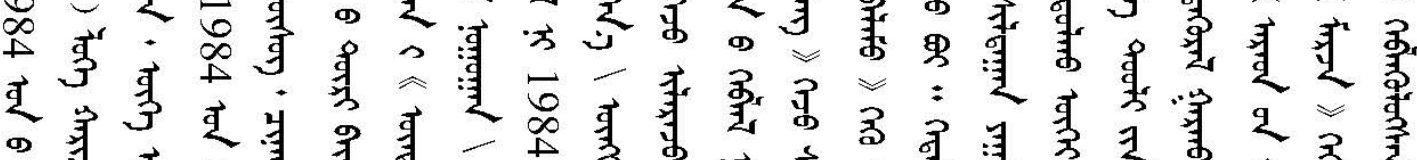

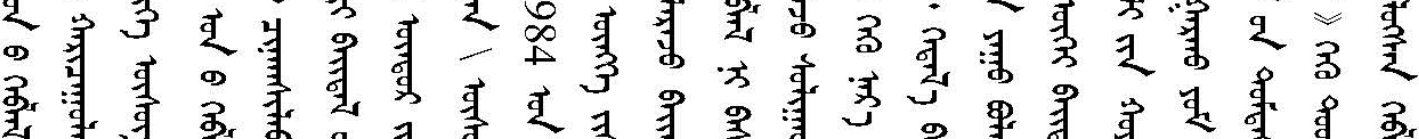

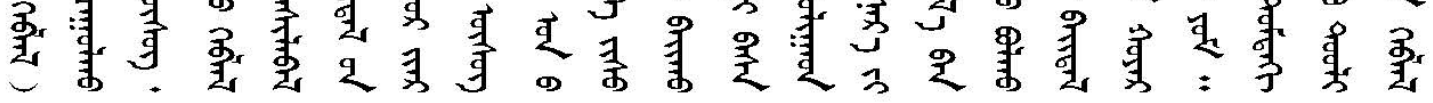

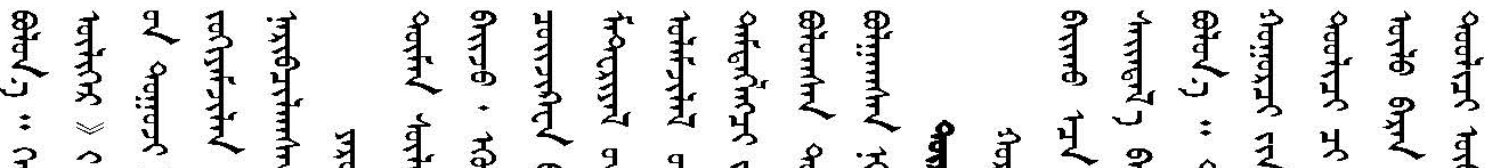

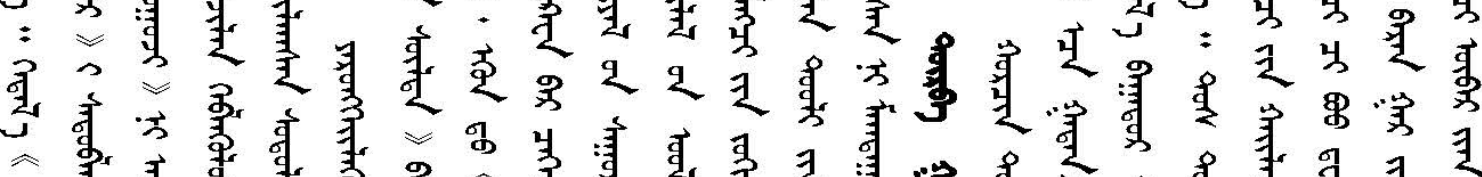

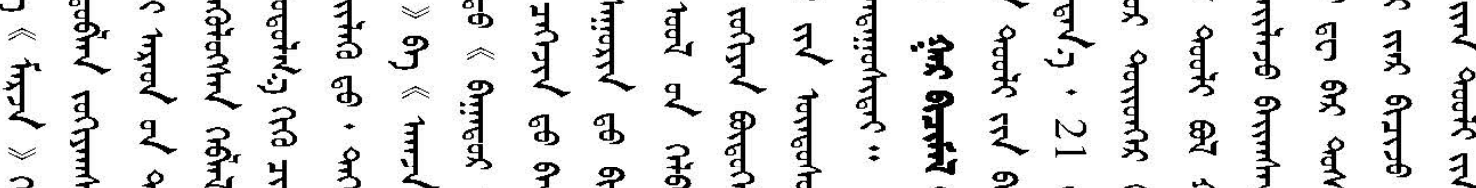

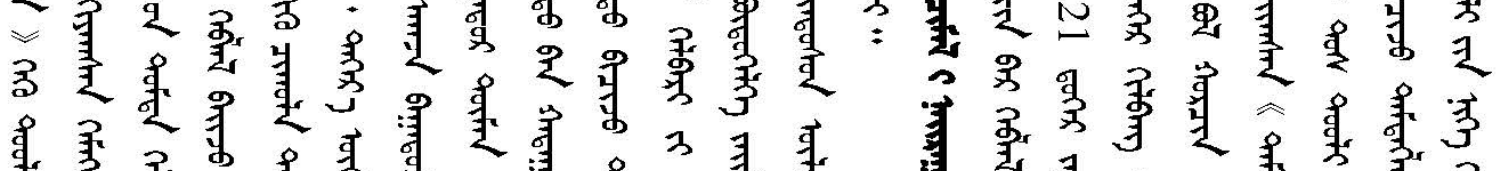

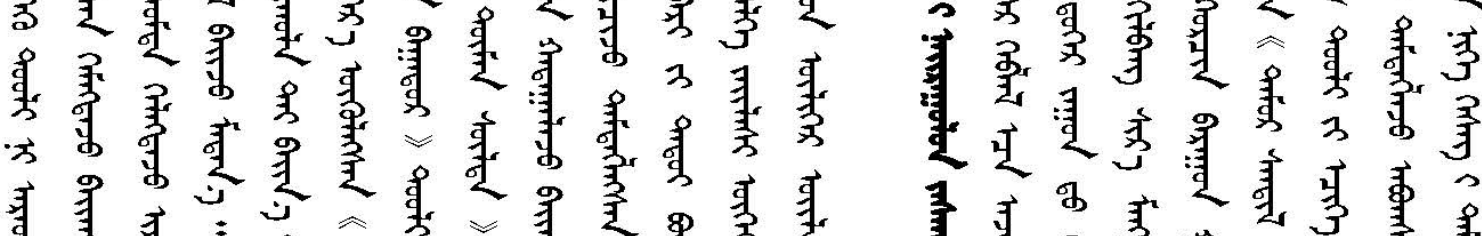

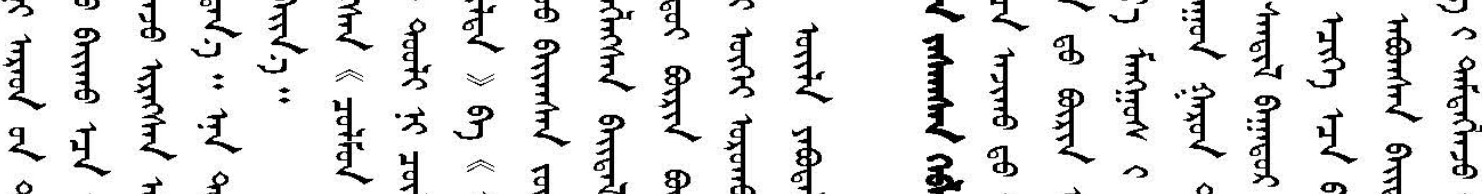

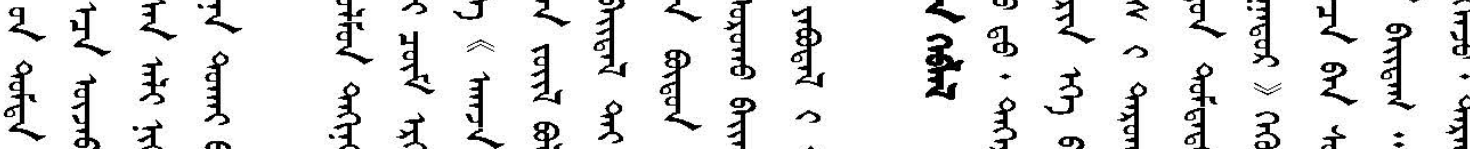

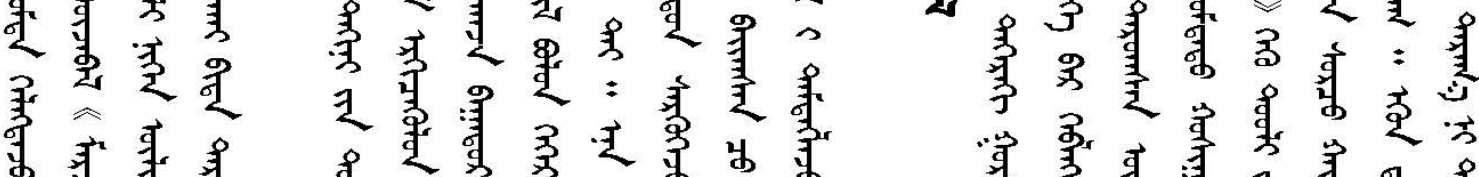

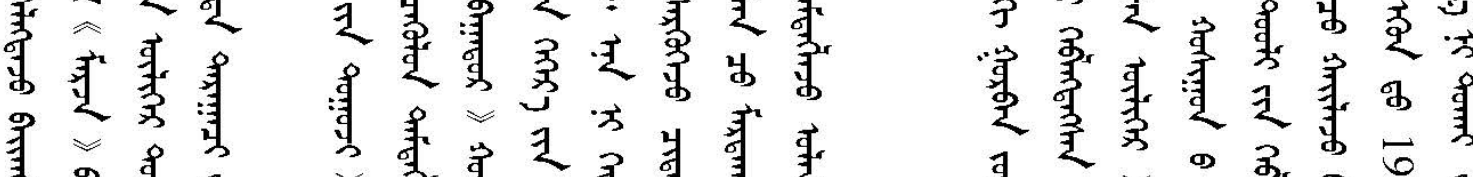

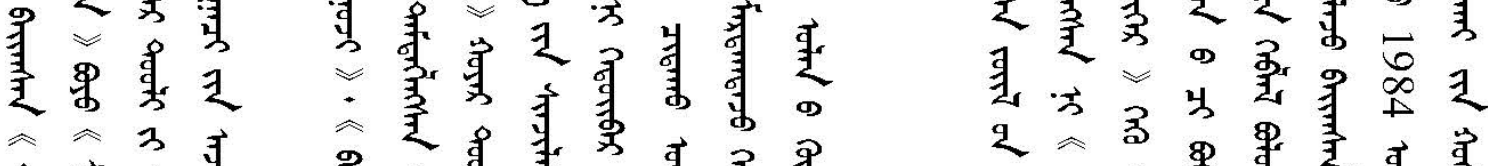

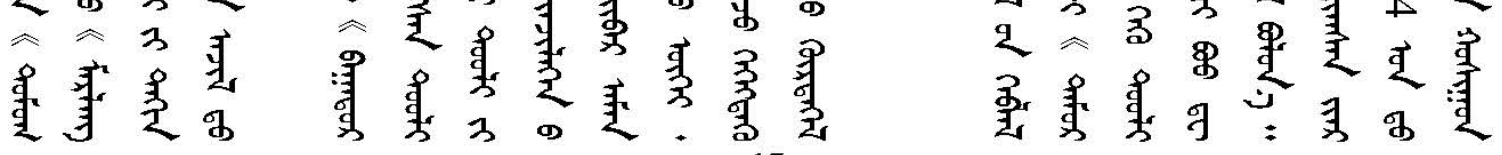




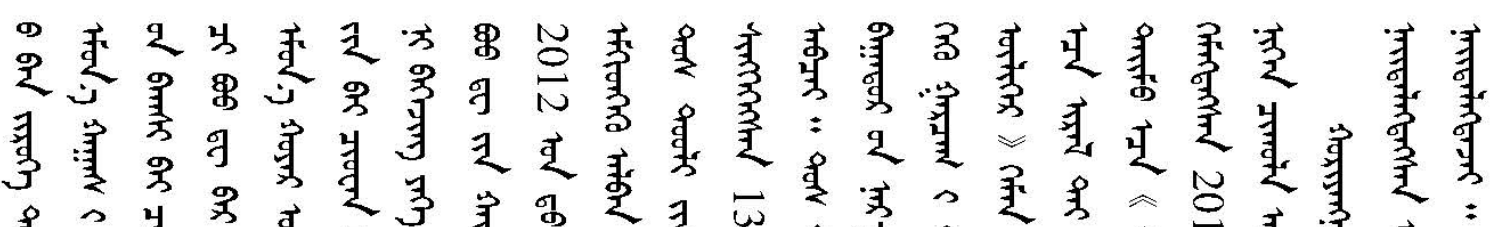

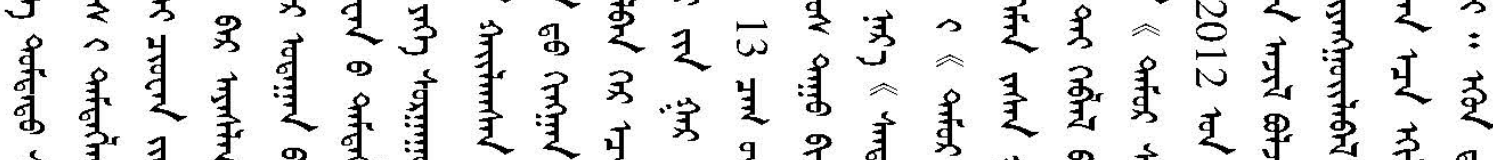

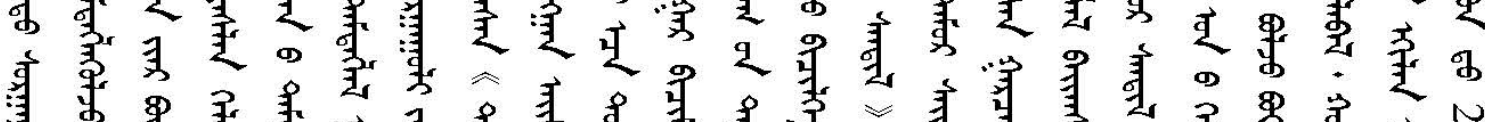

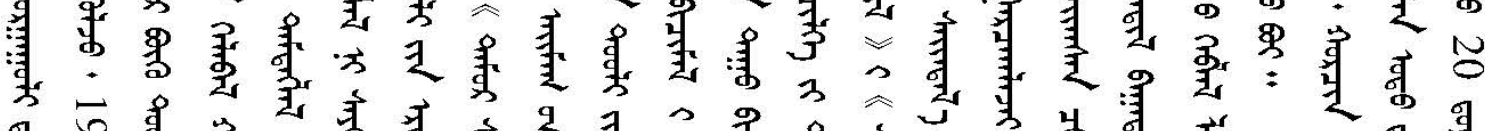

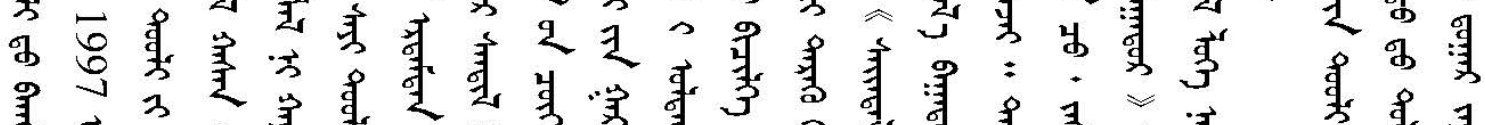

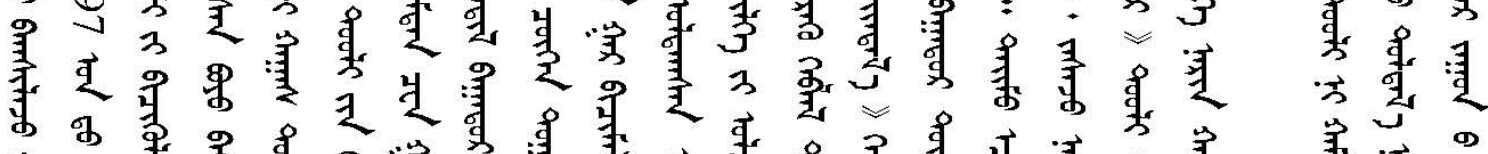

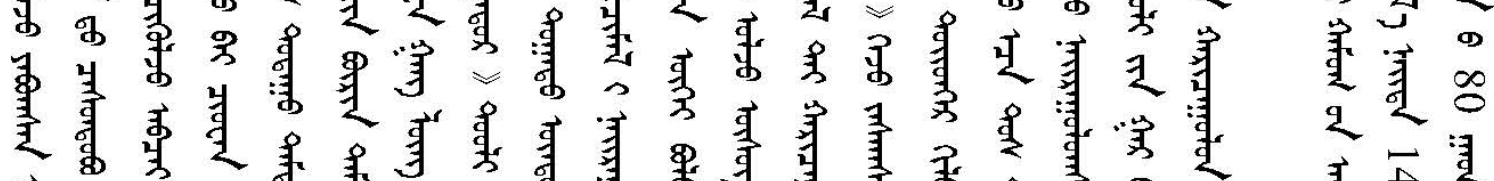

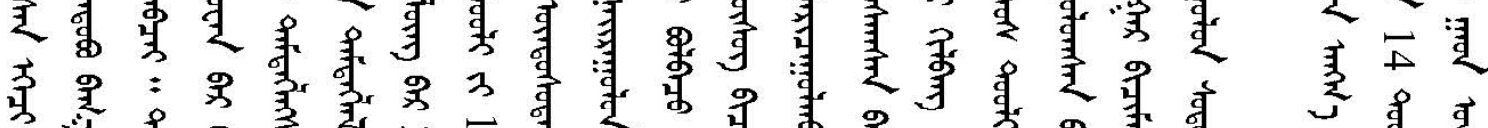

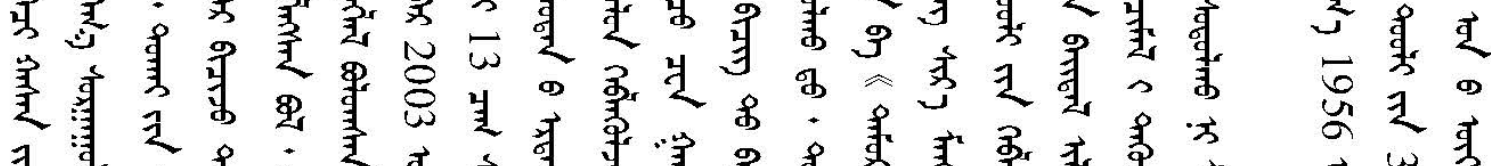

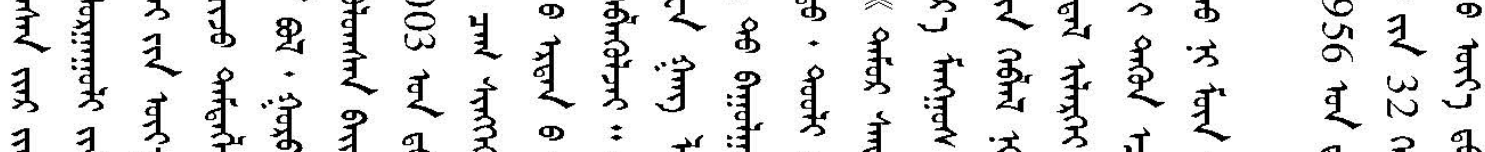

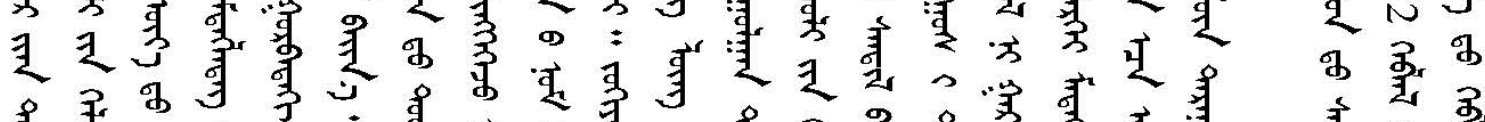

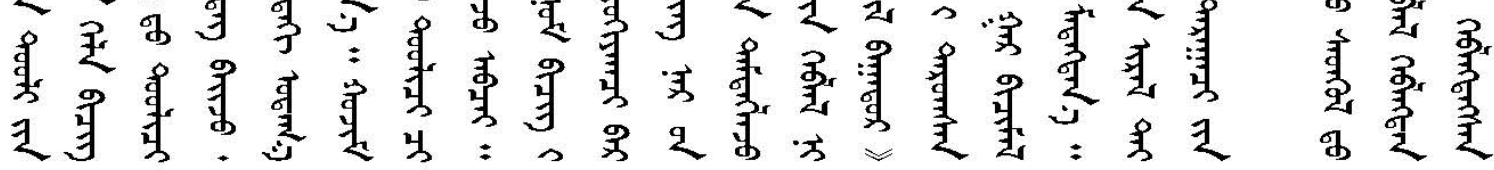

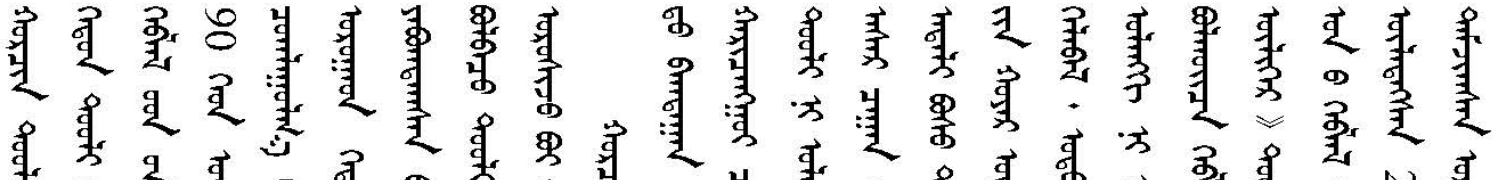

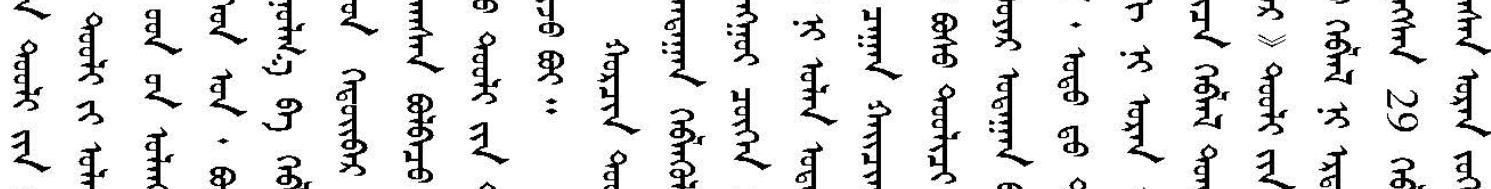

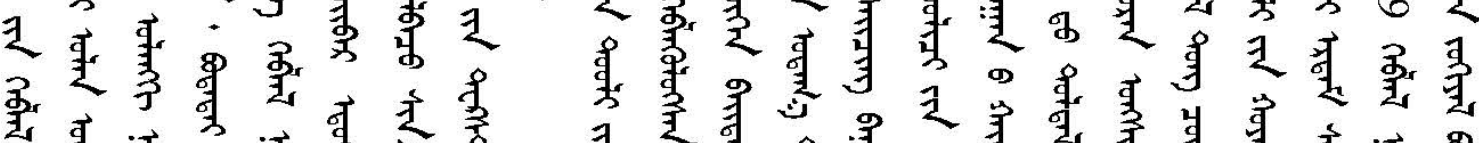

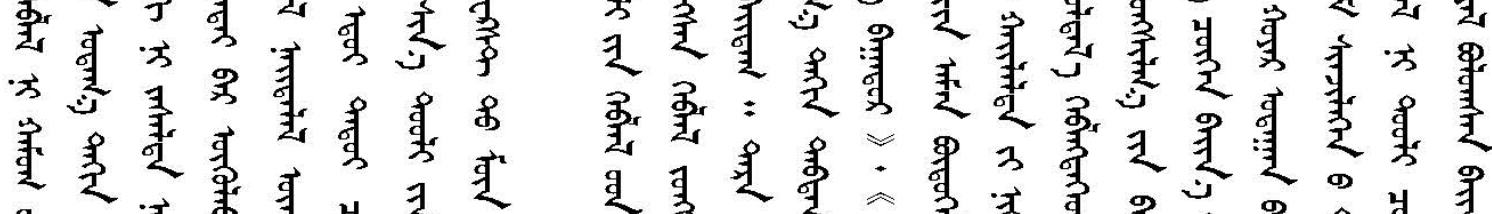

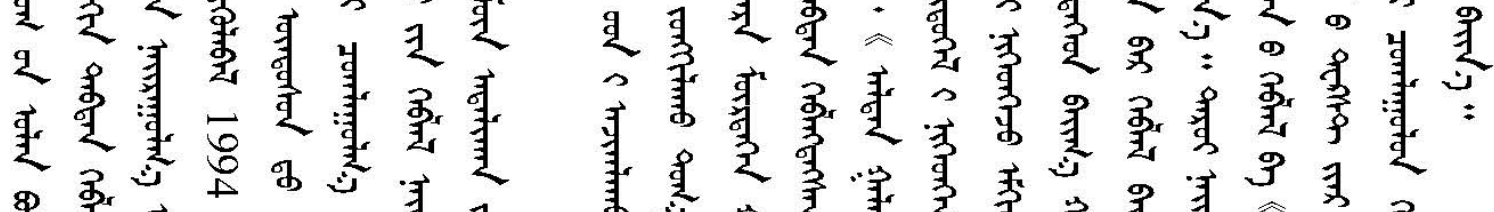

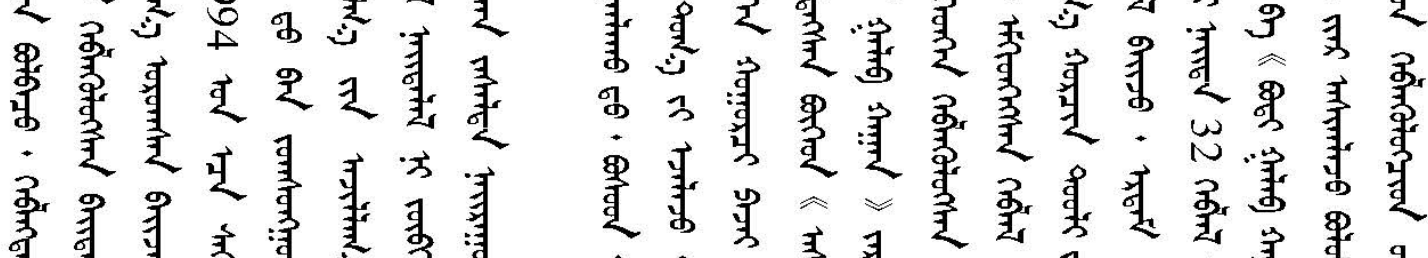

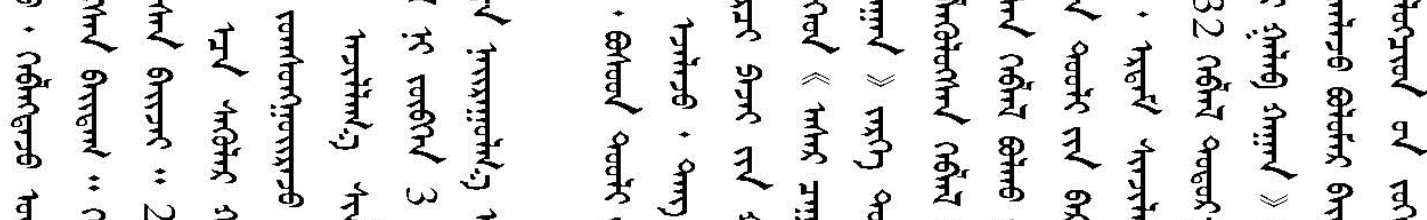

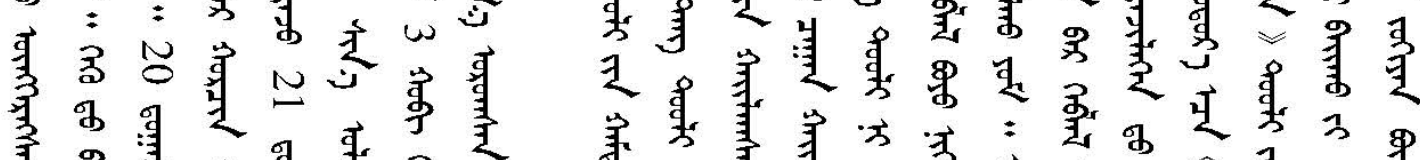

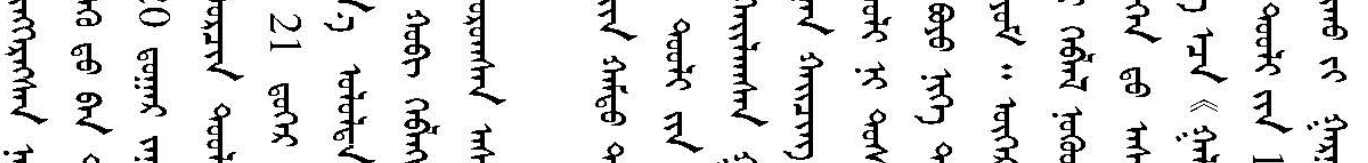

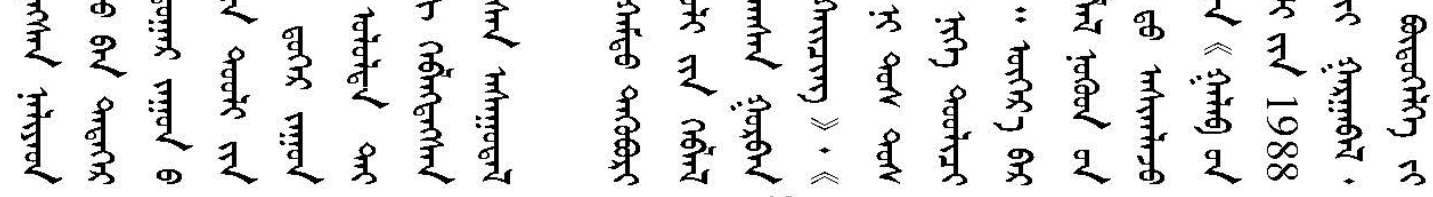




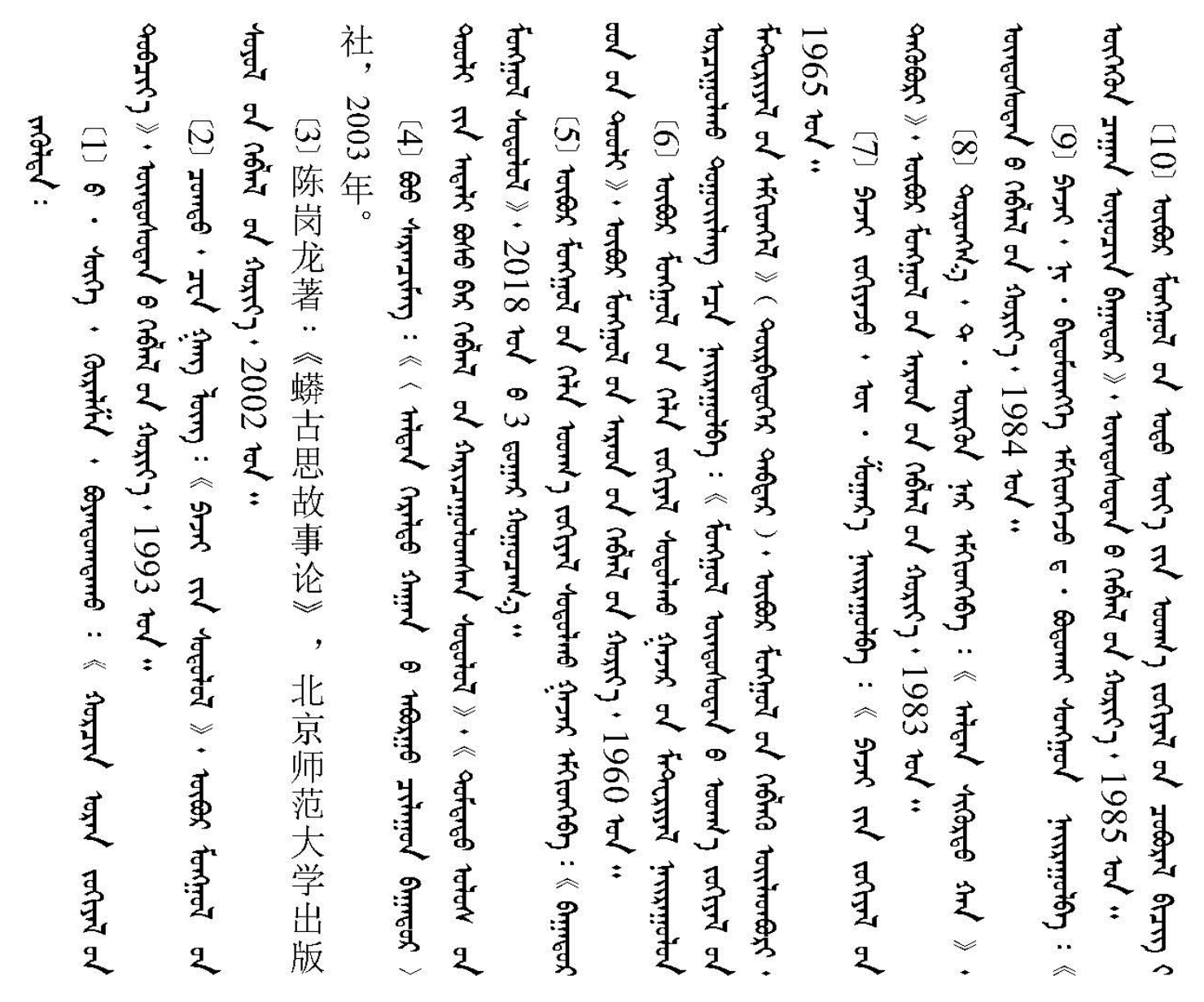

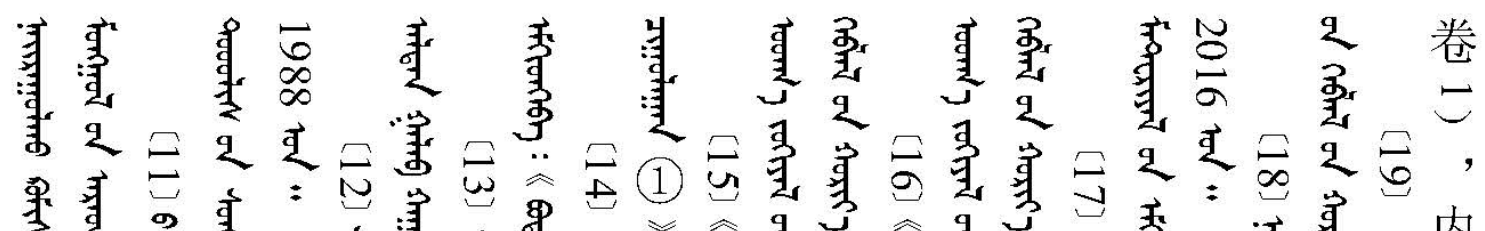

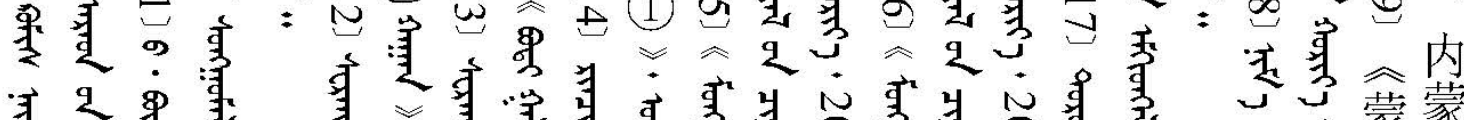

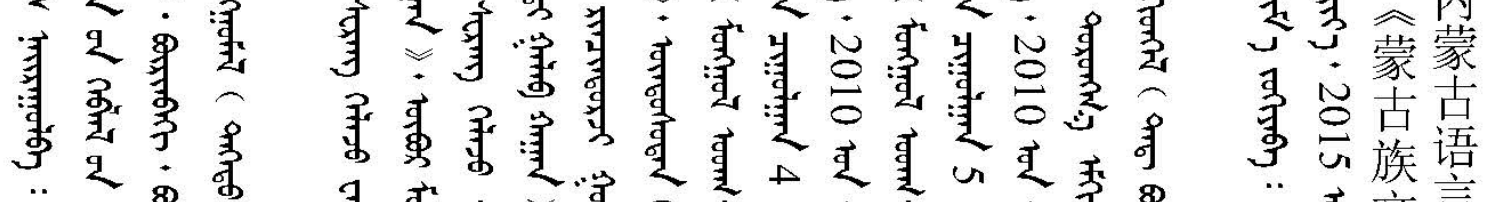

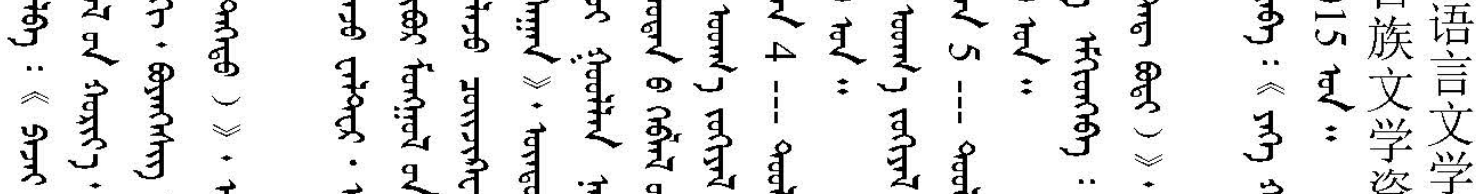

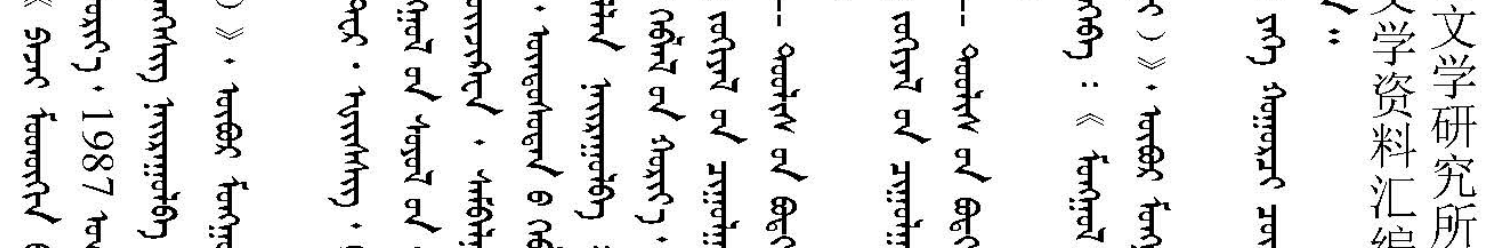

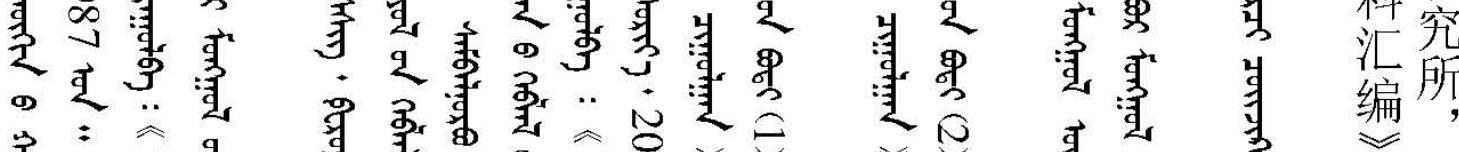

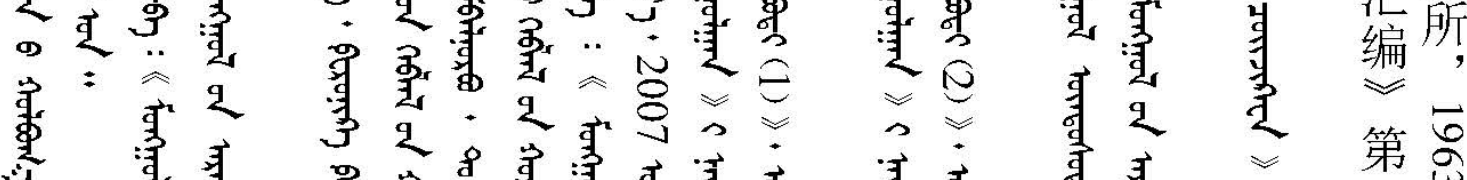

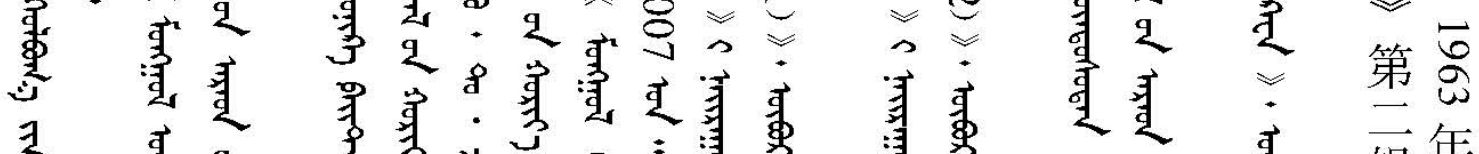

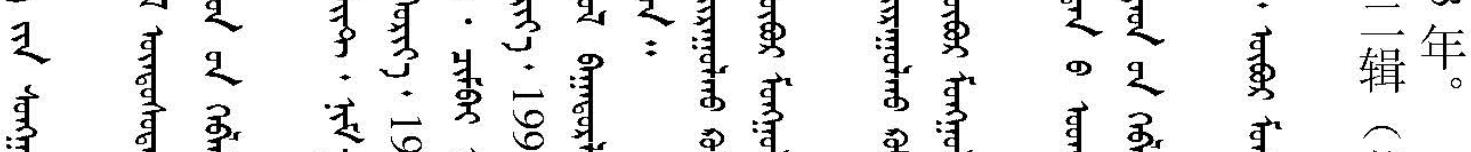

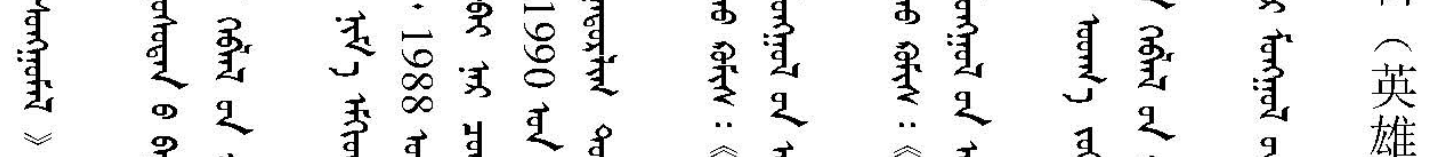

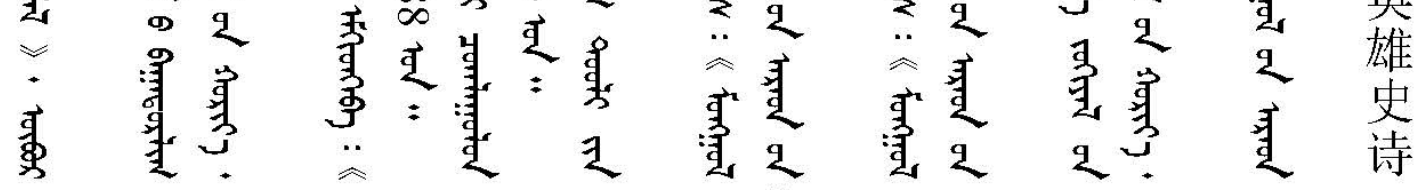




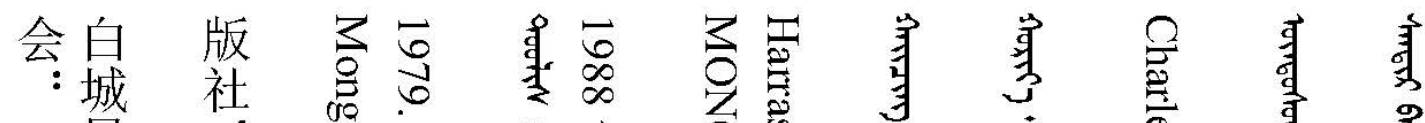

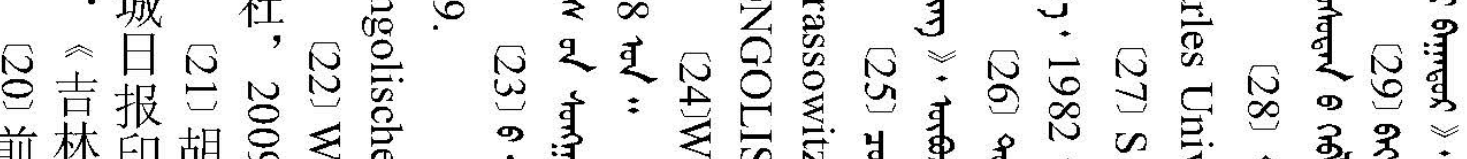

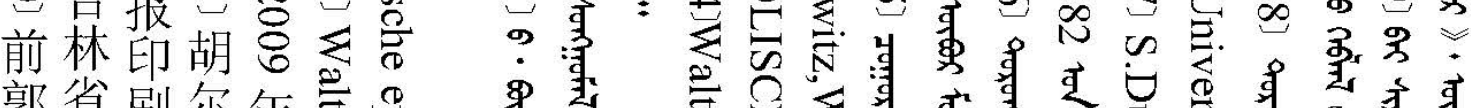

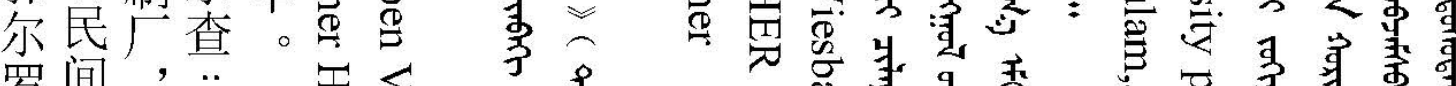

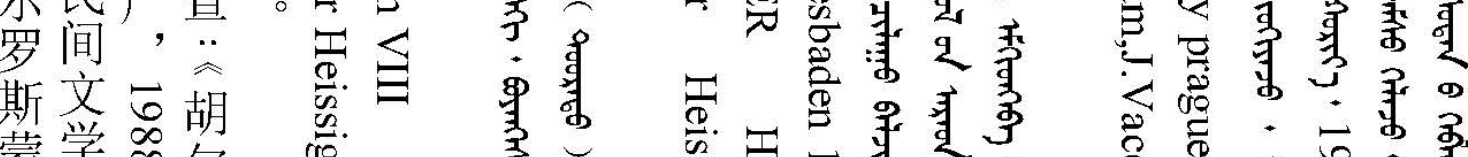

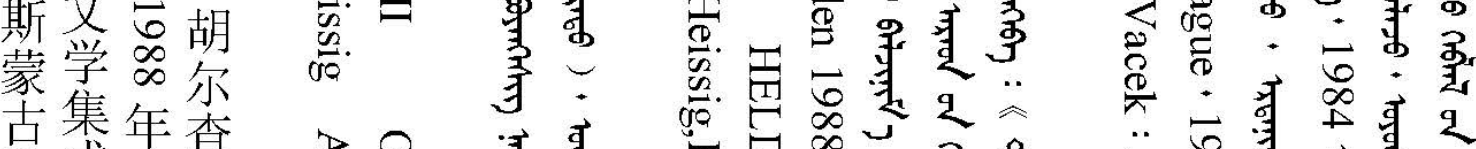

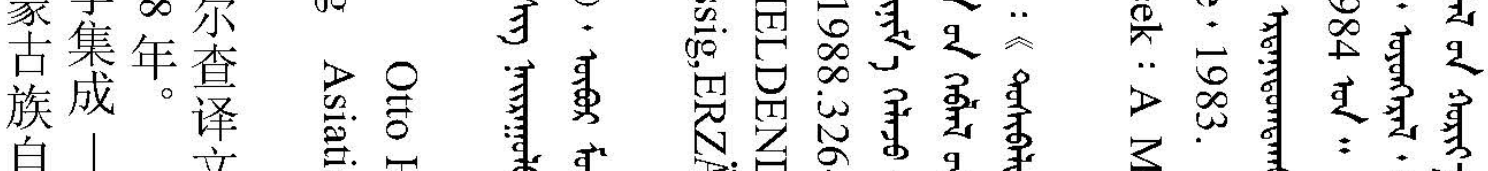

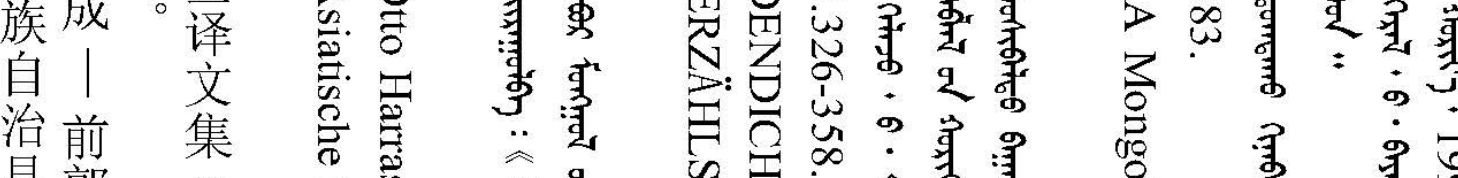

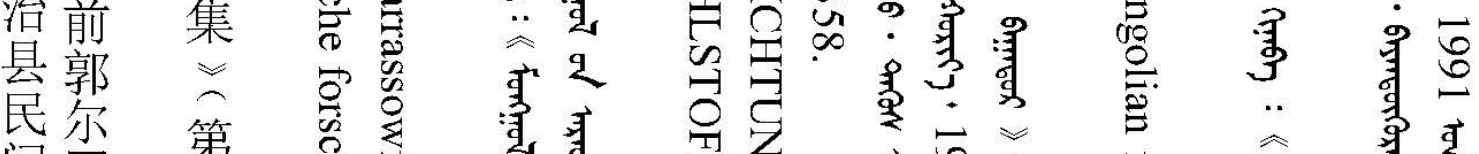

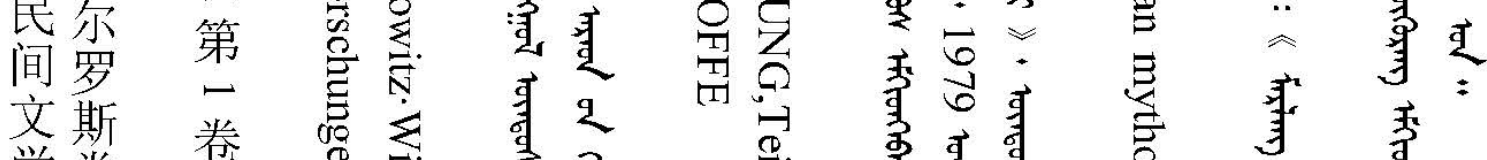

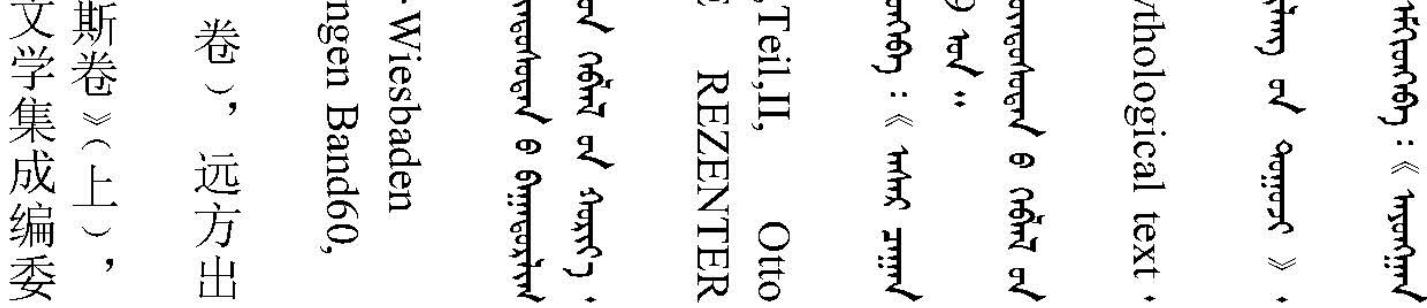

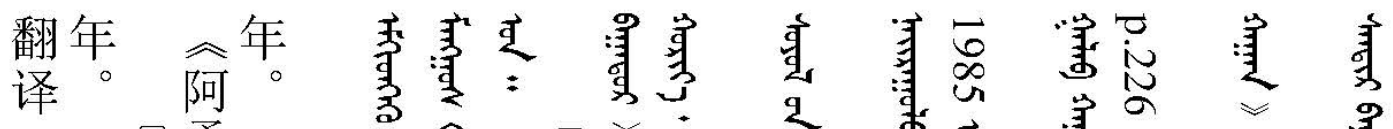

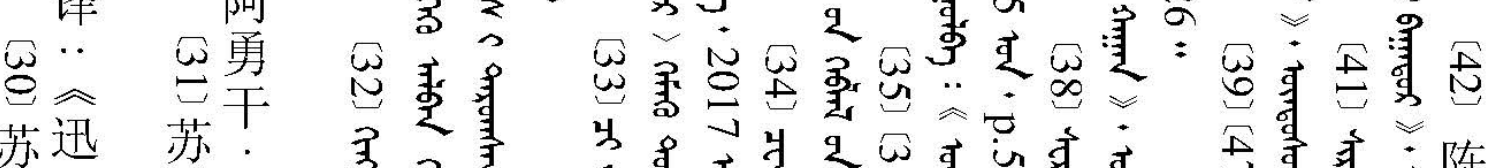

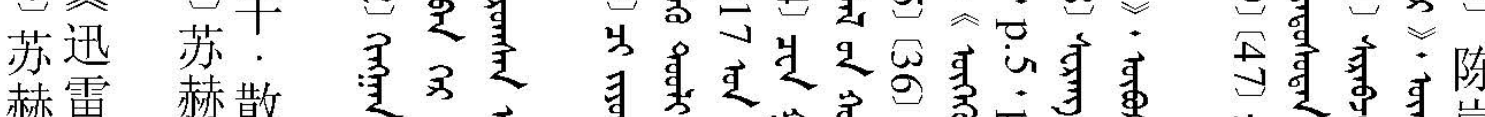

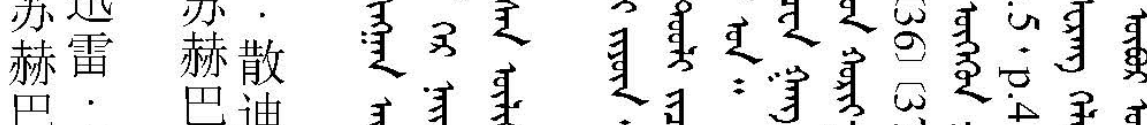

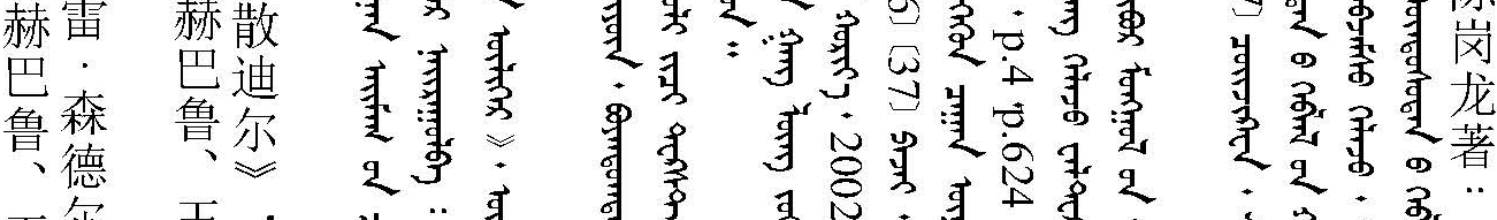

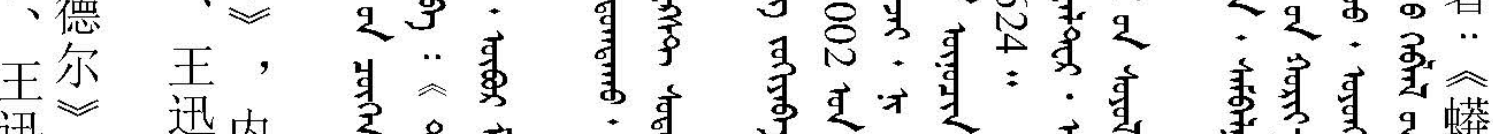

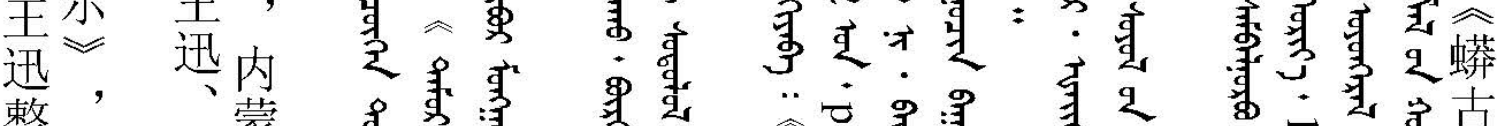

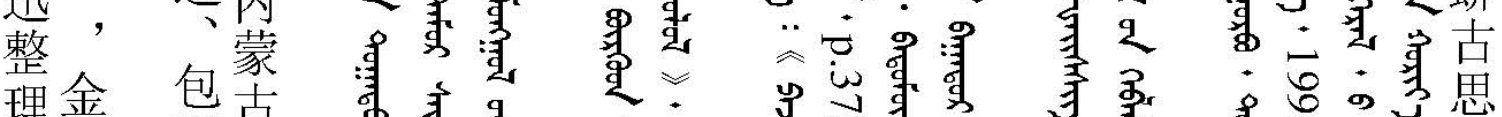

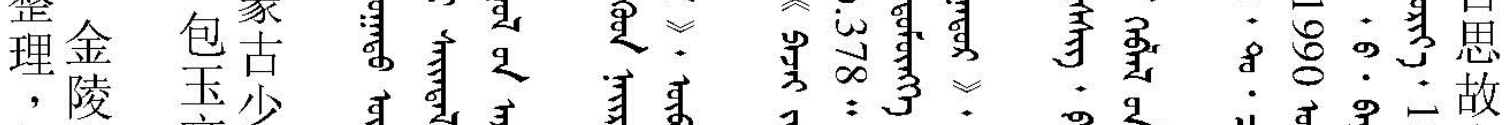

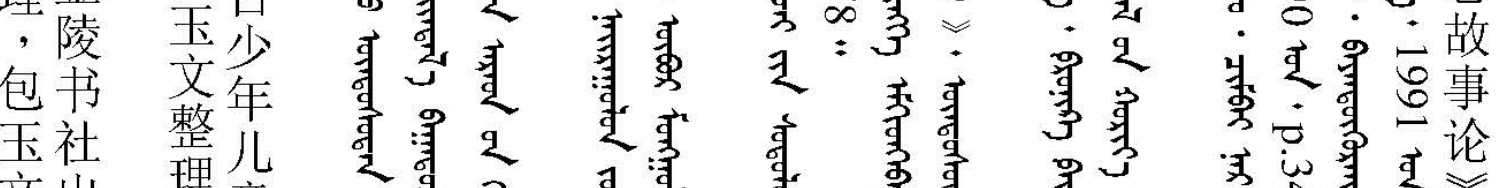

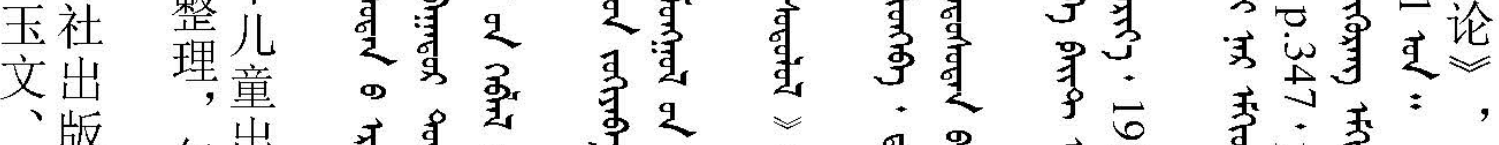

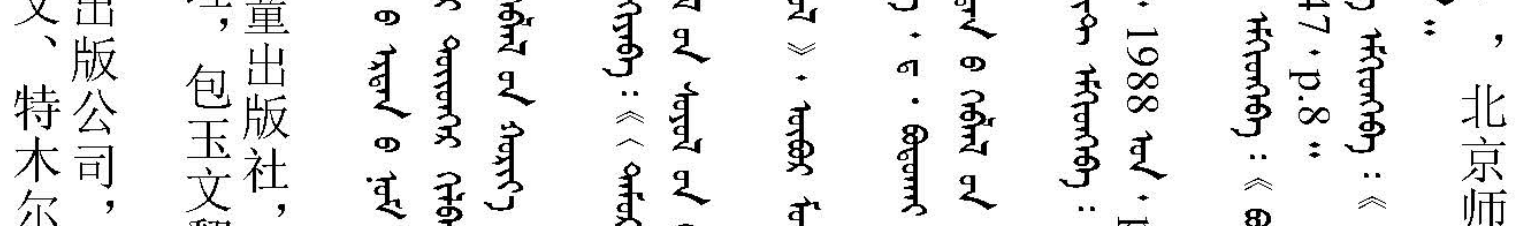

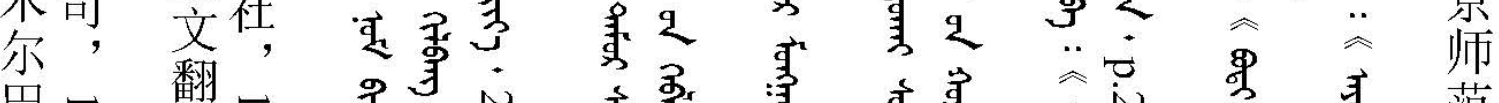

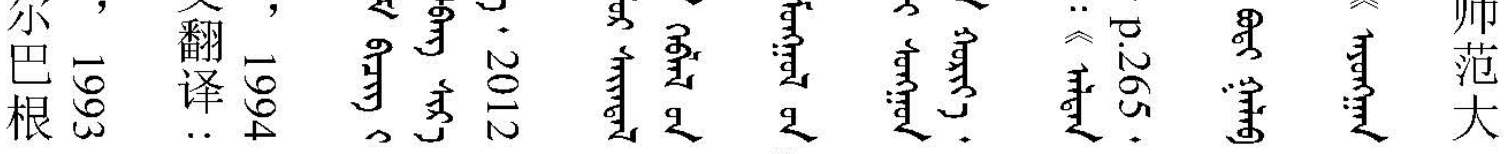




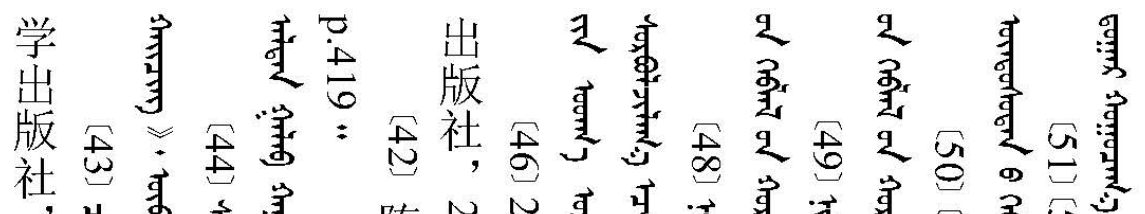

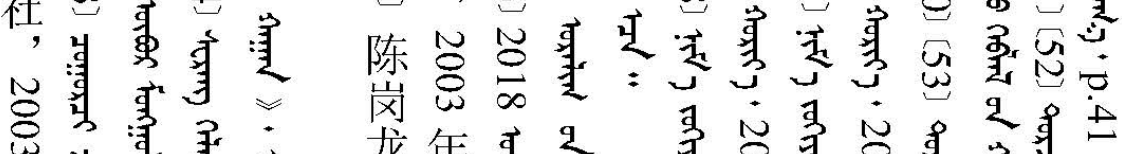

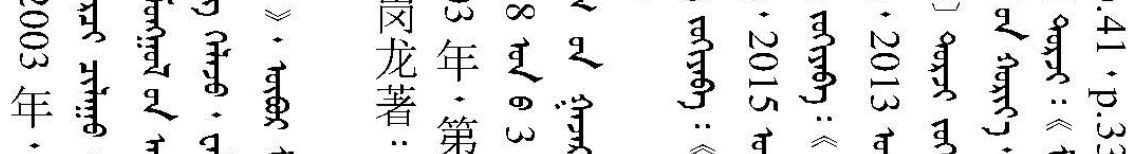

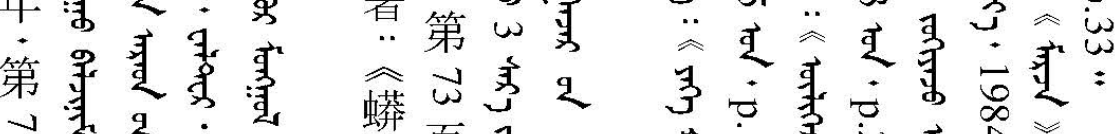

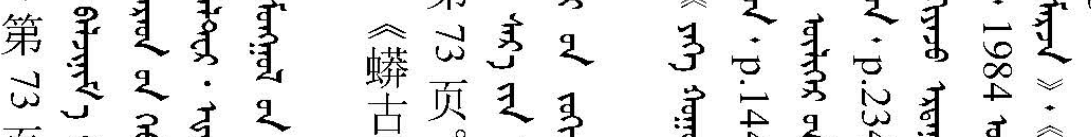

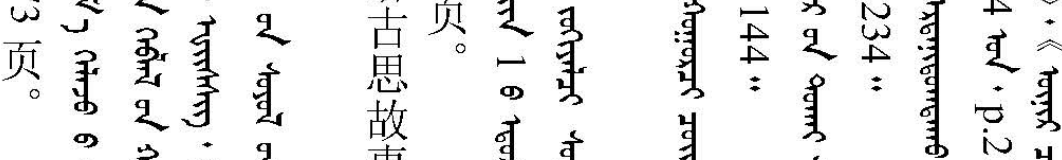

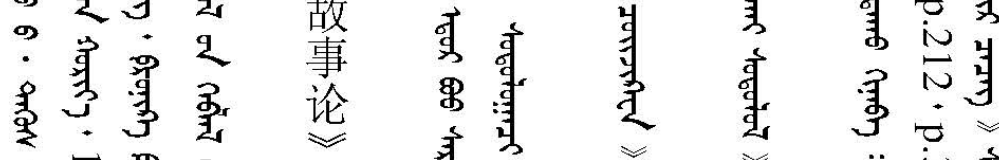

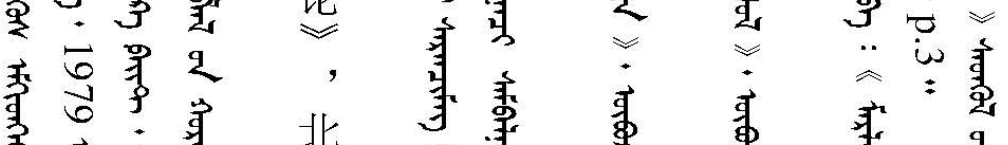

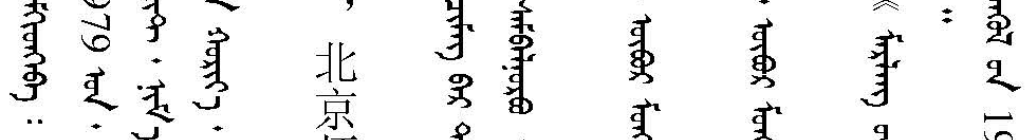

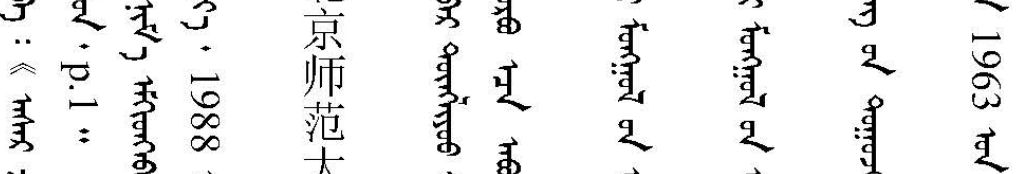

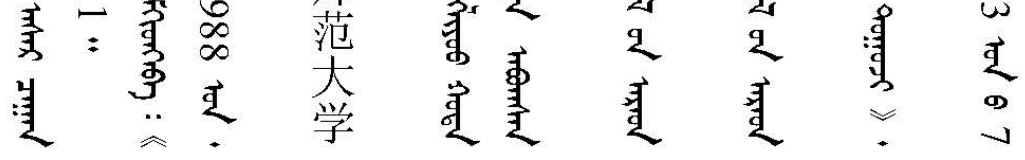

